\title{
8. PETROLOGY AND GEOCHEMISTRY OF BASALTS FROM HOLE 396B, LEG 46
}

\author{
M.F.J. Flower, ${ }^{1,2}$ W. Ohnmacht, ${ }^{1}$ H.-U. Schmincke, ${ }^{1,3}$ I.L. Gibson, ${ }^{4,5}$ P.T. Robinson, ${ }^{6}$ and R. Parker ${ }^{7}$
}

\begin{abstract}
Basalts from the upper 255 meters of the oceanic crust at Site 396B show moderately large variations in petrography, mineralogy, and chemistry. The upper part of the section comprises aphyric basalt with rare, rounded plagioclase phenocrysts and lesser amounts of olivine. The central part of the section is olivine and plagioclase phyric with modal abundances ranging from about 10 to 30 per cent. The lowest part of the sequence is moderately phyric with widely varying abundances of olivine and plagioclase phenocrysts. Clinopyroxene phenocrysts occur in only one rock. Co-existing olivine and plagioclase phenocrysts exhibit both normal and reverse zoning which suggests mixing of different magma batches prior to eruption.

Major and trace element compositions of glass and whole rock basalt samples from Hole $396 \mathrm{~B}$ suggest the following:

a) The two major basaltic magma types are a Ti-poor, Ca-rich (" $\mathrm{X}$ ") type and Ti-rich, Ca-poor ("Y") type.

b) Different magma batches may represent separate fractions of the same differentiating parent liquid, or may reflect fractionation "events" acting upon similar or distinct liquid compositions. In either case, eruptive products of any one batch show a characteristic chemistry and lithology.

c) Different magma batches appear to have been erupted in a contiguous time sequence except for minor amounts of extreme differentiates interlayered with lavas from unrelated batches. However, eruption of different batches deriving from a single liquid type may be separated by relatively large time intervals.

d) " $\mathrm{X}$ "-type and " $Y$ "'-type liquids are characterized by different low pressure crystal-liquid phase equilibria. Plagioclase apparently precipitated at higher temperatures compared to olivine and clinopyroxene, for equivalent $\mathrm{MgO}$ content in " $\mathrm{X}$ "-type than in " $Y$ "-type liquids.

e) Leg 46 basalts generally have higher $\mathrm{Na}, \mathrm{Ti}$, and large ion lithophile (LIL) element abundances for equivalent $\mathrm{MgO}$ content than basaltic magmas from other parts of the Mid-Atlantic Ridge (e.g., FAMOUS). We tentatively suggest that these differences reflect lower degrees of partial melting at $22^{\circ} \mathrm{N}$ and are a reflection of ambient geothermal conditions.
\end{abstract}

\section{INTRODUCTION}

Leg 46 of the Deep Sea Drilling Project drilled basaltic basement to a depth of 255 meters at Site 396, located at

\footnotetext{
'Inst. für Mineralogie der Ruhr-Universität, 463 Bochum, W. Germany. ${ }^{2}$ Also at Imperial College, London, SW7 2BP, U.K.

${ }^{3}$ On leave at Department of Geological Sciences, University of California, Santa Barbara, California U.S.A.

${ }^{4}$ Department of Geology, Bedford College, London, NWI, U.K

${ }^{5}$ On leave at Department of Geology, Dalhousie University, Halifax, Nova Scotia, Canada.

${ }^{6}$ Department of Earth Sciences, University of California, Riverside, California U.S.A.

'Department of Geology, Imperial College, London, SW7 2BP, U.K.
}

$22^{\circ} 59.14^{\prime} \mathrm{N}$ and $43^{\circ} 30.90^{\prime} \mathrm{W}$ about $150 \mathrm{~km}$ east of the axial part of the Mid-Atlantic Ridge (Figure 1). Shipboard studies of the drilled rocks showed significant variations in petrography, mineralogy, and chemical composition; several distinct lithological, chemical, and magnetic units were defined.

We have undertaken a petrographic, mineralogical, and chemical study of selected rocks from the entire stratigraphic section in order to: (1) study the modal and chemical composition of phenocryst phases; (2) identify and characterize compositional groups from glass and whole rock chemical compositions; (3) determine the relationship between whole rock and glass chemistry and the nature and extent of chemical differentiation; (4) study the relation in time of cogenetic (or unrelated) magmas with physical 


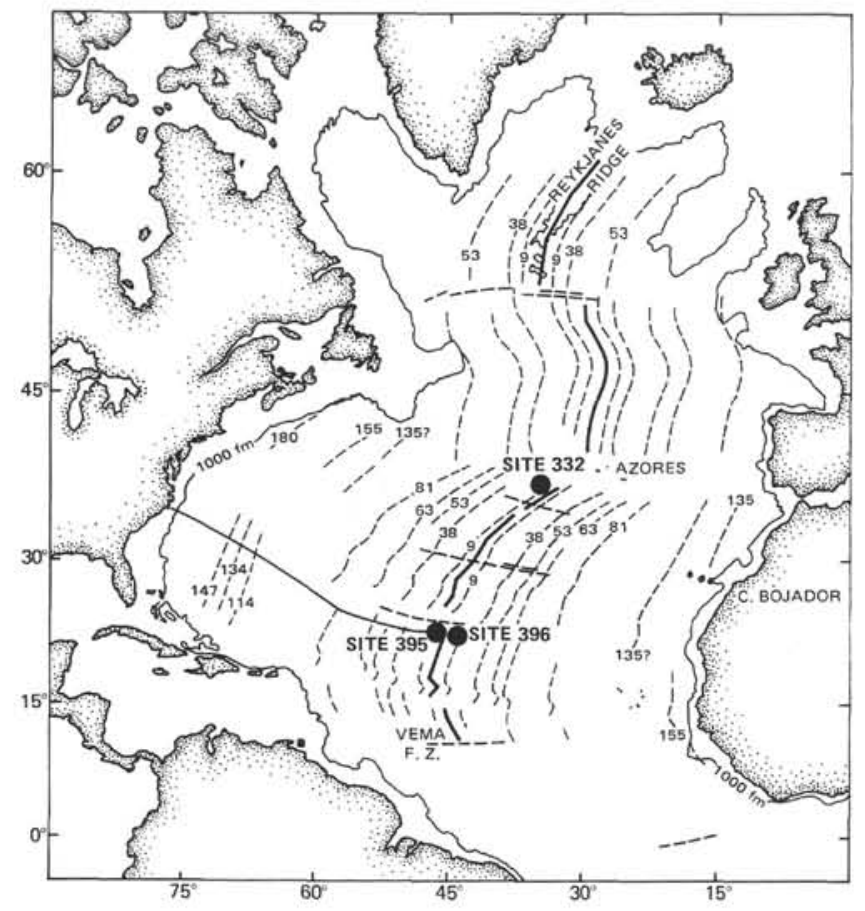

Figure 1. Location map showing Sites 395 and 396 on the Mid-Atlantic Ridge at $22^{\circ} \mathrm{N}$, in comparison with Leg 37, Site 332.

characteristics such as magnetic polarity in order to develop constraints on the eruptive, tectonic, and geothermal processes operating at the rift.

Throughout this report, we refer to the analyzed specimens by their Bochum computer file numbers. These Bochum sample numbers are cross-referenced to respective DSDP numbers and approximate sub-bottom depths in Table 1 . Thirty microprobe analyses of glassy cooling rinds of pillows, sideromelane breccias, and hyaloclastites are given in Table 2; about 40 analyses for major and trace elements are given in Tables 3 and 4. Sixteen specimens were analyzed for rare earth elements (REE), Th, Ta, and Hf (Table 5). About 40 mineral compositions were determined for phenocryst and groundmass phases (Tables 6 through 8), and modal analyses were made for 14 selected specimens (Table 9).

\section{ANALYTICAL TECHNIQUES}

\section{Mineral Analyses}

Analyses were performed with an automatic ARL electron microprobe SEMQ with 6 channels (ETH, Zürich). Acceleration voltage was $15 \mathrm{kv}$, sample current $20 \mathrm{na}$. Kalpha lines were taken for all elements $(\mathrm{Si}, \mathrm{Al}, \mathrm{Fe}, \mathrm{Mg}, \mathrm{Ca}, \mathrm{Na}$, $\mathrm{K}, \mathrm{Ti}, \mathrm{Mn}$, and $\mathrm{Cr}$ ). Standards used were natural clinopyroxene (for $\mathrm{Si}, \mathrm{Mg}$, and $\mathrm{Ca}$ ), garnet ( $\mathrm{Al}$ and $\mathrm{Fe}$ ), labradorite $(\mathrm{Na})$, orthoclase $(\mathrm{K})$, sphene $(\mathrm{Ti})$, chromite $(\mathrm{Cr})$, and a synthetic glass of Mn-garnet composition (Mn). Data reduction was achieved with the aid of program EMMA (ETH, Zürich) which corrects raw microprobe data
TABLE 1

Key to Bochum (lab) Numbers and Methods of Analysis for Samples From Hole 396B

\begin{tabular}{|c|c|c|c|c|}
\hline $\begin{array}{l}\text { Bochum } \\
\text { Sample } \\
\text { No. }\end{array}$ & $\begin{array}{c}\text { Sample } \\
\text { (Interval in } \mathrm{cm} \text { ) } \\
\text { (Piece No. in parentheses) }\end{array}$ & $\begin{array}{l}\text { Sub-basement } \\
\text { Depth }(\mathrm{m})\end{array}$ & Analysis & $\begin{array}{l}\text { Shipboard } \\
\text { Chem. Unit }\end{array}$ \\
\hline $\begin{array}{r}10 \\
20 \\
50 \\
60 \\
70 \\
85 \\
90 \\
110 \\
120 \\
\end{array}$ & $\begin{array}{l}4-1,72-77(6) \\
4-1,80-87(7 \mathrm{~A}) \\
5-2,87-93(9) \\
6-1,87-89(11) \\
7-1,25-30(4) \\
7-1,50-57(7) \\
7-1,60-62(8) \\
7-2,107-113(10) \\
7-2,127-130(12) \\
\end{array}$ & $\begin{array}{r}1.99 \\
2.20 \\
10.99 \\
21.74 \\
24.28 \\
24.50 \\
25.26 \\
30.99 \\
31.56 \\
\end{array}$ & $\begin{array}{l}\text { G } \\
\text { R, G } \\
\text { R, M } \\
\text { G } \\
\text { R } \\
\text { R } \\
\text { R } \\
\text { R } \\
\text { R } \\
\end{array}$ & $A-1$ \\
\hline $\begin{array}{l}140 \\
150 \\
180 \\
210 \\
230 \\
240 \\
260 \\
290 \\
320 \\
\end{array}$ & $\begin{array}{l}8-1,128-135(14 B) \\
8-2,3-7(1) \\
9-1,75-80(10) \\
9-2,125-128(16) \\
10-1,66-68(10) \\
10-1,70-76(11) \\
11-2,27-33(3 \mathrm{~A}) \\
13-1,13-18(2) \\
13-2,28-33(4)\end{array}$ & $\begin{array}{l}38.29 \\
39.26 \\
44.62 \\
50.12 \\
54.33 \\
54.87 \\
63.68 \\
65.53 \\
70.61 \\
\end{array}$ & $\begin{array}{c}\mathrm{R} \\
\mathrm{G}, \mathrm{M} \\
\mathrm{R} \\
\mathrm{G} \\
\mathrm{G} \\
\mathrm{G} \\
\mathrm{R}, \mathrm{M} \\
\mathrm{G} \\
\mathrm{G}\end{array}$ & $A-2$ \\
\hline $\begin{array}{l}400 \\
420 \\
450 \\
470 \\
500 \\
515 \\
520 \\
530 \\
590 \\
600 \\
610\end{array}$ & $\begin{array}{l}14-1,121-127(9) \\
14-2,31-38(4 \mathrm{~A}) \\
14-3,27-33(2) \\
15-1,116-120(12 \mathrm{I}) \\
15-2,111-115(2 \mathrm{~A}) \\
15-2,120-133(2 \mathrm{C}) \\
15-2,141-147(2 \mathrm{I}) \\
15-3,7-15(2 \mathrm{~A}) \\
15-4,132-141(8 \mathrm{~A}) \\
15-5,102-105(13) \\
15-5,108-111(14)\end{array}$ & $\begin{array}{l}77.91 \\
79.12 \\
82.82 \\
86.07 \\
87.99 \\
87.27 \\
88.41 \\
88.64 \\
92.29 \\
93.85 \\
93.93\end{array}$ & $\begin{array}{c}\text { R, G, M } \\
\text { R } \\
\text { R, G } \\
\text { R } \\
\text { M } \\
\text { R } \\
\text { R } \\
\text { R } \\
\text { R } \\
\text { Mo } \\
\text { M }\end{array}$ & A-3 \\
\hline $\begin{array}{c}620 \\
630 \\
690 \\
700 \\
710 \\
730 \\
750 / 760 \\
780 \\
\end{array}$ & $\begin{array}{l}16-1,97-102(10 \mathrm{~F}) \\
16-2,107-113(9) \\
16-4,63-68(8) \\
16-5,34-36(4 \mathrm{~B}) \\
17-1,4-7(1) \\
17-2,43-49(3) \\
17-3,108-112(9) \\
18-1,22-27(2) \\
\end{array}$ & $\begin{array}{r}97.08 \\
102.09 \\
110.02 \\
113.75 \\
117.05 \\
118.99 \\
121.18 \\
122.87 \\
\end{array}$ & $\begin{array}{c}\mathrm{R}, \mathrm{M} \\
\mathrm{R} \\
\mathrm{Mo} \\
\mathrm{R} \\
\mathrm{R}, \mathrm{Mo} \\
\mathrm{R} \\
\mathrm{R}, \mathrm{G}, \mathrm{M} \\
\mathrm{R}, \mathrm{G} \\
\end{array}$ & B-1 \\
\hline $\begin{array}{c}810 \\
840 \\
860 / 870 \\
880 \\
890 \\
910 \\
930 \\
940 \\
970 \\
980 \\
1000 \\
1020 \\
1030 \\
1060 \\
1070 \\
1080 \\
1090 \\
1100 \\
1110 \\
1140 \\
1165 \\
1170 \\
1180 \\
1190 \\
1200 \\
\end{array}$ & $\begin{array}{l}20-1,13-18(1) \\
20-1,35-42(4 \mathrm{~A}) \\
20-1,70-80(4 \mathrm{E}) \\
20-1,131-132(5) \\
20-1,139-141(6) \\
20-2,58-67(5 \mathrm{~B}) \\
20-3,3-10(1) \\
20-3,21-27(3) \\
20-4,6-7(1) \\
20-4,33-39(5) \\
20-4,112-121(12 \mathrm{~F}) \\
20-5,60-68(8) \\
20-6,13-20(2) \\
21-1,3-10(1) \\
21-1,102-110(12 \mathrm{~A}) \\
21-2,43-44(4) \\
22-1,30-38(5) \\
22-1,125-134(14) \\
22-2,8-12(1) \\
22-2,122-144(7 \mathrm{I}) \\
22-3,28-38(2 \mathrm{~A}) \\
22-3,49-56(3 \mathrm{~A}) \\
22-3,92-98(7 \mathrm{~A}) \\
22-4,4-9(1 \mathrm{~A}) \\
22-4,23-26(3)\end{array}$ & $\begin{array}{l}136.18 \\
136.45 \\
136.88 \\
137.54 \\
137.65 \\
138.50 \\
139.61 \\
139.82 \\
141.38 \\
141.73 \\
142.68 \\
143.83 \\
145.04 \\
145.78 \\
150.53 \\
154.67 \\
155.61 \\
157.32 \\
157.88 \\
160.00 \\
160.75 \\
161.34 \\
162.11 \\
163.21 \\
163.37 \\
\end{array}$ & $\begin{array}{c}\text { G } \\
\text { R, Mo } \\
\text { G, M, Mo } \\
\text { G } \\
\text { G, Mo } \\
\text { R, G, M } \\
\text { M } \\
\text { R, Mo } \\
\text { G } \\
\text { G, Mo } \\
\text { G, Mo } \\
\text { R, M, Mo } \\
\text { R, Mo } \\
\text { R, Mo } \\
\text { R } \\
\text { G } \\
\text { R, Mo } \\
\text { R, G, M } \\
\text { R, Mo } \\
\text { Mo } \\
\text { R } \\
\text { R } \\
\text { R, Mo } \\
\text { R } \\
\text { M }\end{array}$ & B-2 \\
\hline $\begin{array}{l}1240 \\
1250 \\
1280 \\
1290 \\
1300 \\
1350\end{array}$ & $\begin{array}{l}24-1,15-16(3) \\
24-1,19-23(4) \\
24-1,88-90(14) \\
25-1,3-5(1) \\
28-1,4-5(1) \\
30-1,84-86(1)\end{array}$ & $\begin{array}{l}175.42 \\
175.99 \\
182.45 \\
186.67 \\
209.87 \\
231.23\end{array}$ & $\begin{array}{c}\mathrm{G} \\
\mathrm{G} \\
\mathrm{G}, \mathrm{M} \\
\mathrm{G} \\
\mathrm{G} \\
\mathrm{G}, \mathrm{M}\end{array}$ & C \\
\hline $\begin{array}{l}1360 \\
1370\end{array}$ & $\begin{array}{l}32-1,11-13(2) \\
32-1,59-62(9)\end{array}$ & $\begin{array}{l}237.09 \\
241.43 \\
\end{array}$ & $\begin{array}{c}\text { R, Mo } \\
\text { R, M, Mo }\end{array}$ & D \\
\hline
\end{tabular}

Note: $\mathrm{R}=$ whole rock chemical composition, $\mathrm{G}=$ glass microprobe composition, $\mathrm{M}=$ mineral microprobe composition, $\mathrm{Mo}=$ modal analysis. 
for absorption, fluorescence by characteristic and continuous radiation, backscatter losses, and ionization-penetration losses. Results are believed to be accurate to about 1 to 2 relative per cent for major elements.

\section{Glass Analyses}

Glass analyses were performed on an automated MAC model 5-SA3 electron microprobe, Division of Geological and Planetary Sciences, California Institute of Technology, Pasadena. Standards and data reduction are based on a program by A.A. Chodos. Sample current for all analyses was $0.01 \mu \mathrm{a}$ and the spot diameter was 30 to $40 \mu \mathrm{m}$. Wherever possible, two or more spots were analyzed for each specimen and the results averaged (Table 2).

\section{Major Element Whole Rock Analyses}

Major elements were determined by X-ray fractionation (XRF) methods using a Phillips PW 1410 under the following conditions:

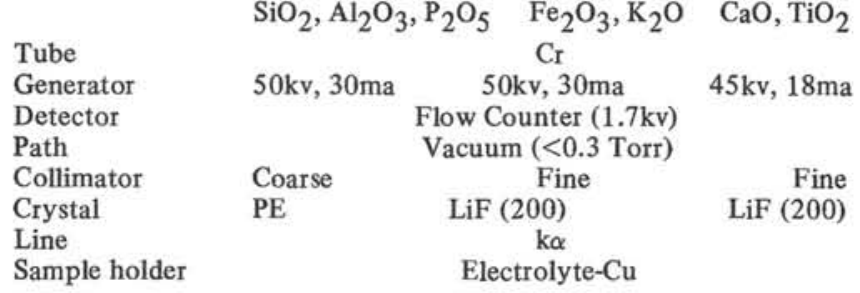

Glass discs were prepared of international standards, Leg 46 standards, and Leg 46 rock powders using the following proportions: 5.15 grams $\mathrm{LiBO}_{2}$ (dried at $550^{\circ} \mathrm{C}, 1 \mathrm{hr}$.); 0.70 grams $\mathrm{La}_{2} \mathrm{O}_{3}$ (dried at $900^{\circ} \mathrm{C}, 1 \mathrm{hr}$.); 1.20 grams rock powder (dried at $1000^{\circ} \mathrm{C}, 2 \mathrm{hr}$.); and 0.05 grams $\mathrm{LiNO}_{3}$. All discs were ground and polished before being analyzed. The raw data were corrected for background and drift. Least-squares calibration curves for each oxide were computed using the data of Abbey (1973), multiplied by loss-on-ignition (LOI) factors. LOI was determined on powders dried at $110^{\circ} \mathrm{C}$ for 24 hours. No corrections were made for Ca-P spectral interferences; however, the error for $P$ is thought to be negligible because unknowns and standards are similar in composition.

Determinations of $\mathrm{FeO}, \mathrm{Na}_{2} \mathrm{O}, \mathrm{MnO}, \mathrm{CO}_{2}$, and $\mathrm{H}_{2} \mathrm{O}$ were done potentiometrically, by AAS, coulorimetric titration (CTA-5 analyzer), and coulorimetric Karl-Fischer-titration (AQUATEST-analyzer). The analytical results for three Leg 46 interlab comparison samples are included in Table 3 as Bochum sample numbers 85, 515, and 1165 (DSDP Samples 396B-7-1, 50-57 cm; $15-2,120-133 \mathrm{~cm}$; and $22-3,28-38 \mathrm{~cm}$; respectively) along with the other major element data.

\section{Trace Element Whole Rock Analyses (XRF)}

The XRF trace element determinations were done on whole rock pressed powder pellets using a Philips 1212 automatic X-ray fluorescence spectrometer. $\mathrm{Sr}, \mathrm{Rb}$, and $\mathrm{Y}$ were analyzed using a Mo X-ray tube, a $\mathrm{LiF}_{220}$ diffraction crystal, and a fine collimator. The remaining trace elements were analyzed using the same diffraction crystal and collimator, and a W X-ray tube. The scintillation and flow proportional counters were used for all elements. The raw data were processed using a modified form of a computer program supplied by B. Gunn. Corrections were made in this program for dead time, matrix effects (using whole rock major element oxide data), line interference, and X-ray tube spectral contamination.

Three standards (W-I, AGV, and BCR) were analyzed with the samples and the values obtained for these standards are listed in Table 4 . This table also lists the values recommended by Flanagan (1973), Abbey (1973), and Willis et al. (1972).

\section{Instrumental Neutron Activation Analyses}

The trace elements ( $\mathrm{Ta}, \mathrm{Hf}$, and $\mathrm{Th})$ and the rare earth elements ( $\mathrm{Ce}, \mathrm{Nd}, \mathrm{Eu}, \mathrm{Tb}, \mathrm{Yb}$, and $\mathrm{Lu}$ ) were determined by instrumental neutron activation analysis (Gordon et al., 1968). Accurately weighed powdered rock samples $(\sim 0.5$ g) were irradiated for 40 hours at a flux of $1 \times 10^{12} \mathrm{n} \mathrm{cm}^{-2}$ $\mathrm{sec}^{-1}$ at the University of London Reactor Center, Silwood Park, Ascot. After a one-week delay to allow for the decay of interfering short-lived activities, the samples were counted using a planar $\mathrm{Ge}(\mathrm{Li}) 1-\mathrm{cm}^{3}$ low energy photon detector with a resolution of $640 \mathrm{ev}$ at $122 \mathrm{kev}$. The gamma spectra were recorded on a 1028 channel multi-channel analyzer. Data reduction was by means of the photopeak method of Routi and Prussin (1969).

U.S. Geological Survey Standards G2, AGV, BCR, W-1, and GSP-1 were used for primary calibration and the Alisa Craig granite, supplied by the Open University, was used as a radiation standard. Results for two determinations of NIM-G (Table 5) give an indication of the accuracy and precision of the method.

\section{LITHOLOGY AND PETROGRAPHY}

Hole 396B penetrated 255 meters into acoustic basement. Recovery averaged about 23 per cent but was much higher in the upper pillowed sequence than in the lower clastic units. Eight lithologic units were defined by the Shipboard Party according to type and abundance of phenocrysts and structural character. Units 1 and 2 are pillow basalts and Unit 3 is a thick flow of very sparsely ( $<2$ modal \%) olivine and plagioclase phyric basalt. Unit 4 is highly plagioclase-olivine-spinel phyric basalt and Unit 5 is sparsely plagioclase-olivine phyric pillow basalt. Units 6 and 8 are composed mostly of uncemented clastic deposits ("hyaloclastite") with a thin interlayered pillow zone (Unit 7). These rocks vary from sparsely to moderately olivine and plagioclase phyric. (The "hyaloclasfite" is discussed in detail by Schmincke et al., this volume.) Modal analyses of representative samples are given in Table 9 and plotted in Figure 2.

Phenocrysts in shipboard chemical Units B-1, B-2, and C make up 15 to 20 volume per cent with a maximum of about 25 per cent, plagioclase being about 5 to 10 times as abundant as olivine. Sparse spinel occurs as inclusions and single phenocrysts in a few samples and clinopyroxene phenocrysts occur in glomerophyric clusters with plagioclase and olivine in one sample only. Groundmass phases are plagioclase, olivine, and clinopyroxene with glass and oxides. Alteration products are common but generally subordinate and comprise smectite, carbonate, and zeolites. Phenocrysts are generally fresh, although olivine is completely altered in 
TABLE 2

Microprobe Analyses (\%) of Basalt Glass, Leg 46, Hole 396B (sample current $0.01 \mu \mathrm{a}$, spot diameter $30-40 \mu \mathrm{m}$ )

\begin{tabular}{|c|c|c|c|c|c|c|c|c|c|c|c|c|c|c|c|c|c|}
\hline Bochum No. & 10 & 20 & 60 & 150 & 210 & 230 & 240 & 290 & 320 & 400 & 450 & 750 & 780 & 810 & 870 & 880 & 890 \\
\hline $\begin{array}{c}\text { Sample } \\
\text { (Interval in cm) } \\
\end{array}$ & $\begin{array}{r}4-1 \\
72-77\end{array}$ & $\begin{array}{c}4-1 \\
80-87\end{array}$ & $\begin{array}{r}6-1 \\
87-89\end{array}$ & $\begin{array}{l}8-2 \\
3-7\end{array}$ & $\begin{array}{c}9-2, \\
125-128\end{array}$ & $\begin{array}{l}10-1 \\
66-68\end{array}$ & $\begin{array}{l}10-1 \\
70-76\end{array}$ & $\begin{array}{l}\text { 13-1, } \\
13-18\end{array}$ & $\begin{array}{l}13-2 \\
28-33\end{array}$ & $\begin{array}{c}14-1 \\
121-127\end{array}$ & $\begin{array}{l}14-3 \\
27-33\end{array}$ & $\begin{array}{c}17-3, \\
108-112\end{array}$ & $\begin{array}{l}18-1 \\
22-27\end{array}$ & $\begin{array}{l}20-1 \\
13-18\end{array}$ & $\begin{array}{l}20-1 \\
70-80 \\
\end{array}$ & $\begin{array}{c}20-1 \\
131-132 \\
\end{array}$ & $\begin{array}{r}20-1 \\
139-141 \\
\end{array}$ \\
\hline $\begin{array}{l}\text { Shipboard } \\
\text { Chem. Unit }\end{array}$ & $A-1$ & A-1 & $A-1$ & $A-2$ & $A-2$ & $A \cdot 2$ & A.2 & $A-2$ & $A-3$ & $A-3$ & $A-3$ & B-1 & B-1 & B-2 & B-2 & B-2 & B-2 \\
\hline Glass Group & $X-1$ & $X-1$ & $X-1$ & $Y-1$ & $\mathrm{Y}-1$ & $\mathrm{Y}-1$ & $Y-1$ & $Y-1$ & $Y-1$ & $Y-1$ & $\mathrm{Y}-2$ & $X-2$ & $X-2$ & $X-2$ & $X-2$ & $x-2$ & $X-2$ \\
\hline $\mathrm{SiO}_{2}$ & 50.85 & 50.58 & 50.44 & 50.99 & 50.48 & 51.14 & 50.92 & 51.09 & 51.05 & 50.35 & 50.18 & 50.61 & 50.62 & 49.81 & 49.83 & 50.04 & 49.52 \\
\hline $\mathrm{TiO}_{2}$ & 1.45 & 1.42 & 1.44 & 1.57 & 1.56 & 1.54 & 1.49 & 1.50 & 1.54 & 1.55 & 1.71 & 1.44 & 1.45 & 1.42 & 1.43 & 1.39 & 1.38 \\
\hline $\mathrm{Al}_{2} \mathrm{O}_{3}$ & 15.01 & 14.95 & 15.15 & 14.99 & 15.47 & 14.93 & 14.78 & 15.79 & 15.25 & 14.98 & 15.24 & 1.5 .28 & 14.82 & 14.81 & 14.95 & 15.65 & 16.31 \\
\hline $\mathrm{FeO}^{*}$ & 8.96 & 9.33 & 9.18 & 9.29 & 9.31 & 9.43 & 9.51 & 9.03 & 9.59 & 9.33 & 10.03 & 9.51 & 9.40 & 9.34 & 9.35 & 9.24 & 9.17 \\
\hline $\mathrm{MnO}$ & 0.24 & 0.16 & 0.17 & 0.15 & 0.18 & 0.16 & 0.21 & 0.20 & 0.18 & 0.14 & 0.16 & 0.13 & 0.16 & 0.20 & 0.16 & 0.18 & 0.19 \\
\hline $\mathrm{MgO}$ & 8.65 & 8.23 & 8.33 & 7.94 & 8.28 & 7.53 & 7.98 & 7.83 & 8.04 & 8.20 & 7.58 & 7.93 & 7.60 & 7.83 & 7.70 & 7.72 & 7.93 \\
\hline $\mathrm{CaO}$ & 11.66 & 11.59 & 11.45 & 11.25 & 11.38 & 11.34 & 11.04 & 10.87 & 11.24 & 11.29 & 10.90 & 11.58 & 11.73 & 11.75 & 11.90 & 11.61 & 11.61 \\
\hline $\mathrm{Na}_{2} \mathrm{O}$ & 2.73 & 2.79 & 2.60 & 2.90 & 3.00 & 2.85 & 2.92 & 2.80 & 2.98 & 2.88 & 3.24 & 2.95 & 2.76 & 2.82 & 2.89 & 2.78 & 2.80 \\
\hline $\mathrm{K}_{2} \mathrm{O}$ & 0.16 & 0.12 & 0.10 & 0.11 & 0.13 & 0.11 & 0.11 & 0.13 & 0.13 & 0.13 & 0.09 & 0.10 & 0.08 & 0.11 & 0.15 & 0.15 & 0.09 \\
\hline $\mathrm{P}_{2} \mathrm{O}_{5}$ & 0.08 & 0.13 & 0.09 & 0.15 & 0.25 & 0.19 & 0.17 & 0.18 & 0.17 & 0.15 & 0.21 & 0.16 & 0.16 & 0.09 & 0.08 & 0.16 & 0.13 \\
\hline $\mathrm{Cr}_{2} \mathrm{O}_{3}$ & - & 0.04 & 0.04 & 0.04 & 0.07 & 0.04 & 0.08 & - & 0.11 & - & - & 0.06 & - & - & 0.05 & 0.04 & - \\
\hline $\mathrm{NiO}$ & - & 0.04 & - & - & - & - & - & - & 0.06 & 0.04 & - & 0.07 & - & - & - & - & - \\
\hline $\mathrm{BaO}$ & - & & - & - & - & 0.08 & 0.25 & 0.25 & - & - & - & - & 0.18 & - & 0.10 & - & - \\
\hline $\mathrm{SO}_{3}$ & 0.13 & 0.13 & 0.10 & 0.09 & 0.17 & 0.11 & 0.14 & 0.08 & 0.10 & 0.14 & 0.14 & 0.09 & 0.13 & 0.11 & 0.14 & 0.17 & 0.12 \\
\hline Total & 99.92 & 99.51 & 99.09 & 99.37 & 100.28 & 99.45 & 99.60 & 99.75 & 100.44 & 99.18 & 99.48 & 99.91 & 99.09 & 98.29 & 98.73 & 99.13 & 99.25 \\
\hline $\begin{array}{l}\text { No. of } \\
\text { Analyses }\end{array}$ & 1 & 2 & 2 & 2 & 1 & 2 & 2 & 1 & 2 & 1 & 2 & 1 & 3 & 3 & 2 & 2 & 1 \\
\hline
\end{tabular}

some samples, particularly in the lower part of shipboard chemical Unit B-2 and the upper part of shipboard chemical Unit C (see also Honnorez et al. this volume). Phenocrysts in many rocks exhibit disequilibrium textural features (Plates 1 through 5). For example, plagioclase phenocrysts in rocks of shipboard chemical Unit A are generally rounded; in more phyric units, both euhedral and highly resorbed plagioclase and olivine phenocrysts co-exist. Vesicles make up as much as 2 per cent of some rocks and, generally, the most phyric rocks also contain the most vesicles. Fresh glass as pillow rinds or clastic shards is common throughout the section.

\section{MINERAL CHEMISTRY}

\section{Olivine}

About 65 analyses of olivine phenocrysts and a few groundmass crystals were made from 17 samples representing all lithologic units. Phenocryst compositions vary from Fo89.6 to Fo85.0. Compositions of groundmass olivine range from Fo86 (Bochum Sample 620; DSDP Sample 396B-16-1, 97-102 cm) to Fo76 (Bochum Sample 500; DSDP Sample 396B-15-2, 111-115 cm). Traces of Ca, $\mathrm{Mn}, \mathrm{Cr}$, and $\mathrm{Ti}$ are present in the structural formulas, but never exceed 0.5 mole per cent (Table 6). Figure 3 shows a plot of Fo content in olivines versus depth. Both normal and reverse zoning occur in some cases within the same rock. Olivines from shipboard chemical Unit B generally have higher Fo contents and a greater compositional range than those from shipboard chemical Units A and C.

\section{Plagioclase}

About 110 analyses of plagioclase phenocrysts and groundmass crystals were made for 17 samples from all lithologic units. Compositional zoning is normal, reverse, or oscillatory (sometimes within the same specimen). Phenocryst compositions range from $\mathrm{An}_{83}$ to $\mathrm{An}_{65}$ and groundmass compositions are between $\mathrm{An}_{65}$ and $\mathrm{An}_{50}$, if $\mathrm{An}$, $\mathrm{Ab}, \mathrm{K}$ feldspar $+\mathrm{Ca}(\mathrm{Mg}, \mathrm{Fe}) \mathrm{Si}_{3} \mathrm{O}_{8}$ components $=100$ per cent. Ca was not computed entirely as anorthite component. Figure 4 shows that the $\mathrm{Ca}(\mathrm{Mg}, \mathrm{Fe}) \mathrm{Si}_{3} \mathrm{O}_{8}$ component is lower for phenocrysts than for groundmass crystals. Within each group, no strong correlation exists: $\mathrm{Ca}(\mathrm{Mg}, \mathrm{Fe}) \mathrm{Si}_{3} \mathrm{O}_{8}$ is approximately constant for varying An content.

In Figure 3, the ranges for $\mathrm{An}$ and $\mathrm{Ca}(\mathrm{Mg}, \mathrm{Fe}) \mathrm{Si}_{3} \mathrm{O}_{8}$ contents of phenocrysts are plotted versus depth. The mean values for both components yield a perfectly symmetrical distribution (i.e., the higher the An-content, the lower the $\mathrm{Ca}(\mathrm{Mg}, \mathrm{Fe}) \mathrm{Si}_{3} \mathrm{O}_{8}$ content $)$, a feature also characteristic of the groundmass crystals. The $\mathrm{K}$-feldspar content never exceeds 0.84 mole per cent for either phenocrysts or groundmass crystals.

\section{Clinopyroxene}

In Bochum Sample 150 (DSDP Sample 396B-8-2, 3-7 $\mathrm{cm})$, a coarse glomerophyric clot of olivine, plagioclase, and clinopyroxene occurs. From core to rim of a clinopyroxene phenocryst, the following compositions (expressed as structural formulae based on 8 oxygens) were found:

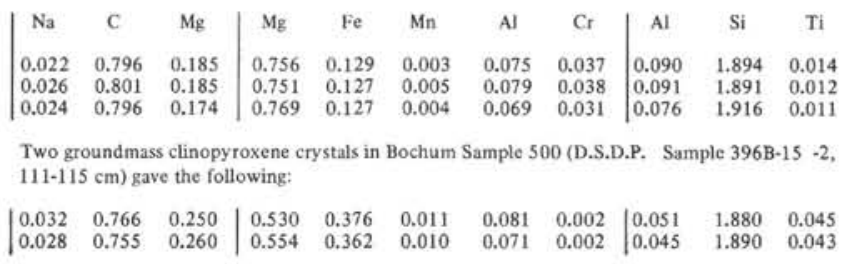

Analyzed crystals are shown in Plates 1 through 5.

\section{MAJOR ELEMENT CHEMISTRY}

\section{Glass}

Fresh glasses representing glassy cooling rinds of pillows, sideromelane breccias, and hyaloclastites were sampled from as many shipboard-defined chemical units as possible (A-1, A-2, A-3, B-1, B-2, and C). Analyses of 30 glass samples are given in Table 2 and plotted with depth in Figure 5. For any 
TABLE 2 - Continued

\begin{tabular}{|c|c|c|c|c|c|c|c|c|c|c|c|c|}
\hline 910 & 970 & 980 & 1000 & 1080 & 1100 & 1240 & 1250 & 1280 & 1290 & 1300 & $1350 \mathrm{a}$ & $1350 \mathrm{~b}$ \\
\hline $\begin{array}{l}20-2, \\
58-67\end{array}$ & $\begin{array}{r}20-4, \\
6-7\end{array}$ & $\begin{array}{l}20-4, \\
33-39\end{array}$ & $\begin{array}{c}20-4, \\
112-121\end{array}$ & $\begin{array}{l}21 \cdot-2, \\
43-44\end{array}$ & $\begin{array}{c}22-1, \\
125-134\end{array}$ & $\begin{array}{l}24-1, \\
15-16\end{array}$ & $\begin{array}{l}24-1 \\
19-23\end{array}$ & $\begin{array}{l}24-1, \\
88-90\end{array}$ & $\begin{array}{c}25-1, \\
3-5\end{array}$ & $\begin{array}{c}28-1, \\
4-5\end{array}$ & \multicolumn{2}{|c|}{$30-1,84-86$} \\
\hline B-2 & B-2 & B-2 & B-2 & B-2 & B-2 & C & C & C & C & C & $\mathrm{C}$ & $\mathrm{C}$ \\
\hline$X-2$ & $x-3$ & $x-3$ & $X-3$ & $X-3$ & $x-3$ & $Y-3$ & $Y-3$ & $Y-3$ & $\mathrm{Y}-3$ & $\mathrm{Y}-3$ & $\mathrm{ZI}$ & $\mathrm{Z} 2$ \\
\hline 50.08 & 50.12 & 50.17 & 50.98 & 49.80 & 49.86 & 49.81 & 50.55 & 49.94 & 49.95 & 50.43 & $49.39+.37$ & $49.63 \pm .40$ \\
\hline 1.37 & 1.27 & 1.26 & 1.30 & 1.29 & 1.24 & 1.52 & 1.56 & 1.59 & 1.57 & 1.53 & $1.52+.01$ & $1.43 \pm .02$ \\
\hline 14.86 & 15.21 & 15.99 & 15.25 & 15.12 & 15.19 & 15.50 & 15.59 & 15.87 & 15.51 & 15.39 & $16.15 \pm .19$ & $16.38 \pm .16$ \\
\hline 9.30 & 8.97 & 8.33 & 8.88 & 9.01 & 8.99 & 9.13 & 8.96 & 8.92 & 9.10 & 9.25 & $9.18 \pm .08$ & $8.90=.10$ \\
\hline 0.17 & 0.16 & 0.13 & 0.16 & 0.15 & 0.17 & 0.15 & 0.17 & 0.21 & 0.16 & 0.16 & $0.15 \pm .04$ & $0.14 \pm .04$ \\
\hline 7.95 & 8.32 & 8.04 & 8.05 & 8.24 & 8.22 & 8.08 & 7.53 & 7.74 & 7.75 & 8.01 & $8.04 \pm .04$ & $8.27 \pm .15$ \\
\hline 11.83 & 11.90 & 11.93 & 11.85 & 12.01 & 12.07 & 11.05 & 11.31 & 11.46 & 11.30 & 11.10 & $11.17 \pm .02$ & $11.38=.06$ \\
\hline 2.89 & 2.96 & 2.67 & 2.78 & 2.66 & 2.73 & 3.12 & 2.97 & 3.05 & 3.01 & 2.84 & $3.08 \pm .02$ & $2.98 \pm .08$ \\
\hline 0.10 & 0.10 & 0.13 & 0.13 & 0.14 & 0.08 & 0.21 & 0.16 & 0.22 & 0.21 & 0.22 & $0.18 \pm .02$ & $0.16 \pm .01$ \\
\hline 0.06 & 0.14 & 0.17 & 0.17 & 0.16 & 0.11 & 0.12 & 0.19 & 0.20 & 0.21 & 0.19 & $0.21 \pm .08$ & $0.20=.04$ \\
\hline 0.10 & 0.05 & - & - & - & 0.10 & - & 0.07 & - & - & 0.09 & $0.06 \pm .02$ & $0.07 \div .03$ \\
\hline- & - & - & - & - & 0.05 & - & - & - & - & 0.07 & - & - \\
\hline 0.17 & - & 0.22 & - & - & 0.13 & - & - & - & - & - & - & - \\
\hline 0.17 & 0.12 & 0.13 & 0.14 & 0.17 & 0.15 & 0.15 & 0.13 & 0.14 & 0.10 & 0.14 & $0.13+.03$ & $0.12 \pm .03$ \\
\hline 99.05 & 99.36 & 99.17 & 99.69 & 98.75 & 99.09 & 98.84 & 99.19 & 99.34 & 98.87 & 99.42 & 99.26 & 99.66 \\
\hline 1 & 2 & 1 & 2 & 1 & 2 & 2 & 2 & 1 & 2 & 1 & 11 & 6 \\
\hline
\end{tabular}

given $\mathrm{MgO}$ content, most variation is shown by $\mathrm{TiO}_{2}$; there is strong positive and negative covariance, respectively, with $\mathrm{FeO}$ and $\mathrm{CaO}$ (Figures 6[a] and 6[b]). Based on $\mathrm{TiO}_{2}$ contents and stratigraphic occurrences, two major glass compositional groupings can be recognized " $\mathrm{X}$ " and " $\mathrm{Y}$ ", types). These are divided into X-1, X-2, X-3, Y-1, Y-2 (one analysis only), and Y-3 subgroups (Figures 6 and 7). A third major glass group (" $\mathrm{Z}$ " type) is recognized in the hyaloclastic unit (Table 2 and Figure 6).

Most oxide contents of Leg 46 glasses range within the spread of data for other regions of the Mid-Atlantic Ridge (e.g., FAMOUS, 36-37 N; Flower et al., 1977a,b) with the exception that $\mathrm{TiO}_{2}$ and $\mathrm{Na} 2 \mathrm{O}$ are distinctly higher, and $\mathrm{CaO}$ is in some cases below the lowest FAMOUS and Leg 37 values for equivalent $\mathrm{MgO}$ content. Normative character (CIPW) of the glasses is typical of MORB compositions of "low-K tholeiite" type, and the parameter An/Di, used by Flower et al. (1977, in press) to distinguish magma variants at Leg 37 drill sites, ranges between about 1.1 and 1.6, which spans the range of Leg 37 and FAMOUS glasses.

Although shipboard-defined chemical "units", were established to represent contiguous stratigraphic intervals, there is clearly the possibility that chemically distinct magma types may be interlayered in places. Moreover, different chemical "units" may relate to the same parent liquid and simply reflect varying degrees of fractionation or accumulation prior to eruption.

The glass analyses in Table 2 are annotated according to glass compositional groups and are related to shipboard chemical units as follows:

\begin{tabular}{|c|c|c|}
\hline $\begin{array}{l}\text { Liquid } \\
\text { Type }\end{array}$ & $\begin{array}{l}\text { Bochum Sample Nos. } \\
\text { (Glass) }\end{array}$ & $\begin{array}{l}\text { Shipboard } \\
\text { "Unit." }\end{array}$ \\
\hline X-1 & $10,20,60$ & A-1 \\
\hline \multirow[t]{2}{*}{$X-2$} & 750,780 & B-1 \\
\hline & $810,870,880,890,910$ & B-2 \\
\hline$X-3$ & $870,980,1000,1080,1100$ & B-2 \\
\hline \multirow[t]{2}{*}{ Y-1 } & $150,210,230,240,290,320$ & A-2 \\
\hline & 400 & A-3? \\
\hline
\end{tabular}

$\begin{array}{lll}\text { Y-2 } & 450 \\ \text { Y-3 } & 1240,1250,1280,1290,1300 & \text { A-3 } \\ \text { Z-1,2 } & 1350 & \text { C }\end{array}$

The stratigraphic distribution of glass (liquid) types $(\mathrm{X}, \mathrm{Y}, \mathrm{Z})$ confirms the difference between A-1 and A-2 shipboard units, although no samples close to the boundary were analyzed (Figure 5). Shipboard Unit A-2 and the upper part of A-3 correspond to our Y-2 glass group, with a single sample (Bochum Sample 450, DSDP Sample 396B-14-3, $27-33 \mathrm{~cm}$ ) from shipboard Unit A-3 corresponding to the $\mathrm{FeO}$ and $\mathrm{TiO}_{2}$-rich Y-2 glass type. No glass samples from the top part of shipboard Unit B-1 were studied, but glasses from the lower part are chemically similar to the top part of shipboard Unit B-2, indicating a compositional hiatus within Core 396B-20.

Glass group Y-3 corresponds to shipboard group C. Glasses from the hyaloclastite in Core 396B-30 (Brochum Sample 1350) appear to represent two chemical groups (Z-1, $\mathrm{Z}-2$ ) somewhat similar to $\mathrm{C}$, but with higher $\mathrm{Al}_{2} \mathrm{O}_{3}$ and $\mathrm{MgO}$, and lower $\mathrm{K}_{2} \mathrm{O}$ and $\mathrm{TiO}_{2}$. More data are being obtained to precisely define chemical glass groups in this interval.

\section{Whole Rock Samples}

To interpret the whole rock chemical data in terms of original magmatic variation, it is necessary to exclude compositions affected by processes of low temperature alteration evidenced by growth of smectite and high contents of $\mathrm{H}_{2} \mathrm{O}^{+}$. The presence of fine carbonate veining in many samples also indicates (approximate) stoichiometric addition of $\mathrm{CaCO}_{3}$ for which correction can be made by subtracting the assumed $\mathrm{CO}_{2}$-related $\mathrm{CaO}$ from the analysis, and normalizing to a $\mathrm{H}_{2} \mathrm{O}^{+}$-free basis.

The main chemical effects of low temperature interaction of basalt with seawater appear to be leaching of $\mathrm{Ca}^{+2}$, oxidation of $\mathrm{Fe}^{+2}$, and addition of $\mathrm{SiO}_{2}$, with other effects (such as $\mathrm{Mg}^{+2}$-leaching and $\mathrm{Fe}$ and $\mathrm{Al}$-enrichment) being associated with more extreme $\mathrm{H}_{2} \mathrm{O}^{+}$-related alteration 
TABLE 3

Major Element Analyses (\%) for Basalts From Hole 396B

\begin{tabular}{|c|c|c|c|c|c|c|c|c|c|c|c|c|c|}
\hline Bochum No. & 20 & 50 & 70 & 85 & 90 & 110 & 120 & 140 & 180 & 210 & 260 & 400 & 840 \\
\hline $\begin{array}{c}\text { Sample } \\
\text { (Interval in } \mathrm{cm} \text { ) }\end{array}$ & $\begin{array}{r}4-1 \\
80-87\end{array}$ & $\begin{array}{r}5-2 \\
87-93\end{array}$ & $\begin{array}{l}7-1 \\
25-30\end{array}$ & $\begin{array}{r}7-1 \\
50-57\end{array}$ & $\begin{array}{l}7-1 \\
60-62\end{array}$ & $\begin{array}{c}7-2 \\
107-113\end{array}$ & $\begin{array}{c}7-2 \\
127-130\end{array}$ & $\begin{array}{c}8-1 \\
128-135\end{array}$ & $\begin{array}{r}9-1 \\
75-80\end{array}$ & $\begin{array}{c}9-2, \\
125-128\end{array}$ & $\begin{array}{l}11-2 \\
27-33\end{array}$ & $\begin{array}{c}14-1, \\
121-127\end{array}$ & $\begin{array}{l}20-1 \\
35-42\end{array}$ \\
\hline $\begin{array}{r}\text { Shipboard } \\
\text { Chem. Unit }\end{array}$ & $A-1$ & A-1 & A-1 & $A-1$ & $A-1$ & $A-1$ & $A-1$ & $A-2$ & A-2 & $A-2$ & $A-2$ & A-3 & B-2 \\
\hline Migma Batch & 1 & 1 & 1 & 1 & 1 & 1 & 1 & 2 & 2 & 2 & 2 & 3 & 4 \\
\hline $\mathrm{SiO}_{2}$ & 49.90 & 49.85 & 49.47 & 49.95 & 49.93 & 49.57 & 49.99 & 49.97 & 49.86 & 49.30 & 49.99 & 49.61 & 49.17 \\
\hline $\mathrm{TiO}_{2}$ & 1.39 & 1.40 & 1.39 & 1.42 & 1.37 & 1.38 & 1.36 & 1.52 & 1.54 & 1.57 & 1.48 & 1.62 & 1.17 \\
\hline $\mathrm{Al}_{2} \mathrm{O}_{3}$ & 15.64 & 15.57 & 15.86 & 15.77 & 15.36 & 15.53 & 15.67 & 15.63 & 15.68 & 15.80 & 15.28 & 15.43 & 17.93 \\
\hline $\mathrm{Fe}_{2} \mathrm{O}_{3}$ & 2.31 & 2.83 & 3.35 & 2.85 & 3.34 & 2.69 & 2.80 & 3.34 & 3.41 & 3.81 & 5.69 & 4.04 & 3.31 \\
\hline $\mathrm{FeO}$ & 7.00 & 6.70 & 6.20 & 6.76 & 5.60 & 6.70 & 6.30 & 6.70 & 6.70 & 6.40 & 4.00 & 5.90 & 5.40 \\
\hline $\mathrm{MnO}$ & 0.16 & 0.16 & 0.17 & 0.17 & 0.15 & 0.17 & 0.16 & 0.18 & 0.18 & 0.18 & 0.16 & 0.16 & 0.15 \\
\hline $\mathrm{MgO}$ & 7.77 & 7.91 & 7.59 & 8.10 & 8.05 & 7.83 & 8.36 & 6.93 & 7.08 & 7.05 & 7.57 & 7.61 & 6.67 \\
\hline $\mathrm{CaO}$ & 11.61 & 11.60 & 11.81 & 12.03 & 11.60 & 11.60 & 11.53 & 11.59 & 11.55 & 11.82 & 11.25 & 11.06 & 12.52 \\
\hline $\mathrm{Na}_{2} \mathrm{O}$ & 2.50 & 2.60 & 2.50 & 2.41 & 2.70 & 2.50 & 2.60 & 2.60 & 2.70 & 2.80 & 2.80 & 2.90 & 2.40 \\
\hline $\mathrm{K}_{2} \mathrm{O}$ & 0.18 & 0.26 & 0.23 & 0.22 & 0.27 & 0.22 & 0.25 & 0.20 & 0.20 & 0.16 & 0.30 & 0.32 & 0.18 \\
\hline $\mathrm{P}_{2} \mathrm{O}_{5}$ & 0.20 & 0.20 & 0.21 & 0.14 & 0.17 & 0.19 & 0.16 & 0.18 & 0.18 & 0.16 & 0.20 & 0.16 & 0.19 \\
\hline $\mathrm{CO}_{2}$ & 0.19 & 0.07 & 0.26 & 0.06 & 0.26 & 0.20 & 0.19 & 0.25 & 0.24 & 0.21 & 0.13 & 0.09 & 0.10 \\
\hline $\mathrm{H}_{2} \mathrm{O}^{+}$ & 1.10 & 0.90 & 1.54 & 0.63 & 0.84 & 1.02 & 1.00 & 1.21 & 1.22 & 1.10 & 1.70 & 1.50 & 1.26 \\
\hline Total & 99.95 & 100.05 & 100.58 & 100.51 & 99.64 & 99.60 & 100.37 & 100.30 & 100.54 & 100.36 & 100.55 & 100.40 & 100.45 \\
\hline $\mathrm{H}_{2} \mathrm{O}^{-}$ & 0.38 & 0.64 & 0.71 & 0.60 & 1.25 & 0.60 & 0.46 & 0.52 & 0.55 & 0.58 & 1.10 & 1.12 & 0.59 \\
\hline L.O.I. & -0.06 & -0.20 & -0.39 & -0.29 & -0.73 & -0.87 & -0.27 & -0.28 & -0.30 & -0.50 & -0.71 & -0.49 & -0.33 \\
\hline
\end{tabular}

reactions (Robinson et al., 1977). We have adopted an empirical value of 1.25 weight per cent $\mathrm{H}_{2} \mathrm{O}^{+}$below which element mobility is taken to be negligible, and accordingly have treated (carbonate-corrected) whole rock analyses by initially projecting their oxide versus $\mathrm{MgO}$ variation in terms of the shipboard chemical units, as for the glass data (Figures $8[a], 8[\mathrm{c}], 9)$. This approach is validated by the overall coherence of whole rock major and trace element chemistry. Despite gross compatibility of $\mathrm{TiO}_{2}, \mathrm{FeO}$, and $\mathrm{Zr}$ abundances with those of the shipboard chemical units, interpretations in terms of plausible petrologic processes are more complex. Chemical groups with common lithologic character are provisionally interpreted as magma batches, with discrete temporal and spatial identities (cf., Leg 37, Flower et al., 1977, in press). Sampling for chemical analysis from shipboard "units" is summarized as follows:

\begin{tabular}{ccc}
$\begin{array}{c}\text { Shipboard } \\
\text { "Unit" No. }\end{array}$ & $\begin{array}{c}\text { Bochum Sample Nos. } \\
\text { (whole rocks) }\end{array}$ & DSDP Sections \\
\hline A-1 & 20 to 120 & $4-1$ to $7-2$ \\
A-2 & 140 to 260 & $8-1$ to $11-2$ \\
A-3 & 420 to 590 & $14-2$ to $15-4$ \\
B-1 & 620 to 780 & $16-1$ to $18-1$ \\
B-2 & 840 to 1190 & $20-1$ to $22-4$ \\
D & 1360,1370 & $32-1$
\end{tabular}

We distinguish whole rock compositional groups based on statistical and graphic examination of the major element oxide data in Figure 8. In the following section, we briefly compare these groups to shipboard chemical units in order to understand the eruptive relations of magma batches.

\section{Shipboard Chemical Groups A-1 to A-3: Lithologic Units I, II, and III: Cores 4-1 to 15-4:}

Aphyric and sparsely olivine + plagioclase phyric pillow basalts from shipboard chemical Units A-1, A-2, and A-3 broadly conform to the chemical characteristics defined on shipboard. We equate them with magma Batches 1, 2, and 3, respectively (Table 3 ), distinguished largely by differences in $\mathrm{TiO}_{2}$. The range of $\mathrm{TiO}_{2}$ content for equivalent $\mathrm{Mg} /(\mathrm{Mg}+$ $\mathrm{Fe}^{+2}$ ) values of the analyzed whole rock samples are summarized as follows:

\begin{tabular}{|c|c|c|c|}
\hline $\begin{array}{l}\text { Batch } \\
\text { No. }\end{array}$ & Chemical Range & $\begin{array}{l}\text { Bochum Sample No. } \\
\text { (whole rocks) }\end{array}$ & $\begin{array}{l}\text { Equivalent } \\
\text { Shipboard } \\
\text { "Unit" }\end{array}$ \\
\hline 1 & $\mathrm{TiO}_{2} 1.36-1.42 \%$ & $\begin{array}{l}20,50,70^{+}, \\
85,90,110,120\end{array}$ & A-1 \\
\hline $\begin{array}{l}2 \\
3\end{array}$ & $\begin{array}{ll}\mathrm{TiO}_{2} & 1.48-1.57 \% \\
\mathrm{TiO}_{2} & 1.60-1.65 \%\end{array}$ & $\begin{array}{l}140,180,210,260^{+} \\
400^{+}, 420^{+}, 450,470^{+} \\
515,520,530^{+}, 590\end{array}$ & $\begin{array}{l}\text { A-2 } \\
\text { A-3 }\end{array}$ \\
\hline
\end{tabular}

$+=$ "altered" sample $\left(>1.25 \% \mathrm{H}_{2} \mathrm{O}^{+}\right)$.

There is no marked compositional gap for $\mathrm{CaO}$ between batches, but this element shows marked overall decrease from Batch 1 to Batch 3 with increasing $\mathrm{TiO}_{2}$ (Figure 10; cf., $\mathrm{Y}-\mathrm{X}$ liquids in Figure 6[b]). The most significant distinction appears to be that of associated glass type, Batch 1 lavas are related to X-1 liquids, whereas Batches 2 and 3 lavas are probably related to Y-1 and Y-2 liquids, respectively (see Figures 8 and $8[b])$.

\section{Shipboard Chemical Groups B-1 and B-2: Lithologic Unit IV: Cores 16-1 to 22-4:}

Eruptive units in this interval are much more phyric (plagioclase $>>$ olivine) than those discussed above (Figure 2). Examination of oxide versus $\mathrm{MgO}$ variation for rocks from shipboard Units " $\mathrm{B}-1$ "' and " $\mathrm{B}-2$ "' confirmed several features noted by the shipboard party: (1) Strong $\mathrm{Al}_{2} \mathrm{O}_{3}$ and $\mathrm{CaO}$ enrichment with decreasing $\mathrm{MgO}$, suggesting plagioclase accumulation which is also compatible with the lithology; (2) B-2 rocks generally have higher $\mathrm{Al}_{2} \mathrm{O}_{3}$ and 
TABLE 3 - Continued

\begin{tabular}{|c|c|c|c|c|c|c|c|c|c|c|c|c|c|}
\hline 1370 & 420 & 450 & 470 & 515 & 520 & 530 & 590 & 620 & 630 & 700 & 710 & 730 & 750 \\
\hline $\begin{array}{l}32-1, \\
59-62 \\
\end{array}$ & $\begin{array}{l}14-2, \\
31-38\end{array}$ & $\begin{array}{l}14-3, \\
27-33\end{array}$ & $\begin{array}{c}15-1, \\
116-120 \\
\end{array}$ & $\begin{array}{c}15-2 \\
120-133 \\
\end{array}$ & $\begin{array}{c}15-2 \\
141-147 \\
\end{array}$ & $\begin{array}{c}15-3, \\
7-15\end{array}$ & $\begin{array}{c}15-4, \\
132-141\end{array}$ & $\begin{array}{l}16-1, \\
97-102\end{array}$ & $\begin{array}{c}16-2, \\
107-113\end{array}$ & $\begin{array}{l}16-5, \\
34-36\end{array}$ & $\begin{array}{c}17-1 \\
4-7\end{array}$ & $\begin{array}{l}17-2 \\
43-49\end{array}$ & $\begin{array}{c}17-3, \\
108-112\end{array}$ \\
\hline D & A- 3 & A-3 & $A-3$ & $A-3$ & A-3 & A-3 & $A-3$ & B-1 & B-1 & B-1 & B-1 & B-1 & B-1 \\
\hline 8 & 3 & 3 & 3 & 3 & 3 & 3 & 3 & 4 & 4 & 4 & 4 & 4 & 4 \\
\hline 49.77 & 49.65 & 49.20 & 49.65 & 49.69 & 49.89 & 49.98 & 49.93 & 48.75 & 49.42 & 49.77 & 49.09 & 49.16 & 49.08 \\
\hline 1.65 & 1.62 & 1.65 & 1.60 & 1.62 & 1.61 & 1.61 & 1.62 & 1.16 & 1.17 & 1.17 & 1.20 & 1.17 & 1.20 \\
\hline 16.21 & 15.22 & 15.85 & 15.20 & 15.26 & 15.16 & 15.19 & 15.54 & 17.28 & 16.40 & 17.06 & 17.27 & 17.34 & 17.69 \\
\hline 3.81 & 4.67 & 3.68 & 4.84 & $3: 32$ & 2.82 & 3.15 & 3.09 & 2.82 & 3.66 & 3.34 & 4.30 & 2.89 & 3.12 \\
\hline 5.20 & 5.50 & 6.70 & 5.30 & 6.92 & 7.20 & 6.50 & 6.70 & 5.60 & 4.60 & 4.80 & 4.70 & 5.70 & 5.60 \\
\hline 0.16 & 0.16 & 0.17 & 0.16 & 0.16 & 0.16 & 0.16 & 0.17 & 0.15 & 0.13 & 0.14 & 0.15 & 0.15 & 0.15 \\
\hline 6.70 & 7.39 & 7.06 & 7.38 & 8.02 & 7.75 & 7.65 & 7.65 & 7.60 & 7.48 & 7.18 & 6.70 & 7.05 & 6.83 \\
\hline 11.85 & 10.90 & 11.06 & 10.81 & 10.95 & 10.81 & 10.84 & 11.05 & 12.16 & 11.84 & 12.02 & 12.40 & 12.33 & 12.47 \\
\hline 2.70 & 2.90 & 2.90 & 3.00 & 2.69 & 2.90 & 2.80 & 2.90 & 2.50 & 2.60 & 2.50 & 2.60 & 2.50 & 2.60 \\
\hline 0.35 & 0.33 & 0.27 & 0.29 & 0.14 & 0.17 & 0.17 & 0.19 & 0.22 & 0.21 & 0.24 & 0.21 & 0.25 & 0.13 \\
\hline 0.24 & 0.23 & 0.21 & 0.21 & 0.15 & 0.22 & 0.21 & 0.17 & 0.17 & 0.17 & 0.15 & 0.13 & 0.17 & 0.10 \\
\hline 0.46 & 0.09 & 0.14 & 0.10 & 0.02 & 0.18 & 0.22 & 0.29 & 0.32 & 0.21 & 0.12 & 0.22 & 0.30 & 0.51 \\
\hline 1.50 & 1.40 & 1.10 & 1.40 & 0.79 & 1.20 & 1.30 & 1.20 & 1.16 & 1.68 & 1.53 & 0.79 & 1.01 & 1.15 \\
\hline 100.60 & 100.06 & 99.99 & 99.94 & 99.73 & 100.07 & 99.78 & 100.05 & 99.89 & 99.57 & 100.02 & 99.76 & 100.02 & 100.63 \\
\hline 1.09 & 1.19 & 0.74 & 1.21 & 1.15 & 0.85 & 1.06 & 0.82 & 0.65 & 1.10 & 1.16 & 1.09 & 0.62 & 0.44 \\
\hline-0.81 & -0.48 & -0.26 & -0.79 & -0.38 & -0.53 & -0.63 & -0.60 & -0.49 & -0.97 & -0.62 & -0.83 & -0.53 & -0.47 \\
\hline
\end{tabular}

$\mathrm{CaO}$ and lower $\mathrm{TiO}_{2}, \mathrm{FeO}$, and $\mathrm{Na}_{2} \mathrm{O}$ for equivalent $\mathrm{MgO}$ contents than B-1 rocks. However, these gross chemical trends are accompanied by additional features that argue against the implicit postulate of two parallel and analogous trends of plagioclase ( \pm olivine \pm clinopyroxene) accumulation, as was demonstrated for Leg 37 rocks (Flower et al., 1977, in press):

1) $\mathrm{Al}_{2} \mathrm{O}_{3}$ and $\mathrm{CaO}$ enrichment trends are accompanied by increases in $\mathrm{TiO}_{2}, \mathrm{FeO}$, and $\mathrm{P}_{2} \mathrm{O}_{5}$, which are incompatible with the cumulate hypothesis in its simplest form;

2) Within each shipboard unit (B-1 and B-2) distinct magma batches are recognized, separated by small but significant $\mathrm{MgO}$ gaps. Also, some $\mathrm{B}-1$ and $\mathrm{B}-2$ analyses overlap for all oxides at a given $\mathrm{MgO}$ or $\mathrm{Mg} /\left(\mathrm{Mg}+\mathrm{Fe}^{+2}\right)$ value.

Hence, we postulate separate magma batches, as for the upper sparsely phyric sequence. These are compatible with trace element data and associated glass compositions and they apparently cross-cut the shipboard B-1/B-2 division, as shown below:

\begin{tabular}{|c|c|c|c|c|}
\hline $\begin{array}{l}\text { Batch } \\
\text { No. }\end{array}$ & $\begin{array}{l}\text { Liquid } \\
\text { (glass) } \\
\text { Type }\end{array}$ & Chemical Range & $\begin{array}{l}\text { Bochum Sample No. } \\
\text { (whole rocks) }\end{array}$ & $\begin{array}{l}\text { Equivalent } \\
\text { Shipboard } \\
\text { "Unit" }\end{array}$ \\
\hline 4 & $X-2$ & $\mathrm{TiO}_{2} 1.61$ to $1.20 \%$ & $\begin{array}{l}620,630^{+}, 700^{+}, \\
710,730,750\end{array}$ & B-1 \\
\hline 5 & $X-1$ & $\mathrm{TiO}_{2} 1.02$ to $1.05 \%$ & $\begin{array}{l}840^{+}, 910 \\
1020^{+}, 1030^{+}, 1060^{+}\end{array}$ & $\begin{array}{l}\text { B-2 } \\
\text { B-2 }\end{array}$ \\
\hline 6 & $?$ & $\mathrm{TiO}_{2} .92$ to $1.03 \%$ & $\begin{array}{l}1070,1090^{+}, 1100^{+}, \\
1110^{+}, 1165,1170^{+}, \\
1180^{+}, 1190\end{array}$ & B-2 \\
\hline
\end{tabular}

Oxide variation (Figures $8[\mathrm{a}]$ and $8[\mathrm{c}]$ ) of these groups suggests that Batches 4 and 5 are related through simple accumulation of plagioclase \pm olivine, as indicated by increases in $\mathrm{Al}_{2} \mathrm{O}_{3}$ content accompanied by increase in
$\mathrm{Mg} /\left(\mathrm{Mg}+\mathrm{Fe}^{+2}\right)$ ratios and decreases in $\mathrm{TiO}_{2}$ and incompatible trace elements (see below). Batch 6, in view of its average $\mathrm{Al}_{2} \mathrm{O}_{3}$ content being lower than that of Batches 4 and 5 , could be tentatively attributed to more extensive accumulation of olivine. However, this is not supported by modal data, and it appears that the significantly higher $\mathrm{Mg} /\left(\mathrm{Mg}+\mathrm{Fe}^{+2}\right)$ ratio of Batch 6 magmas reflects a more primitive character. Batch 6 does not appear to be related to the $\mathrm{X}$ liquid type (the nearest in composition) but probably to a more primitive type for which no glass compositions are known.

Chemical mass balance modeling for the phyric magma batches of whole rock, glass and phenocryst phase compositions, indicates that differentiation of magma batches from any one liquid type is not the result of fractional removal of simple phenocryst phase assemblages, but probably involves interplay of plagioclase accumulation, with accumulation and/or removal of mafic phases and possibly "groundmass" Fe-Ti oxides.

\section{Shipboard Chemical group D: Lithologic Unit VII: Cores 32-1 to 33-1:}

Two samples (Bochum Samples 1360 and 1370; DSDP Samples 396B-32-1, 11-13 cm and 59-62 cm) from the lowermost occurrence of shipboard chemical Group D (i.e., from below the clastic sequence) contrast strongly with each other. Bochum Sample 1360 is of the coarsely (plagioclase $>>$ olivine) phyric shipboard chemical Group B rocks with high $\mathrm{Al}_{2} \mathrm{O}_{3}$ and low $\mathrm{TiO}_{2}(1.28 \%)$, but it does not conform exactly in its major or trace element chemistry to any of the batches $(4,5$, or 6$)$ that are related to X-type or similar liquids, and so must be provisionally regarded as from a distinct batch (7). Bochum Sample 1370, however, is a high $\mathrm{TiO}_{2}(1.68 \%)$ sparsely (olivine + plagioclase) phyric basalt similar to Batch 3 lavas except for higher $\mathrm{Al}_{2} \mathrm{O}_{3}$ content 
TABLE 3 - Continued

\begin{tabular}{|c|c|c|c|c|c|c|c|c|c|c|c|c|c|c|}
\hline Bochum No. & 910 & 940 & 1020 & 1030 & 1060 & 1070 & 1090 & 1100 & 1110 & 1165 & 1170 & 1180 & 1190 & 1360 \\
\hline $\begin{array}{c}\text { Sample } \\
\text { (Interval in } \mathrm{cm} \text { ) } \\
\end{array}$ & $\begin{array}{l}20-2 \\
58-67 \\
\end{array}$ & $\begin{array}{l}20-3 \\
21-27\end{array}$ & $\begin{array}{l}20-5 \\
60-68\end{array}$ & $\begin{array}{l}20-6, \\
13-20\end{array}$ & $\begin{array}{r}21-1 \\
3-10 \\
\end{array}$ & $\begin{array}{c}21-1 \\
102-110\end{array}$ & $\begin{array}{l}22-1, \\
30-38\end{array}$ & $\begin{array}{c}22-1, \\
125-134\end{array}$ & $\begin{array}{r}22-2 \\
8-12 \\
\end{array}$ & $\begin{array}{l}22-3 \\
28-38\end{array}$ & $\begin{array}{l}22-3 \\
49-56\end{array}$ & $\begin{array}{l}22-3, \\
92-98\end{array}$ & $\begin{array}{r}22-4 \\
4-9\end{array}$ & $\begin{array}{l}32-1 \\
11-13 \\
\end{array}$ \\
\hline $\begin{array}{l}\text { Shipboard } \\
\text { Chem. Unit }\end{array}$ & B-2 & B-2 & B-2 & B-2 & B-2 & B-2 & B-2 & B-2 & B-2 & B-2 & B-2 & B-2 & B-2 & D \\
\hline Magma Batch & 4 & 6 & 5 & 5 & 5 & 6 & 6 & 6 & 6 & 6 & 6 & 6 & 6 & 7 \\
\hline $\mathrm{SiO}_{2}$ & 48.63 & 49.52 & 48.36 & 47.96 & 48.42 & 49.76 & 48.54 & 48.95 & 48.57 & 49.06 & 48.76 & 48.90 & 49.55 & 48.76 \\
\hline $\mathrm{TiO}_{2}$ & 1.16 & 1.01 & 1.02 & 1.05 & 1.04 & 0.99 & 0.97 & 0.96 & 0.92 & 0.96 & 0.95 & 1.00 & 0.96 & 1.25 \\
\hline $\mathrm{Al}_{2} \mathrm{O}_{3}$ & 17.85 & 17.48 & 18.84 & 18.86 & 18.33 & 17.27 & 18.24 & 17.67 & 17.76 & 17.79 & 17.39 & 18.00 & 17.41 & 17.63 \\
\hline $\mathrm{Fe}_{2} \mathrm{O}_{3}$ & 3.28 & 2.86 & 3.83 & 4.41 & 4.17 & 2.52 & 3.25 & 2.75 & 2.39 & 3.18 & 2.56 & 2.89 & 1.41 & 3.42 \\
\hline $\mathrm{FeO}$ & 5.40 & 4.60 & 4.10 & 4.20 & 4.10 & 5.20 & 4.50 & 4.70 & 4.90 & 4.73 & 5.10 & 5.20 & 6.10 & 5.00 \\
\hline $\mathrm{MnO}$ & 0.15 & 0.13 & 0.14 & 0.16 & 0.15 & 0.14 & 0.14 & 0.13 & 0.13 & 0.13 & 0.13 & 0.13 & 0.13 & 0.14 \\
\hline $\mathrm{MgO}$ & 7.16 & 7.42 & 5.86 & 6.26 & 6.33 & 8.24 & 7.28 & 7.79 & 8.44 & 8.04 & 8.52 & 7.84 & 8.13 & 6.41 \\
\hline $\mathrm{CaO}$ & 12.57 & 12.34 & 12.47 & 12.39 & 12.26 & 12.15 & 12.31 & 12.40 & 12.04 & 12.34 & 12.10 & 12.36 & 12.15 & 12.20 \\
\hline $\mathrm{Na}_{2} \mathrm{O}$ & 2.50 & 2.50 & 2.60 & 2.50 & 2.60 & 2.30 & 2.40 & 2.40 & 2.40 & 2.28 & 2.30 & 2.40 & 2.50 & 2.80 \\
\hline $\mathrm{K}_{2} \mathrm{O}$ & 0.15 & 0.20 & 0.15 & 0.20 & 0.17 & 0.17 & 0.15 & 0.22 & 0.17 & 0.17 & 0.19 & 0.10 & 0.12 & 0.27 \\
\hline $\mathrm{P}_{2} \mathrm{O}_{5}$ & 0.12 & 0.14 & 0.17 & 0.12 & 0.19 & 0.12 & 0.19 & 0.16 & 0.11 & 0.09 & 0.13 & 0.09 & 0.15 & 0.19 \\
\hline $\mathrm{CO}_{2}$ & 0.14 & 0.16 & 0.26 & 0.22 & 0.20 & 0.11 & 0.12 & 0.25 & 0.11 & 0.03 & 0.14 & 0.09 & 0.18 & 0.32 \\
\hline $\mathrm{H}_{2} \mathrm{O}^{+}$ & 0.86 & 1.56 & 2.53 & 2.30 & 2.66 & 1.24 & 2.21 & 1.91 & 1.66 & 0.80 & 1.60 & 1.59 & 1.15 & 1.05 \\
\hline Total & 99.97 & 99.92 & 100.33 & 100.63 & 100.62 & 100.21 & 100.30 & 100.29 & 99.60 & 99.60 & 99.87 & 100.59 & 99.94 & 99.44 \\
\hline $\mathrm{H}_{2} \mathrm{O}^{-}$ & 0.32 & 0.94 & 1.52 & 1.62 & 1.65 & 0.75 & 1.14 & 0.94 & 0.79 & 1.10 & 0.72 & 1.00 & 0.45 & 0.49 \\
\hline L.O.I. & -0.51 & -0.76 & -1.70 & -1.77 & -1.54 & -0.57 & -1.21 & -1.14 & -1.21 & -0.77 & -1.02 & -0.94 & -0.44 & -0.59 \\
\hline
\end{tabular}

(16.47\%). Based on the high $\mathrm{Al}_{2} \mathrm{O}_{3}$ content (Figure $8[\mathrm{c}]$ ), we suggest it may represent yet another separate batch (9).

\section{TRACE ELEMENT CHEMISTRY}

Magma batches may also be defined in terms of stable ("alteration-resistant") trace element ratios such as $\mathrm{Ti} / \mathrm{Zr}$, $\mathrm{Zr} / \mathrm{Y}$, and $\mathrm{Ce} / \mathrm{Yb}$. Variation of "mobile", elements (such as $\mathrm{Rb}$ and $\mathrm{Ba}$ ), which are known to be "incompatible" during low pressure fractional crystallization or crystal accumulation processes, may also be used to monitor the extent of low temperature alteration and interaction with seawater. All trace element data obtained by XRF are given in Table 4, whereas REE, Th, Ta, and Hf (determined by INAA) are given in Table 5 .

\section{$\mathrm{Zr}, \mathrm{Y}, \mathrm{Sr}$, and $\mathrm{V}$}

Plots of $\mathrm{Ti}, \mathrm{Y}, \mathrm{Sr}$, and $\mathrm{V}$ versus $\mathrm{Zr}$ (Figure 11) confirm the chemically distinct magma batches derived from major element data. These elements are plotted in Figure 11 along with average values for chondrite interelement ratios taken from Wänke et al. (1974). It seems likely that the departure from chondrite values of at least some LIL element ratios in both modern and archaean basaltic melt compositions is closely related to residual phase assemblages that characterize progressive degrees of partial melting, especially in view of the close approach to chondrite ratios shown by advanced (about 60 to $70 \%$ ) komatiitic melts (Nesbit and Sun, 1976), which probably equilibrated with harzburgite or dunite residues.

\section{Ti Versus Zr (Figure 11[a])}

The non-cumulate (aphyric) Batch 1 and cumulate Batches 4,5 , and 6 related to X-type liquids, have chondritic $\mathrm{Ti}-\mathrm{Sr}$ ratios $(\sim 103)$, whereas Batch 3 (Y-type liquid) has a marginally lower ratio of about 92 .

\section{Y Versus Zr (Figure 11[b])}

$\mathrm{Y}$ vs. $\mathrm{Zr}$ variation suggests $\mathrm{X}$-liquid-derived Batches 5 and 6 have an approximately chondritic $\mathrm{Y}-\mathrm{Zr}$ ratio $(\sim 42)$, whereas a progressive decrease in $\mathrm{Y} / \mathrm{Zr}$ occurs from $\mathrm{X}-1$, $\mathrm{X}-4, \mathrm{X}-5$, and $\mathrm{Y}$-derived batches.

\section{Sr Versus Zr (Figure 11[c])}

Aphyric Batch 1 (X-1 liquid) has a $\mathrm{Sr} / \mathrm{Zr}$ ratio lower than chondrite, whereas the coarsely (plagioclase-olivine) phyric Batches 4, 5, and $6 \mathrm{Sr} / \mathrm{Zr}$ ratios approximately equal to (Batch 4), or much greater than (Batches 5 and 6), the chondritic value of about 1.8. A progressive decrease in the $\mathrm{Sr} / \mathrm{Zr}$ ratio is observed from Batch 1 to the sparsely phyric Batches 2 and 3, with increasing $\mathrm{Zr}$ content.

\section{Versus Zr (Figure 11[d])}

Divergence of $\mathrm{V} / \mathrm{Zr}$ ratios in all lavas from chondritic values $(\sim 13)$ is far greater than that of other LIL element ratios, although again, we observe a progressive decrease in magma batches from $X-3(\sim 4.2)$ through to $\mathrm{Y}(\sim 2.6)$.

The solid-liquid partition coefficient $\mathrm{K}_{\mathrm{D}}$ for $\mathrm{Zr}$ in basaltic systems is evidently very low as is that for $\mathrm{Ti}$ where oxide phases are not precipitated. The departure from constant element/ $\mathrm{Zr}$ ratio with increasing $\mathrm{Zr}$ content for $\mathrm{Y}, \mathrm{Sr}$, and $\mathrm{V}$ therefore reflects variable $K_{D}$ values for these elements with respect to solid phases with which liquids were in contact. It is clear that clinopyroxene is not a major component of low pressure fractionation (evidence from petrography and fractionation calculations), suggesting that clinopyroxene remained in the residue during partial melting, with effective 
TABLE 4

Trace Element Data for Leg 46 Rocks and Standards W-1, AGV, and BCR

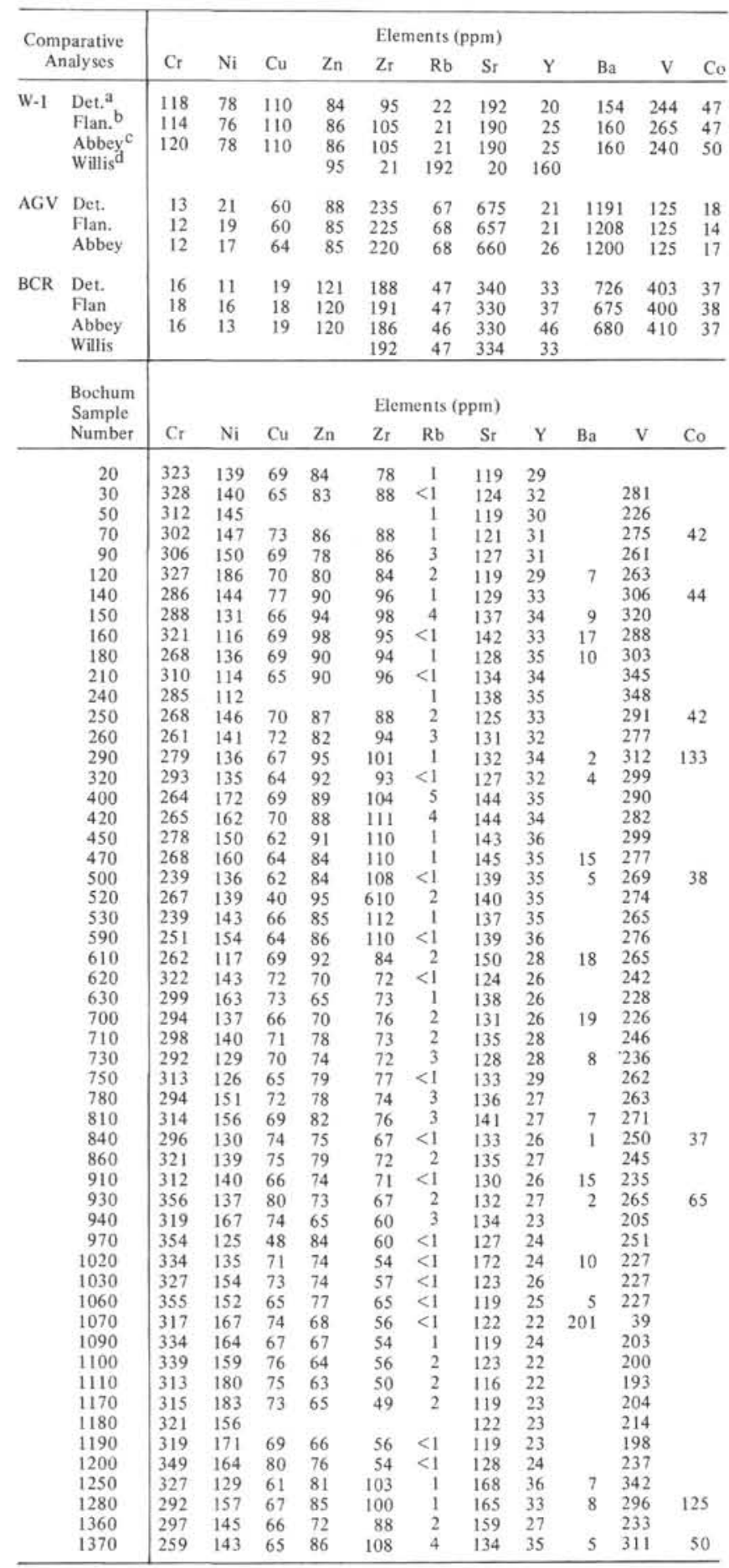

Notes: ${ }^{\text {a }}$ Det. $=$ determined in this work

b Flan. = Flanagan (1973)

Abbey = Abbey (1973)

$\mathrm{d}_{\text {Willis }}=$ Willis et al. $(1972)$

control on both $\mathrm{Y}\left(.5<\mathrm{K}_{\mathrm{D}}{ }^{\mathrm{epx}} 1<1\right)$ and $\mathrm{V}\left(\mathrm{K}_{\mathrm{D}}{ }^{\mathrm{cpx} 1} \approx 1\right.$; Bougault and Hekinian, 1974), at least for those melts that gave rise to X-2, Y-1, and Y-2 liquids. This is probably not a complete explanation, as $\mathrm{Y}-1$ liquid-derived batches have approximately chondritic $\mathrm{Y}-\mathrm{Zr}$ ratios but substantially less than chondritic $\mathrm{V} / \mathrm{Zr}$ ratios.

Similar arguments might be applied to the less than chondritic $\mathrm{Sr} / \mathrm{Zr}$ ratios of aphyric (Batch 1) and sparsely phyric (Batches 2 and 3) lavas in postulating residual plagioclase $\left(\mathrm{K}_{\mathrm{Dp} 1 / 1} \pm 1\right)$ during generation of parental primary liquids. However this is harder to evaluate as the extent of plagioclase removal from these liquids is clearly very variable.

\section{$\mathrm{Cr}, \mathrm{Ni}$, and $\mathrm{Co}$}

The "compatible" trace elements $\left(\mathrm{Kc}^{\mathrm{N}} \mathrm{D}^{\mathrm{s} / 1}>1\right)$ show complex patterns of variation versus $\mathrm{MgO}$ (e.g., Figure 12 showing $\mathrm{Cr}$ versus $\mathrm{MgO}$ ). Any specific magma batch appears to have a characteristic range of $\mathrm{Cr}$ for a given range of $\mathrm{MgO}$, with $\mathrm{Cr} / \mathrm{Mg}$ showing a rough correlation with $\mathrm{Mg} /(\mathrm{Mg}+$ $\mathrm{Fe}^{+2}$ ) ratios. The most probable, and simplest, explanation for the variable $\mathrm{Cr} / \mathrm{Mg}$ character of different magma batches is the variable extent of plagioclase \pm olivine accumulation imposed on the spectrum of parent liquid composition.

\section{Rare Earth Elements (REE), Th, Ta, and Hf}

Sixteen samples representing all shipboard chemical units except $\mathrm{C}$ were analyzed for these elements. The analyses, with chondrite-normalized $\mathrm{Ce} / \mathrm{Yb}$ ratios, identified according to magma batch, are given in Table 5. The chondrite-normalized distribution patterns for $\mathrm{Ce}, \mathrm{Nd}, \mathrm{Eu}$, $\mathrm{Tb}, \mathrm{Yb}$, and Lu are shown in Figure 13 for each magma batch. The REE configurations for each batch are virtually indistinguishable, except for slight positive Eu anomalies in plagioclase-phyric Batches 5, 6, and 7. All patterns are light REE depleted compared to "typical" mid-ocean ridge basalts.

Magma batches are characterized by the sum of REE abundance $\sum \mathrm{Ce}, \mathrm{Nd}, \mathrm{Tb}, \mathrm{Yb}$, and Lu (see Table 5), coarsely phyric lavas having lowest abundances (Figure 13[h]). However, REE abundances in aphyric and sparsely-phyric Batches 1,2, and 3 show an overall inverse correlation with phenocryst abundance (as for Ti and other LIL elements), suggesting higher abundances in $\mathrm{Y}$ than in $\mathrm{X}$-type liquids. The uniformity of $(\mathrm{Ce} / \mathrm{Yb})_{N}$ for all magma types is in striking contrast to the variable patterns of Leg 37 basalts, which correlate with other trace element parameters (e.g., $\mathrm{Zr} / \mathrm{Y}$ ) and with magma types defined from a major element chemistry.

\section{WHOLE ROCK-GLASS RELATIONS}

Certain provisional interpretations of whole rock-glass relations are briefly summarized below:

a) Glass (liquid) compositions are always more $\mathrm{MgO}$-rich and have higher $\mathrm{Mg} /\left(\mathrm{Mg}+\mathrm{Fe}^{+2}\right)$ ratios than the bulk compositions of cooling units with which they are associated. This suggests the likelihood that mafic cumulates (essentially olivine) exist which either were not erupted or simply were not encountered during drilling. Liquid compositions are all evolved compared to likely primary melt compositions. However, the plagioclase-cumulate batch magmas have primitive $\mathrm{Mg} /\left(\mathrm{Mg}+\mathrm{Fe}^{+2}\right)$ ratios in the range of 0.68 to 0.72 . These basalts have no glass equivalents. 
TABLE 5

Rare Earth Elements and Th, Ta, and Hf Concentrations (ppm) of Samples From Hole 396B, and of Standards

\begin{tabular}{|c|c|c|c|c|c|c|c|c|c|c|c|c|c|c|c|c|c|c|c|}
\hline Bochum No. & 70 & 110 & 120 & 140 & 250 & 420 & 450 & 500 & 530 & 560 & 630 & 690 & 840 & 1030 & 1070 & 1370 & & & \\
\hline $\begin{array}{c}\text { Sample } \\
\text { (Interval in cm) } \\
\end{array}$ & $\begin{array}{c}7-1 \\
25-30 \\
\end{array}$ & $\begin{array}{c}7.2 \\
107-113 \\
\end{array}$ & $\begin{array}{c}7-2, \\
127-130\end{array}$ & $\begin{array}{c}8-1, \\
128-135\end{array}$ & $\begin{array}{c}\text { 11-1, } \\
104-108\end{array}$ & $\begin{array}{l}\text { 14-2, } \\
31-38\end{array}$ & $\begin{array}{l}14-3, \\
27-33\end{array}$ & 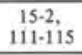 & $\begin{array}{r}15-3, \\
7-15 \\
\end{array}$ & $\begin{array}{l}15-4, \\
13-20\end{array}$ & $\begin{array}{c}16-2, \\
107-113\end{array}$ & $\begin{array}{l}16-4, \\
63-68\end{array}$ & $\begin{array}{l}20-1, \\
35-42\end{array}$ & $\begin{array}{l}20-6, \\
13-20\end{array}$ & $\begin{array}{c}21-1 \\
102-110\end{array}$ & $\begin{array}{l}32-1, \\
59-62\end{array}$ & & & \\
\hline $\begin{array}{c}\text { Shipboard } \\
\text { Chem. Unit } \\
\end{array}$ & A-1 & A-1 & A-1 & A- 2 & $A=2$ & $A-3$ & A-3 & A-3 & A-3 & A-3 & B-1 & B-1 & B-2 & B-2 & B-2 & D & & & \\
\hline Magma Batch & 1 & 1 & 1 & 2 & 2 & 3 & 3 & 3 & 3 & 3 & 4 & 4 & 4 & 6 & 5 & 8 & Standards & NIM-G & NIM-G \\
\hline $\mathrm{Ce}$ & 9.71 & 9.05 & 9.11 & 10.61 & 10.31 & 12.48 & 13.08 & 11.52 & 12.81 & 12.16 & 8.0 & 7.75 & 7.37 & 7.0 & 6.51 & 11.66 & & 208.69 & 212.96 \\
\hline $\mathrm{Nd}$ & 9.46 & 9.21 & 8.58 & 10.51 & 10.44 & 11.89 & 11.08 & 12.03 & 10.88 & 11.67 & 7.44 & 8.37 & 7.33 & 6.94 & 6.65 & 10.87 & & 77.21 & 83.41 \\
\hline $\mathrm{Eu}$ & 1.31 & 1.26 & 1.17 & 1.42 & 1.39 & 1.54 & 1.98 & 1.50 & 1.47 & 1.52 & 1.15 & 1.18 & 1.10 & 1.00 & 1.00 & 1.47 & & 0.36 & 0.33 \\
\hline $\mathrm{Tb}$ & 0.82 & 0.82 & 0.74 & 0.93 & 0.90 & 0.96 & 0.88 & 0.95 & 0.91 & 0.96 & 0.70 & 0.78 & 0.63 & 0.61 & 0.59 & 0.96 & & 2.87 & 2.92 \\
\hline $\mathrm{Yb}$ & 3.38 & 3.24 & 2.99 & 3.76 & 3.52 & 3.65 & 3.25 & 3.82 & 3.65 & 3.8 & 2.57 & 2.89 & 2.58 & 2.43 & 2.28 & 3.77 & & 15.13 & 15.34 \\
\hline $\mathrm{Lu}$ & 0.55 & 0.54 & 0.51 & 0.60 & 0.58 & 0.57 & 0.59 & 0.65 & 0.59 & 0.60 & 0.46 & 0.48 & 0.41 & 0.39 & 0.37 & 0.59 & & 2.14 & 1.76 \\
\hline Th & 0.16 & 0.14 & n.d. & 0.23 & 0.21 & n.d. & n.d. & 0.16 & n.d. & 0.25 & n.d. & 0.18 & 0.16 & n.d. & 0.14 & 0.22 & & 56.45 & 58.36 \\
\hline $\mathrm{Ta}$ & 0.16 & 0.15 & 1.23 & 0.21 & 0.18 & 0.70 & 1.53 & 0.21 & 0.88 & 0.20 & 1.04 & 0.15 & 0.13 & 0.63 & 0.13 & 0.23 & & 4.49 & 4.97 \\
\hline Hf & 2.54 & 2.42 & 2.10 & 2.75 & 2.72 & 3.20 & 1.16 & 2.90 & 3.14 & 2.94 & n.d. & 2.11 & 1,97 & 1.57 & 1.66 & 2.92 & & 12.72 & 13.11 \\
\hline$\left(\mathrm{Yb}_{\mathrm{Yb}}^{\mathrm{Ce}}\right)_{\mathrm{N}}$ & 0.73 & 0.71 & 0.77 & 0.72 & 0.74 & 0.87 & 1.0 & 0.77 & 0.89 & 0.81 & 0.80 & 0.68 & 0.73 & 0.73 & 0.72 & 0.79 & & - & - \\
\hline
\end{tabular}

b) Mass balance solutions for glass-whole rock fractionation, in terms of analyzed phenocrysts $( \pm \mathrm{Fe}-\mathrm{Ti}$ oxides), can in no case be satisfactorily achieved by simple removal or addition of a phase assemblage. Only by postulating the addition of plagioclase and removal of olivine ( \pm clinopyroxene \pm Ti-magnetite) can "daughter" whole-rocks be derived from associated "parent" glass compositions. This suggests that either the fractionation processes in the magma storage region are complex or that other processes, such as magma mixing, have affected magma chemistry.

c) As noted previously, glasses associated with sparsely phyric basalts of Batch 1 (X-2 type) are indistinguishable from those associated with the phyric basalts (up to about $30 \%$ phenocrysts) of Batches 4 and 5 magmas. Intraunit glass-whole rock fractionation in the latter groups is considerably more extensive and distinctive. This must indicate efficient separation of liquid and crystals for any one liquid type so that the liquid fraction in non-cumulate regions of the storage reservoir remains essentially in equilibrium with that in adjacent cumulate regions.

d) There is an important difference in the nature of glass-whole rock fractionation, between X-type and Y-type liquids. Although both $\mathrm{X}$ and $\mathrm{Y}$-type liquids precipitated mafic phases which separated out; $\mathrm{X}$-type liquids gave rise to rocks with higher $\mathrm{Al}_{2} \mathrm{O}_{3}$ and lower $\mathrm{TiO}_{2}$ contents than the parent glass. Y-type liquids resulted in lavas, considerably less phyric, showing a similar but less extensive enrichment of $\mathrm{Al}_{2} \mathrm{O}_{3}$, but higher $\mathrm{TiO}_{2}$ contents than those in the glass. As a preliminary conclusion, we suggest this reflects critical differences in the phase equilibria of $\mathrm{X}$ and $\mathrm{Y}$-type liquids that are responsible for diversification of lithology and chemical fractionation patterns in Leg 46 basalts, and may also reflect differential movement of "groundmass" Ti-magnetite.

\section{SUMMARY}

At least four and probably five magma types were available for eruption during crustal formation at Site 396, each apparently resulting from a specific fractionation event. However, any one eruptive batch of liquid or liquid + crystal mix does not necessarily derive from a single fractionation event. We envisage that magma batches deriving from any one liquid type reflect one or more of several possibilities: (a)
Sampling specific fractions of a magma body differentiating under temporarily closed system conditions. (b) Spatially and/or temporally distinct fractionation events, each characterized by a specific duration, cooling history, and extraction efficiency during an eruptive pulse. (c) An open-ended magmatic system wherein successive magma pulses intrude into and mix with solid and liquid fractionation products of each other. Despite the a priori likelihood of this process, the apparent clustering of both glass and whole rock chemistry and preliminary quantitative interpretations of the variance indicates this could be only a contributing factor.

At this stage of our interpretation, we prefer the first possibility as the dominant influence. Providing that separation of crystal and liquid phases is efficient (i.e., no intra-cumulus "fraction" develops), this represents the simplest explanation of the relation between chemically distinct magma batches and remarkably homogeneous glass compositions. The complex zoning of phenocrysts could be related to a variety of factors and must be reconciled with any final petrogenetic model.

\section{ACKNOWLEDGMENTS}

Our work was supported by grants (Schm 250116) from the Deutsche Forschungsgemeinschaft. We thank V. Trommsdorff for permission to use the microprobe at the Institute für Kristallographie, ETH Zürich, and M. Sammerauer for help in operating the instrument. We also thank A. Albee for permission to use the California Institute of Technology microprobe and A.A. Chodos for his assistance. The manuscript was written while H.U. Schmincke was supported by a stipend from the VW Foundation.

\section{REFERENCES}

Abbey, S., 1973. Studies in "Standard Samples" of silicate rocks and minerals, Geol. Surv. Canada, Paper 73-76.

Bougault, H. and Hekinian, R., 1974. Rift valley in the Atlantic Ocean near $36^{\circ} 51^{\prime} \mathrm{N}$ : petrology and geochemistry of basaltic rocks, Earth Planet. Sci. Lett., v. 27, p.

Flanagan, F.J. 1973. 1972 values for international geochemical reference samples, Geochim. Cosmochim. Acta., v. 37, p. 1189-1200.

Flower, M.F.J., Robinson, P.T., Schmincke, H.-U., and Ohnmacht, W., 1977. Petrology and geochemistry of igneous rocks. In Aumento, F., Melson, W.G., et al., Initial Reports of the Deep Sea Drilling Project, v. 37: Washington (U.S. Government Printing Office), p. 658-680. 
TABLE 6

Structural Formulas (\%) of Leg 46 Olivines on the Basis of 4 Oxygens

\begin{tabular}{|c|c|c|c|c|c|c|c|c|c|c|c|c|c|}
\hline $\begin{array}{c}\text { Bochum } \\
\text { No. }\end{array}$ & Point & $\mathrm{Na}$ & K & $\mathrm{Ca}$ & $\mathrm{Mg}$ & $\mathrm{Fe}^{2+}$ & $\mathrm{Mn}$ & $\mathrm{Cr}$ & $\mathrm{Al}$ & $\mathrm{Ti}$ & $\mathrm{Si}$ & & emarks \\
\hline 50 & $\begin{array}{l}119 \\
120 \\
121 \\
122 \\
\end{array}$ & $\begin{array}{l}0.0 \\
0.0 \\
0.0 \\
0.0\end{array}$ & $\begin{array}{l}\text { tr. } \\
0.0 \\
0.0 \\
0.0 \\
\end{array}$ & $\begin{array}{l}0.007 \\
0.008 \\
0.007 \\
0.008 \\
\end{array}$ & $\begin{array}{l}1.741 \\
1.745 \\
1.747 \\
1.745 \\
\end{array}$ & $\begin{array}{l}0.273 \\
0.273 \\
0.269 \\
0.262 \\
\end{array}$ & $\begin{array}{l}0.004 \\
0.004 \\
0.005 \\
0.004 \\
\end{array}$ & $\begin{array}{l}0.001 \\
0.0 \\
0.0 \\
0.0 \\
\end{array}$ & $\begin{array}{l}0.001 \\
0.0 \\
0.001 \\
0.0 \\
\end{array}$ & $\begin{array}{l}0.0 \\
0.0 \\
0.0 \\
0.0 \\
\end{array}$ & $\begin{array}{l}0.985 \\
0.985 \\
0.985 \\
0.990 \\
\end{array}$ & $\begin{array}{l}\text { Fo } 86.4 \\
\text { Fo } 86.5 \\
\text { Fo } 86.7 \\
\text { Fo } 86.9 \\
\end{array}$ & $\begin{array}{l}\text { Core } \\
\text { Rim }\end{array}$ \\
\hline 150 & $\begin{array}{r}2 \\
4 \\
3 \\
12 \\
\end{array}$ & $\begin{array}{l}0.001 \\
0.0 \\
0.0 \\
0.0 \\
\end{array}$ & $\begin{array}{l}0.0 \\
0.0 \\
0.0 \\
0.0 \\
\end{array}$ & $\begin{array}{l}0.007 \\
0.008 \\
0.008 \\
0.008 \\
\end{array}$ & $\begin{array}{l}1.712 \\
1.700 \\
1.710 \\
1.729 \\
\end{array}$ & $\begin{array}{l}0.283 \\
0.281 \\
0.286 \\
0.269 \\
\end{array}$ & $\begin{array}{l}0.005 \\
0.005 \\
0.005 \\
0.004 \\
\end{array}$ & $\begin{array}{l}0.0 \\
0.002 \\
0.0 \\
0.0 \\
\end{array}$ & $\begin{array}{l}0.0 \\
0.005 \\
0.0 \\
0.0 \\
\end{array}$ & $\begin{array}{l}0.0 \\
0.0 \\
0.0 \\
0.0 \\
\end{array}$ & $\begin{array}{l}0.996 \\
0.998 \\
0.995 \\
0.995 \\
\end{array}$ & $\begin{array}{l}\text { Fo } 85.8 \\
\text { Fo } 85.8 \\
\text { Fo } 85.7 \\
\text { Fo } 86.5 \\
\end{array}$ & $\begin{array}{l}\text { Rim } \\
\text { Rim } \\
\text { Core }\end{array}$ \\
\hline 260 & $\begin{array}{l}16 \\
17 \\
18 \\
19 \\
20 \\
21 \\
25 \\
\end{array}$ & $\begin{array}{l}0.0 \\
0.0 \\
0.0 \\
0.0 \\
0.0 \\
0.001 \\
0.0 \\
\end{array}$ & $\begin{array}{l}0.0 \\
0.0 \\
0.0 \\
0.0 \\
0.0 \\
0.0 \\
0.0 \\
\end{array}$ & $\begin{array}{l}0.008 \\
0.008 \\
0.008 \\
0.007 \\
0.008 \\
0.008 \\
0.008 \\
\end{array}$ & $\begin{array}{l}1.694 \\
1.719 \\
1.692 \\
1.694 \\
1.706 \\
1.716 \\
1.725 \\
\end{array}$ & $\begin{array}{l}0.300 \\
0.298 \\
0.297 \\
0.294 \\
0.287 \\
0.282 \\
0.289 \\
\end{array}$ & $\begin{array}{l}0.005 \\
0.005 \\
0.004 \\
0.005 \\
0.005 \\
0.004 \\
0.005 \\
\end{array}$ & $\begin{array}{l}0.0 \\
0.0 \\
0.0 \\
0.0 \\
0.0 \\
0.0 \\
0.0 \\
\end{array}$ & $\begin{array}{l}0.0 \\
0.0 \\
0.0 \\
0.0 \\
0.0 \\
0.0 \\
0.0 \\
\end{array}$ & $\begin{array}{l}0.0 \\
0.0 \\
0.0 \\
0.0 \\
0.0 \\
0.001 \\
0.0 \\
\end{array}$ & $\begin{array}{l}0.996 \\
0.985 \\
1.000 \\
1.000 \\
0.997 \\
0.994 \\
0.987 \\
\end{array}$ & $\begin{array}{l}\text { Fo } 85.0 \\
\text { Fo } 85.2 \\
\text { Fo } 85.1 \\
\text { Fo } 85.2 \\
\text { Fo } 85.6 \\
\text { Fo } 85.9 \\
\text { Fo } 85.7 \\
\end{array}$ & $\begin{array}{l}\text { Rim } \\
\text { Core } \\
\text { Rim }\end{array}$ \\
\hline 400 & $\begin{array}{l}194 \\
195 \\
196 \\
\end{array}$ & $\begin{array}{l}0.0 \\
0.0 \\
0.0 \\
\end{array}$ & $\begin{array}{l}0.0 \\
0.0 \\
0.0 \\
\end{array}$ & $\begin{array}{l}0.008 \\
0.008 \\
0.008 \\
\end{array}$ & $\begin{array}{l}1.710 \\
1.708 \\
1.720 \\
\end{array}$ & $\begin{array}{l}0.299 \\
0.294 \\
0.296 \\
\end{array}$ & $\begin{array}{l}0.005 \\
0.005 \\
0.004 \\
\end{array}$ & $\begin{array}{l}0.001 \\
0.0 \\
0.0 \\
\end{array}$ & $\begin{array}{l}0.0 \\
0.0 \\
0.0 \\
\end{array}$ & $\begin{array}{l}0.0 \\
0.001 \\
0.0 \\
\end{array}$ & $\begin{array}{l}0.988 \\
0.992 \\
0.986 \\
\end{array}$ & $\begin{array}{l}\text { Fo } 85.1 \\
\text { Fo } 85.3 \\
\text { Fo } 85.3 \\
\end{array}$ & $\begin{array}{l}\text { Core } \\
\text { Core } \\
\text { Core } \\
\end{array}$ \\
\hline 500 & $\begin{array}{l}130 \\
132 \\
\end{array}$ & $\begin{array}{l}0.0 \\
0.0 \\
\end{array}$ & $\begin{array}{l}0.0 \\
0.0 \\
\end{array}$ & $\begin{array}{l}0.009 \\
0.008 \\
\end{array}$ & $\begin{array}{l}1.623 \\
1.510 \\
\end{array}$ & $\begin{array}{l}0.386 \\
0.484 \\
\end{array}$ & $\begin{array}{l}0.006 \\
0.009 \\
\end{array}$ & $\begin{array}{l}0.0 \\
0.0 \\
\end{array}$ & $\begin{array}{l}0.0 \\
0.0 \\
\end{array}$ & $\begin{array}{l}0.0 \\
0.007 \\
\end{array}$ & $\begin{array}{l}0.988 \\
0.987 \\
\end{array}$ & $\begin{array}{l}\text { Fo } 80.8 \\
\text { Fo } 75.7 \\
\end{array}$ & $\begin{array}{l}\text { Groundmass } \\
\text { Groundmass }\end{array}$ \\
\hline 610 & $\begin{array}{l}140 \\
141 \\
\end{array}$ & $\begin{array}{l}0.001 \\
0.0 \\
\end{array}$ & $\begin{array}{l}0.0 \\
0.0 \\
\end{array}$ & $\begin{array}{l}0.008 \\
0.008 \\
\end{array}$ & $\begin{array}{l}1.712 \\
1.719 \\
\end{array}$ & $\begin{array}{l}0.286 \\
0.286 \\
\end{array}$ & $\begin{array}{l}0.005 \\
0.005 \\
\end{array}$ & $\begin{array}{l}0.003 \\
0.0 \\
\end{array}$ & $\begin{array}{l}0.002 \\
0.0 \\
\end{array}$ & $\begin{array}{l}0.002 \\
0.0 \\
\end{array}$ & $\begin{array}{l}0.988 \\
0.991 \\
\end{array}$ & $\begin{array}{l}\text { Fo } 85.7 \\
\text { Fo } 85.7 \\
\end{array}$ & \\
\hline 620 & $\begin{array}{l}16 \\
17 \\
28 \\
29 \\
30 \\
32 \\
\end{array}$ & $\begin{array}{l}0.0 \\
0.0 \\
0.0 \\
0.0 \\
0.0 \\
0.0 \\
\end{array}$ & $\begin{array}{l}0.0 \\
0.0 \\
0.0 \\
0.0 \\
0.0 \\
0.0 \\
\end{array}$ & $\begin{array}{l}0.008 \\
0: 008 \\
0.008 \\
0.008 \\
0.008 \\
0.008 \\
\end{array}$ & $\begin{array}{l}1.773 \\
1.776 \\
1.765 \\
1.772 \\
1.780 \\
1.733 \\
\end{array}$ & $\begin{array}{l}0.249 \\
0.253 \\
0.243 \\
0.242 \\
0.247 \\
0.275 \\
\end{array}$ & $\begin{array}{l}0.004 \\
0.004 \\
0.004 \\
0.004 \\
0.005 \\
0.004 \\
\end{array}$ & $\begin{array}{l}0.001 \\
0.002 \\
0.0 \\
0.0 \\
0.0 \\
0.002 \\
\end{array}$ & $\begin{array}{l}0.0 \\
0.0 \\
0.0 \\
0.0 \\
0.0 \\
0.001 \\
\end{array}$ & $\begin{array}{l}0.0 \\
0.0 \\
0.0 \\
0.0 \\
0.0 \\
0.0 \\
\end{array}$ & $\begin{array}{l}0.982 \\
0.978 \\
0.990 \\
0.987 \\
0.980 \\
0.987 \\
\end{array}$ & $\begin{array}{l}\text { Fo } 87.7 \\
\text { Fo } 87.5 \\
\text { Fo } 87.9 \\
\text { Fo } 88.0 \\
\text { Fo } 87.8 \\
\text { Fo } 86.3 \\
\end{array}$ & $\begin{array}{l}\text { Core } \\
\text { Rim } \\
\text { Core } \\
\text { Rim } \\
\text { Groundmass } \\
\end{array}$ \\
\hline $750 / 760$ & $\begin{array}{l}64 \\
65 \\
66 \\
73 \\
\end{array}$ & $\begin{array}{l}0.0 \\
0.0 \\
0.0 \\
0.0 \\
\end{array}$ & $\begin{array}{l}0.0 \\
0.0 \\
0.0 \\
0.0 \\
\end{array}$ & $\begin{array}{l}0.008 \\
0.008 \\
0.008 \\
0.008 \\
\end{array}$ & $\begin{array}{l}1.749 \\
1.755 \\
1.757 \\
1.759 \\
\end{array}$ & $\begin{array}{l}0.261 \\
0.269 \\
0.252 \\
0.247 \\
\end{array}$ & $\begin{array}{l}0.004 \\
0.004 \\
0.004 \\
0.005 \\
\end{array}$ & $\begin{array}{l}0.0 \\
0.0 \\
0.0 \\
0.002 \\
\end{array}$ & $\begin{array}{l}0.0 \\
0.001 \\
0.001 \\
0.0 \\
\end{array}$ & $\begin{array}{l}0.0 \\
0.001 \\
0.0 \\
0.0 \\
\end{array}$ & $\begin{array}{l}0.988 \\
0.980 \\
0.989 \\
0.989 \\
\end{array}$ & $\begin{array}{l}\text { Fo } 87.0 \\
\text { Fo } 86.7 \\
\text { Fo } 87.5 \\
\text { Fo } 87.7\end{array}$ & $\begin{array}{l}\text { Close to core } \\
\text { Rim }\end{array}$ \\
\hline 810 & $\begin{array}{l}38 \\
39 \\
\end{array}$ & $\begin{array}{l}0.0 \\
0.0 \\
\end{array}$ & $\begin{array}{l}0.0 \\
0.0 \\
\end{array}$ & $\begin{array}{l}0.008 \\
0.008 \\
\end{array}$ & $\begin{array}{l}1.797 \\
1.744 \\
\end{array}$ & $\begin{array}{l}0.211 \\
0.268 \\
\end{array}$ & $\begin{array}{l}0.003 \\
0.004 \\
\end{array}$ & $\begin{array}{l}0.001 \\
0.002 \\
\end{array}$ & $\begin{array}{l}0.0 \\
0.0 \\
\end{array}$ & $\begin{array}{l}0.0 \\
0.0 \\
\end{array}$ & $\begin{array}{l}0.989 \\
0.987 \\
\end{array}$ & $\begin{array}{l}\text { Fo } 89.5 \\
\text { Fo } 86.7 \\
\end{array}$ & \\
\hline $860 / 870$ & $\begin{array}{l}48 \\
49 \\
50 \\
51 \\
52 \\
53 \\
54 \\
55 \\
\end{array}$ & $\begin{array}{l}0.0 \\
0.0 \\
0.0 \\
0.0 \\
0.0 \\
0.0 \\
0.0 \\
0.0 \\
\end{array}$ & $\begin{array}{l}0.0 \\
0.0 \\
0.0 \\
0.0 \\
0.0 \\
0.0 \\
0.0 \\
0.0 \\
\end{array}$ & $\begin{array}{l}0.008 \\
0.008 \\
0.008 \\
0.008 \\
0.008 \\
0.008 \\
0.008 \\
0.008 \\
\end{array}$ & $\begin{array}{l}1.770 \\
1.770 \\
1.737 \\
1.762 \\
1.741 \\
1.744 \\
1.789 \\
1.776 \\
\end{array}$ & $\begin{array}{l}0.247 \\
0.249 \\
0.269 \\
0.248 \\
0.248 \\
0.265 \\
0.227 \\
0.241 \\
\end{array}$ & $\begin{array}{l}0.003 \\
0.003 \\
0.004 \\
0.004 \\
0.003 \\
0.004 \\
0.003 \\
0.003 \\
\end{array}$ & $\begin{array}{l}0.0 \\
0.0 \\
0.0 \\
0.0 \\
0.0 \\
0.0 \\
0.0 \\
0.0 \\
\end{array}$ & $\begin{array}{l}0.001 \\
0.0 \\
0.0 \\
0.0 \\
0.002 \\
0.001 \\
0.003 \\
0.0 \\
\end{array}$ & $\begin{array}{l}0.0 \\
0.0 \\
0.0 \\
0.0 \\
0.0 \\
0.0 \\
0.0 \\
0.0 \\
\end{array}$ & $\begin{array}{l}0.984 \\
0.985 \\
0.991 \\
0.989 \\
0.998 \\
0.989 \\
0.984 \\
0.986 \\
\end{array}$ & $\begin{array}{l}\text { Fo } 87.8 \\
\text { Fo } 87.7 \\
\text { Fo } 86.6 \\
\text { Fo } 87.7 \\
\text { Fo } 87.5 \\
\text { Fo } 86.8 \\
\text { Fo } 88.7 \\
\text { Fo } 88.1 \\
\end{array}$ & $\begin{array}{l}\text { Core } \\
\text { Rim } \\
\text { Close to core } \\
\text { Rim } \\
\text { Core } \\
\text { Rim } \\
\end{array}$ \\
\hline 910 & $\begin{array}{l}206 \\
207 \\
210 \\
\end{array}$ & $\begin{array}{l}0.008 \\
0.0 \\
0.0 \\
\end{array}$ & $\begin{array}{l}0.0 \\
0.0 \\
0.0 \\
\end{array}$ & $\begin{array}{l}0.008 \\
0.008 \\
0.008 \\
\end{array}$ & $\begin{array}{l}1.751 \\
1.769 \\
1.771 \\
\end{array}$ & $\begin{array}{l}0.245 \\
0.245 \\
0.238 \\
\end{array}$ & $\begin{array}{l}0.004 \\
0.004 \\
0.004 \\
\end{array}$ & $\begin{array}{l}0.009 \\
0.001 \\
0.0 \\
\end{array}$ & $\begin{array}{l}0.010 \\
0.0 \\
0.0 \\
\end{array}$ & $\begin{array}{l}0.0 \\
0.0 \\
0.0 \\
\end{array}$ & $\begin{array}{l}0.980 \\
0.986 \\
0.990 \\
\end{array}$ & $\begin{array}{l}\text { Fo } 87.7 \\
\text { Fo } 87.8 \\
\text { Fo } 88.2 \\
\end{array}$ & $\begin{array}{l}\text { Rim } \\
\text { Core }\end{array}$ \\
\hline 930 & $\begin{array}{l}159 \\
160 \\
167 \\
168 \\
169 \\
170 \\
171 \\
172 \\
\end{array}$ & $\begin{array}{l}0.0 \\
0.0 \\
0.006 \\
0.0 \\
0.002 \\
0.0 \\
0.0 \\
0.0 \\
\end{array}$ & $\begin{array}{l}0.0 \\
0.0 \\
0.001 \\
0.0 \\
0.0 \\
0.0 \\
0.0 \\
0.0 \\
\end{array}$ & $\begin{array}{l}0.008 \\
0.008 \\
0.007 \\
0.007 \\
0.008 \\
0.007 \\
0.008 \\
0.007 \\
\end{array}$ & $\begin{array}{l}1.792 \\
1.801 \\
1.786 \\
1.794 \\
1.796 \\
1.762 \\
1.761 \\
1.782 \\
\end{array}$ & $\begin{array}{l}0.223 \\
0.229 \\
0.208 \\
0.211 \\
0.222 \\
0.261 \\
0.258 \\
0.232 \\
\end{array}$ & $\begin{array}{l}0.005 \\
0.004 \\
0.005 \\
0.003 \\
0.004 \\
0.004 \\
0.004 \\
0.004 \\
\end{array}$ & $\begin{array}{l}0.0 \\
0.0 \\
0.008 \\
0.001 \\
0.002 \\
0.0 \\
0.0 \\
0.0 \\
\end{array}$ & $\begin{array}{l}0.0 \\
0.001 \\
0.010 \\
0.001 \\
0.003 \\
0.0 \\
0.001 \\
0.0 \\
\end{array}$ & $\begin{array}{l}0.0 \\
0.0 \\
0.0 \\
0.001 \\
0.0 \\
0.0 \\
0.0 \\
0.0 \\
\end{array}$ & $\begin{array}{l}0.986 \\
0.987 \\
0.982 \\
0.990 \\
0.981 \\
0.983 \\
0.983 \\
0.987 \\
\end{array}$ & $\begin{array}{l}\text { Fo } 88.9 \\
\text { Fo } 88.7 \\
\text { Fo } 89.6 \\
\text { Fo } 89.5 \\
\text { Fo } 89.0 \\
\text { Fo } 87.1 \\
\text { Fo } 87.2 \\
\text { Fo } 88.5 \\
\end{array}$ & $\begin{array}{l}\text { Core } \\
\text { Rim } \\
\text { Core } \\
\text { Rim } \\
\text { Core } \\
\text { Rim } \\
\text { Core } \\
\end{array}$ \\
\hline 1020 & 211 & 0.0 & 0.0 & 0.008 & 1.768 & 0.233 & 0.004 & 0.002 & 0.003 & 0.002 & 0.987 & Fo 88.4 & Inclusion plag \\
\hline 1100 & $\begin{array}{l}187 \\
188 \\
189 \\
190 \\
191 \\
\end{array}$ & $\begin{array}{l}0.001 \\
0.001 \\
0.002 \\
0.0 \\
0.0 \\
\end{array}$ & $\begin{array}{l}0.0 \\
0.0 \\
0.0 \\
0.0 \\
0.0 \\
\end{array}$ & $\begin{array}{l}0.008 \\
0.008 \\
0.007 \\
0.007 \\
0.008 \\
\end{array}$ & $\begin{array}{l}1.777 \\
1.770 \\
1.783 \\
1.766 \\
1.767 \\
\end{array}$ & $\begin{array}{l}0.241 \\
0.240 \\
0.219 \\
0.240 \\
0.238 \\
\end{array}$ & $\begin{array}{l}0.004 \\
0.004 \\
0.004 \\
0.004 \\
0.004 \\
\end{array}$ & $\begin{array}{l}0.002 \\
0.001 \\
0.001 \\
0.0 \\
0.0 \\
\end{array}$ & $\begin{array}{l}0.002 \\
0.0 \\
0.0 \\
0.002 \\
0.0 \\
\end{array}$ & $\begin{array}{l}0.001 \\
0.0 \\
0.0 \\
0.0 \\
0.0 \\
\end{array}$ & $\begin{array}{l}0.981 \\
0.988 \\
0.992 \\
0.990 \\
0.992 \\
\end{array}$ & $\begin{array}{l}\text { Fo } 88.1 \\
\text { Fo } 88.1 \\
\text { Fo } 89.1 \\
\text { Fo } 88.0 \\
\text { Fo } 88.1 \\
\end{array}$ & $\begin{array}{l}\text { Small pheno } \\
\text { Small pheno } \\
\text { Small pheno } \\
\text { Core } \\
\text { Rim }\end{array}$ \\
\hline 1200 & $\begin{array}{l}28 \\
29 \\
40\end{array}$ & $\begin{array}{l}0.0 \\
0.0 \\
0.0\end{array}$ & $\begin{array}{l}0.0 \\
0.0 \\
0.0\end{array}$ & $\begin{array}{l}0.008 \\
0.008 \\
0.009\end{array}$ & $\begin{array}{l}1.781 \\
1.769 \\
1.751 \\
\end{array}$ & $\begin{array}{l}0.225 \\
0.232 \\
0.246 \\
\end{array}$ & $\begin{array}{l}0.004 \\
0.005 \\
0.004 \\
\end{array}$ & $\begin{array}{l}0.001 \\
0.0 \\
0.0 \\
\end{array}$ & $\begin{array}{l}0.001 \\
0.0 \\
0.001\end{array}$ & $\begin{array}{l}0.0 \\
0.0 \\
0.0\end{array}$ & $\begin{array}{l}0.989 \\
0.993 \\
0.994\end{array}$ & $\begin{array}{l}\text { Fo } 88.8 \\
\text { Fo } 88.4 \\
\text { Fo } 87.7\end{array}$ & $\begin{array}{l}\text { Core } \\
\text { Rim }\end{array}$ \\
\hline 1280 & $\begin{array}{l}60 \\
61 \\
62 \\
\end{array}$ & $\begin{array}{l}0.0 \\
0.0 \\
0.0 \\
\end{array}$ & $\begin{array}{l}0.0 \\
0.0 \\
0.0 \\
\end{array}$ & $\begin{array}{l}0.007 \\
0.008 \\
0.008 \\
\end{array}$ & $\begin{array}{l}1.740 \\
1.750 \\
1.748 \\
\end{array}$ & $\begin{array}{l}0.267 \\
0.262 \\
0.263 \\
\end{array}$ & $\begin{array}{l}0.005 \\
0.004 \\
0.004 \\
\end{array}$ & $\begin{array}{l}0.0 \\
0.001 \\
0.002 \\
\end{array}$ & $\begin{array}{l}0.001 \\
0.0 \\
0.002 \\
\end{array}$ & $\begin{array}{l}0.0 \\
0.0 \\
0.001 \\
\end{array}$ & $\begin{array}{l}0.990 \\
0.987 \\
0.984 \\
\end{array}$ & $\begin{array}{l}\text { Fo } 86.7 \\
\text { Fo } 87.0 \\
\text { Fo } 86.9 \\
\end{array}$ & $\begin{array}{l}\text { Core } \\
\text { Rim }\end{array}$ \\
\hline 1370 & $\begin{array}{l}41 \\
43\end{array}$ & $\begin{array}{l}0.0 \\
0.001\end{array}$ & $\begin{array}{l}0.0 \\
0.0\end{array}$ & $\begin{array}{l}0.009 \\
0.008\end{array}$ & $\begin{array}{l}1.718 \\
1.726\end{array}$ & $\begin{array}{l}0.299 \\
0.283\end{array}$ & $\begin{array}{l}0.004 \\
0.004\end{array}$ & $\begin{array}{l}0.0 \\
0.003\end{array}$ & $\begin{array}{l}0.0 \\
0.003\end{array}$ & $\begin{array}{l}0.002 \\
0.001\end{array}$ & $\begin{array}{l}0.983 \\
0.984 \\
\end{array}$ & $\begin{array}{l}\text { Fo } 85.2 \\
\text { Fo } 85.9\end{array}$ & \\
\hline
\end{tabular}


Flower, M.F.J., Robinson, P.T., Schmincke, H.-U., Ohnmacht, W., in press. Magma fractionation systems beneath the Mid-Atlantic Ridge at $36-37^{\circ} \mathrm{N}$, Contrib. Mineral., Petrol.

Gordon, G.E., Randle, K., Goles, G.G., Corliss, J.B., Beeson, M.H., and Oxley, S.S., 1968. Instrumental activation analysis of standard rocks with high resolution X-ray detectors, Geochim. Cosmochim. Acta, v. 32, p. 369-396.

Nesbit, R.W. and Sun, Sh.-S., 1976. Geochemistry of Archaean spinifex-textured peridotites and magnesian and low-magnesian tholeiites, Earth Planet. Sci. Lett., v. 31, p. 433.

Robinson, P.T., Flower, M.F.J., Schmincke, H.-U., and Ohnmacht, W., 1977. Low temperature alteration of oceanic basalts, DSDP Leg. In Aumento, F., Melson, W.G., et al.,
Initial Reports of the Deep Sea Drilling Project, v. 37: Washington (U.S. Government Printing Office), p. 775-794.

Routti, J.T. and Prussin, S.G., 1969. Photopeak method for the computer analysis of $\gamma$-ray spectra from semiconductor detectors, Nucl. Instrum. Methods, v. 72, p. 125-142.

Wänke, H., Baddenhausen, H., Palms, M., and Spettel, B., 1974. On the chemistry of the Allende inclusions and their origin as high temperature condensates, Earth Planet. Sci. Lett., v. 23, p. 1.

Willis, J.P., Erlank, A.J., Gurney, J.J., Theil, R.H., and Ahrens, L.H., 1972. Major, minor and trace element data from some Apollo 11, 12, 14 and 15 samples, Third Lunar Sci. Conf. Proc. Geochim. Cosmochim. Acta, Suppl. 3, v. 2, p. 1269-1273.

TABLE 7

Structural Formulas (\%) of Leg 46 Clinopyroxenes on Basis of 6 Oxygens

\begin{tabular}{cccccccccccc}
\hline $\begin{array}{c}\text { Bochum } \\
\text { No. }\end{array}$ & Point & $\mathrm{Na}$ & $\mathrm{Ca}$ & $\mathrm{Mg}$ & $\mathrm{Fe}^{2+}$ & $\mathrm{Mn}$ & $\mathrm{Al}$ & $\mathrm{Cr}$ & $\mathrm{Ti}$ & $\mathrm{Si}$ & Remarks \\
\hline \multirow{2}{*}{150} & 13 & 0.022 & 0.796 & 0.941 & 0.129 & 0.003 & 0.166 & 0.037 & 0.014 & 1.894 & Core \\
& 14 & 0.026 & 0.801 & 0.936 & 0.127 & 0.005 & 0.170 & 0.038 & 0.012 & 1.891 & \\
& 15 & 0.024 & 0.796 & 0.943 & 0.127 & 0.004 & 0.145 & 0.031 & 0.011 & 1.916 & Rim \\
500 & 129 & 0.032 & 0.766 & 0.780 & 0.376 & 0.011 & 0.132 & 0.002 & 0.045 & 1.880 & Groundmass cryst. \\
& 131 & 0.028 & 0.755 & 0.814 & 0.362 & 0.010 & 0.117 & 0.002 & 0.043 & 1.890 & Groundmass cryst. \\
\hline
\end{tabular}

TABLE 8

Structural Formulas (\%) of Leg 46 Plagioclases Based on 8 Oxygens

\begin{tabular}{|c|c|c|c|c|c|c|c|c|c|c|c|c|}
\hline $\begin{array}{c}\text { Bochum } \\
\text { No. }\end{array}$ & Point & $\mathrm{K}$ & $\mathrm{Na}$ & $\mathrm{Ca}$ & $\mathrm{Mg}$ & $\mathrm{Fe}^{2+}$ & $\mathrm{Mn}$ & $\mathrm{Ti}$ & $\mathrm{Cr}$ & $\mathrm{Al}$ & $\mathrm{Si}$ & Remarks \\
\hline \multirow[t]{6}{*}{50} & 115 & 0.002 & 0.266 & 0.739 & 0.012 & 0.013 & 0.0 & 0.0 & 0.0 & 1.622 & 2.334 & \multirow[t]{6}{*}{ Core } \\
\hline & 116 & 0.002 & 0.271 & 0.755 & 0.015 & 0.014 & 0.0 & 0.0 & 0.0 & 1.636 & 2.313 & \\
\hline & 117 & 0.002 & 0.275 & 0.729 & 0.016 & 0.014 & 0.0 & 0.0 & 0.0 & 1.614 & 2.341 & \\
\hline & 118 & 0.002 & 0.287 & 0.734 & 0.015 & 0.015 & 0.0 & 0.0 & 0.0 & 1.622 & 2.330 & \\
\hline & 123 & 0.002 & 0.332 & 0.675 & 0.031 & 0.036 & 0.0 & 0.0 & 0.0 & 1.531 & 2.398 & \\
\hline & 124 & 0.002 & 0.357 & 0.642 & 0.026 & 0.031 & 0.0 & 0.0 & 0.0 & 1.532 & 2.412 & \\
\hline \multirow[t]{5}{*}{150} & 5 & 0.001 & 0.272 & 0.743 & 0.014 & 0.016 & 0.0 & 0.0 & 0.0 & 1.621 & 2.330 & \multirow[t]{5}{*}{ Rim } \\
\hline & 6 & 0.001 & 0.314 & 0.687 & 0.019 & 0.013 & 0.0 & 0.002 & 0.0 & 1.574 & 2.379 & \\
\hline & 7 & 0.001 & 0.321 & 0.696 & 0.017 & 0.015 & 0.0 & 0.002 & 0.0 & 1.585 & 2.365 & \\
\hline & 8 & 0.002 & 0.311 & 0.710 & 0.016 & 0.014 & 0.0 & 0.0 & 0.0 & 1.614 & 2.341 & \\
\hline & 9 & 0.002 & 0.319 & 0.689 & 0.016 & 0.014 & 0.0 & 0.002 & 0.0 & 1.575 & 2.377 & \\
\hline \multirow[t]{4}{*}{260} & 22 & 0.008 & 0.289 & 0.701 & 0.022 & 0.046 & 0.0 & 0.0 & 0.0 & 1.546 & 2.381 & \multirow{4}{*}{$\begin{array}{l}\text { Later } \\
\text { Groundmass } \\
\text { same point, } \\
\text { different } \\
\text { corrections }\end{array}$} \\
\hline & 23 & 0.004 & 0.379 & 0.616 & 0.028 & 0.039 & 0.0 & 0.014 & 0.0 & 1.489 & 2.432 & \\
\hline & 24.1 & 0.002 & 0.351 & 0.666 & 0.027 & 0.038 & 0.0 & 0.004 & 0.0 & 1.507 & 2.412 & \\
\hline & 24.2 & 0.002 & 0.352 & 0.666 & 0.028 & 0.038 & 0.0 & 0.004 & 0.0 & 1.512 & 2.407 & \\
\hline \multirow[t]{4}{*}{400} & 191 & 0.001 & 0.215 & 0.798 & 0.012 & 0.014 & 0.0 & 0.0 & 0.0 & 1.691 & 2.265 & \multirow[b]{4}{*}{ Grd. M. ( \pm Matrix $) ?$} \\
\hline & 192 & 0.001 & 0.225 & 0.792 & 0.012 & 0.014 & 0.0 & 0.0 & 0.0 & 1.685 & 2.270 & \\
\hline & 193 & 0.001 & 0.192 & 0.831 & 0.013 & 0.016 & 0.0 & 0.0 & 0.0 & 1.729 & 2.225 & \\
\hline & 197 & 0.003 & 0.384 & 0.609 & 0.030 & 0.045 & 0.0 & 0.002 & 0.0 & 1.471 & 2.455 & \\
\hline \multirow[t]{4}{*}{500} & 125 & 0.002 & 0.462 & 0.555 & 0.010 & 0.032 & 0.002 & 0.003 & 0.0 & 1.441 & 2.501 & \multirow{4}{*}{$\begin{array}{l}\text { Groundmass } \\
\text { Groundmass } \\
\text { Groundmass } \\
\text { Groundmass }\end{array}$} \\
\hline & 126 & 0.002 & 0.370 & 0.650 & 0.020 & 0.035 & 0.001 & 0.006 & 0.0 & 1.509 & 2.416 & \\
\hline & 127 & 0.003 & 0.454 & 0.548 & 0.011 & 0.035 & 0.0 & 0.003 & 0.002 & 1.432 & 2.511 & \\
\hline & 128 & 0.002 & 0.424 & 0.602 & 0.016 & 0.026 & 0.0 & 0.003 & 0.002 & 1.481 & 2.456 & \\
\hline \multirow[t]{9}{*}{610} & 133 & 0.0 & 0.227 & 0.784 & 0.017 & 0.015 & 0.0 & 0.0 & 0.0 & 1.675 & 2.279 & \multirow[t]{3}{*}{ Core } \\
\hline & 134 & 0.0 & 0.248 & 0.746 & 0.018 & 0.014 & 0.0 & 0.003 & 0.0 & 1.641 & 2.315 & \\
\hline & 135 & 0.001 & 0.265 & 0.759 & 0.019 & 0.017 & 0.0 & 0.005 & 0.0 & 1.624 & 2.313 & \\
\hline & 136 & 0.001 & 0.250 & 0.753 & 0.017 & 0.017 & 0.0 & 0.001 & 0.0 & 1.652 & 2.303 & \\
\hline & 137 & 0.001 & 0.256 & 0.752 & 0.017 & 0.015 & 0.0 & 0.003 & 0.0 & 1.619 & 2.327 & \\
\hline & 138 & 0.001 & 0.270 & 0.756 & 0.019 & 0.019 & 0.0 & 0.012 & 0.0 & 1.628 & 2.303 & \\
\hline & 139 & 0.001 & 0.257 & 0.753 & 0.017 & 0.015 & 0.0 & 0.002 & 0.0 & 1.632 & 2.317 & Rim \\
\hline & 142 & 0.001 & 0.306 & 0.702 & 0.024 & 0.021 & 0.0 & 0.018 & 0.0 & 1.577 & 2.349 & Small pheno \\
\hline & 143 & 0.001 & 0.300 & 0.712 & 0.019 & 0.021 & 0.0 & 0.001 & 0.00 & 1.584 & 2.359 & Small pheno \\
\hline
\end{tabular}


TABLE 8 - Continued

\begin{tabular}{|c|c|c|c|c|c|c|c|c|c|c|c|c|}
\hline $\begin{array}{l}\text { Bochum } \\
\text { No. }\end{array}$ & Point & $\mathrm{K}$ & $\mathrm{Na}$ & $\mathrm{Ca}$ & $\mathrm{Mg}$ & $\mathrm{Fe}^{2+}$ & $\mathrm{Mn}$ & $\mathrm{Ti}$ & $\mathrm{Cr}$ & $\mathrm{Al}$ & $\mathrm{Si}$ & Remarks \\
\hline & $\begin{array}{l}144 \\
145 \\
148\end{array}$ & $\begin{array}{l}0.001 \\
0.002 \\
0.001\end{array}$ & $\begin{array}{l}0.247 \\
0.244 \\
0.249\end{array}$ & $\begin{array}{l}0.766 \\
0.787 \\
0.756\end{array}$ & $\begin{array}{l}0.017 \\
0.014 \\
0.018\end{array}$ & $\begin{array}{l}0.010 \\
0.010 \\
0.014\end{array}$ & $\begin{array}{l}0.0 \\
0.004 \\
0.0\end{array}$ & $\begin{array}{l}0.0 \\
0.0 \\
0.0\end{array}$ & $\begin{array}{l}0.0 \\
0.013 \\
0.0\end{array}$ & $\begin{array}{l}1.645 \\
1.646 \\
1.643\end{array}$ & $\begin{array}{l}2.307 \\
2.286 \\
2.312\end{array}$ & $\begin{array}{l}\text { Core } \\
\text { Rim } \\
\text { Small pheno }\end{array}$ \\
\hline 620 & $\begin{array}{l}18 \\
19 \\
20 \\
21 \\
22 \\
23 \\
24 \\
25 \\
26 \\
27 \\
31\end{array}$ & $\begin{array}{l}0.001 \\
0.001 \\
0.001 \\
0.001 \\
0.001 \\
0.001 \\
0.0 \\
0.001 \\
0.001 \\
0.0 \\
0.001\end{array}$ & $\begin{array}{l}0.254 \\
0.227 \\
0.202 \\
0.248 \\
0.222 \\
0.263 \\
0.240 \\
0.213 \\
0.192 \\
0.163 \\
0.266\end{array}$ & $\begin{array}{l}0.733 \\
0.775 \\
0.798 \\
0.761 \\
0.795 \\
0.729 \\
0.768 \\
0.795 \\
0.814 \\
0.840 \\
0.739\end{array}$ & $\begin{array}{l}0.019 \\
0.017 \\
0.016 \\
0.019 \\
0.015 \\
0.017 \\
0.015 \\
0.018 \\
0.016 \\
0.016 \\
0.019\end{array}$ & $\begin{array}{l}0.018 \\
0.013 \\
0.011 \\
0.015 \\
0.014 \\
0.015 \\
0.016 \\
0.013 \\
0.013 \\
0.014 \\
0.022\end{array}$ & $\begin{array}{l}0.0 \\
0.001 \\
0.001 \\
0.001 \\
0.002 \\
0.0 \\
0.0 \\
0.0 \\
0.0 \\
0.0 \\
0.0\end{array}$ & $\begin{array}{l}0.002 \\
0.0 \\
0.0 \\
0.0 \\
0.0 \\
0.0 \\
0.0 \\
0.0 \\
0.0 \\
0.0 \\
0.0\end{array}$ & $\begin{array}{l}0.0 \\
0.0 \\
0.0 \\
0.0 \\
0.0 \\
0.0 \\
0.0 \\
0.0 \\
0.0 \\
0.0 \\
0.0\end{array}$ & $\begin{array}{l}1.627 \\
1.685 \\
1.709 \\
1.673 \\
1.698 \\
1.635 \\
1.646 \\
1.707 \\
1.744 \\
1.757 \\
1.618\end{array}$ & $\begin{array}{l}2.330 \\
2.277 \\
2.254 \\
2.284 \\
2.257 \\
2.328 \\
2.306 \\
2.253 \\
2.222 \\
2.207 \\
2.330\end{array}$ & $\begin{array}{l}\text { Rim } \\
\text { Core } \\
\text { Core } \\
\text { Rim } \\
\text { Core } \\
\text { Rim } \\
\text { Core } \\
\text { Rim } \\
\text { Groundmass }\end{array}$ \\
\hline $750 / 760$ & $\begin{array}{l}67 \\
68 \\
69 \\
70 \\
71 \\
72 \\
74 \\
75\end{array}$ & $\begin{array}{l}0.001 \\
0.001 \\
0.001 \\
0.001 \\
0.001 \\
0.002 \\
0.001 \\
0.002\end{array}$ & $\begin{array}{l}0.195 \\
0.164 \\
0.260 \\
0.252 \\
0.263 \\
0.232 \\
0.239 \\
0.300\end{array}$ & $\begin{array}{l}0.803 \\
0.844 \\
0.751 \\
0.761 \\
0.743 \\
0.775 \\
0.760 \\
0.694\end{array}$ & $\begin{array}{l}0.015 \\
0.012 \\
0.015 \\
0.017 \\
0.015 \\
0.014 \\
0.017 \\
0.022\end{array}$ & $\begin{array}{l}0.014 \\
0.015 \\
0.019 \\
0.014 \\
0.013 \\
0.016 \\
0.017 \\
0.028\end{array}$ & $\begin{array}{l}0.0 \\
0.0 \\
0.0 \\
0.0 \\
0.0 \\
0.002 \\
0.0 \\
0.0\end{array}$ & $\begin{array}{l}0.002 \\
0.003 \\
0.003 \\
0.0 \\
0.0 \\
0.0 \\
0.002 \\
0.003\end{array}$ & $\begin{array}{l}0.0 \\
0.0 \\
0.0 \\
0.0 \\
0.0 \\
0.013 \\
0.0 \\
0.0\end{array}$ & $\begin{array}{l}1.709 \\
1.746 \\
1.641 \\
1.650 \\
1.641 \\
1.689 \\
1.667 \\
1.573\end{array}$ & $\begin{array}{l}2.252 \\
2.210 \\
2.310 \\
2.304 \\
2.378 \\
2.261 \\
2.290 \\
2.370\end{array}$ & $\begin{array}{l}\text { Core } \\
\text { Rim } \\
\text { Core } \\
\text { Outermost Rim } \\
\text { Pheno } \\
\text { Groundmass }\end{array}$ \\
\hline 810 & $\begin{array}{l}33 \\
34 \\
35 \\
36 \\
37 \\
40\end{array}$ & $\begin{array}{l}0.0 \\
0.0 \\
0.0 \\
0.0 \\
0.0 \\
0.001\end{array}$ & $\begin{array}{l}0.248 \\
0.241 \\
0.230 \\
0.223 \\
0.189 \\
0.251\end{array}$ & $\begin{array}{l}0.756 \\
0.772 \\
0.773 \\
0.775 \\
0.803 \\
0.760\end{array}$ & $\begin{array}{c}0.016 \\
0.015 \\
0.015 \\
0.091 \\
0.017 \\
0.019\end{array}$ & $\begin{array}{l}0.012 \\
0.014 \\
0.015 \\
0.011 \\
0.013 \\
0.022\end{array}$ & $\begin{array}{l}0.0 \\
0.0 \\
0.0 \\
0.0 \\
0.0 \\
0.0\end{array}$ & $\begin{array}{l}0.0 \\
0.0 \\
0.0 \\
0.0 \\
0.0 \\
0.003\end{array}$ & $\begin{array}{l}0.0 \\
0.0 \\
0.0 \\
0.0 \\
0.0 \\
0.0\end{array}$ & $\begin{array}{l}1.636 \\
1.666 \\
1.688 \\
1.682 \\
1.717 \\
1.640\end{array}$ & $\begin{array}{l}2.319 \\
2.291 \\
2.275 \\
2.280 \\
2.248 \\
2.304\end{array}$ & $\begin{array}{l}\text { Core } \\
\text { Rim } \\
\text { Core } \\
\text { Rim } \\
\text { Minute later }\end{array}$ \\
\hline $860 / 870$ & $\begin{array}{l}42 \\
43 \\
44 \\
42 \\
46 \\
47 \\
56 \\
57 \\
\\
58 \\
59\end{array}$ & $\begin{array}{l}0.0 \\
0.0 \\
0.0 \\
0.0 \\
0.0 \\
0.001 \\
0.0 \\
0.0 \\
\\
0.001 \\
0.001\end{array}$ & $\begin{array}{l}0.151 \\
0.160 \\
0.231 \\
0.178 \\
0.234 \\
0.228 \\
0.187 \\
0.194 \\
0.170 \\
0.258\end{array}$ & $\begin{array}{l}0.864 \\
0.848 \\
0.779 \\
0.828 \\
0.784 \\
0.785 \\
0.824 \\
0.813\end{array}$ & $\begin{array}{l}0.014 \\
0.015 \\
0.017 \\
0.012 \\
0.014 \\
0.016 \\
0.016 \\
0.016 \\
0.015 \\
0.020\end{array}$ & $\begin{array}{l}0.018 \\
0.015 \\
0.015 \\
0.014 \\
0.015 \\
0.017 \\
0.013 \\
0.013 \\
0.019 \\
0.017\end{array}$ & $\begin{array}{l}0.0 \\
0.0 \\
0.0 \\
0.0 \\
0.0 \\
0.0 \\
0.0 \\
0.0 \\
\\
0.0 \\
0.0\end{array}$ & $\begin{array}{l}0.0 \\
0.002 \\
0.0 \\
0.002 \\
0.0 \\
0.0 \\
0.0 \\
0.0\end{array}$ & $\begin{array}{l}0.0 \\
0.0 \\
0.0 \\
0.0 \\
0.0 \\
0.011 \\
0.0 \\
0.0 \\
\\
0.002 \\
0.0\end{array}$ & $\begin{array}{l}1.776 \\
1.759 \\
1.673 \\
1.732 \\
1.682 \\
1.691 \\
1.720 \\
1.730 \\
1.760 \\
1.652\end{array}$ & $\begin{array}{l}2.182 \\
2.200 \\
2.282 \\
2.227 \\
2.274 \\
2.257 \\
2.237 \\
2.233\end{array}$ & $\begin{array}{l}\text { Core } \\
\text { Core } \\
\quad \text { close to } \\
\quad \text { dark incl. } \\
\text { Outermost rim } \\
\text { Small cryst. }\end{array}$ \\
\hline 910 & $\begin{array}{l}198 \\
199 \\
200 \\
202 \\
203 \\
204 \\
205 \\
209\end{array}$ & $\begin{array}{l}0.001 \\
0.001 \\
0.001 \\
0.001 \\
0.001 \\
0.001 \\
0.0 \\
0.001\end{array}$ & $\begin{array}{l}0.187 \\
0.152 \\
0.156 \\
0.255 \\
0.255 \\
0.226 \\
0.195 \\
0.190\end{array}$ & $\begin{array}{l}0.836 \\
0.882 \\
0.870 \\
0.752 \\
0.752 \\
0.788 \\
0.825 \\
0.822\end{array}$ & $\begin{array}{l}0.016 \\
0.012 \\
0.012 \\
0.017 \\
0.016 \\
0.017 \\
0.015 \\
0.016\end{array}$ & $\begin{array}{l}0.015 \\
0.013 \\
0.015 \\
0.014 \\
0.016 \\
0.016 \\
0.013 \\
0.014\end{array}$ & $\begin{array}{l}0.0 \\
0.0 \\
0.0 \\
0.001 \\
0.003 \\
0.0 \\
0.0 \\
0.0\end{array}$ & $\begin{array}{l}0.0 \\
0.002 \\
0.0 \\
0.0 \\
0.0 \\
0.0 \\
0.0 \\
0.0\end{array}$ & $\begin{array}{l}0.0 \\
0.0 \\
0.0 \\
0.003 \\
0.018 \\
0.0 \\
0.002 \\
0.0\end{array}$ & $\begin{array}{l}1.750 \\
1.761 \\
1.756 \\
1.638 \\
1.635 \\
1.704 \\
1.716 \\
1.700\end{array}$ & $\begin{array}{l}2.207 \\
2.185 \\
2.195 \\
2.313 \\
2.303 \\
2.255 \\
2.236 \\
2.252\end{array}$ & $\begin{array}{l}\text { Core } \\
\text { Rim } \\
\text { Core } \\
\text { Rim } \\
\text { Small. } \\
\text { Small } \\
\text { Pheno }\end{array}$ \\
\hline 930 & $\begin{array}{l}161 \\
162 \\
163 \\
164 \\
165 \\
166 \\
173 \\
174\end{array}$ & $\begin{array}{l}0.002 \\
0.001 \\
0.001 \\
0.0 \\
0.0 \\
0.001 \\
0.001\end{array}$ & $\begin{array}{l}0.187 \\
0.175 \\
0.196 \\
0.183 \\
0.171 \\
0.173 \\
0.199\end{array}$ & $\begin{array}{l}0.810 \\
0.828 \\
0.800 \\
0.815 \\
0.813 \\
0.824 \\
0.795\end{array}$ & $\begin{array}{l}0.019 \\
0.018 \\
0.025 \\
0.025 \\
0.017 \\
0.017 \\
0.010\end{array}$ & $\begin{array}{l}0.015 \\
0.012 \\
0.015 \\
0.014 \\
0.012 \\
0.014 \\
0.010\end{array}$ & $\begin{array}{l}0.0 \\
0.0 \\
0.0 \\
0.0 \\
0.0 \\
0.0 \\
0.0\end{array}$ & $\begin{array}{l}0.0 \\
0.0 \\
0.010 \\
0.009 \\
0.0 \\
0.0 \\
0.0\end{array}$ & $\begin{array}{l}0.0 \\
0.0 \\
0.0 \\
0.0 \\
0.0 \\
0.0 \\
0.0\end{array}$ & $\begin{array}{l}1.714 \\
1.734 \\
1.713 \\
1.719 \\
1.742 \\
1.749 \\
1.720\end{array}$ & $\begin{array}{l}2.245 \\
2.227 \\
2.237 \\
2.229 \\
2.230 \\
2.218 \\
2.253\end{array}$ & $\begin{array}{l}\text { Rim } \\
\text { Core } \\
\text { Core } \\
\text { Core } \\
\text { Rim } \\
\text { Core }\end{array}$ \\
\hline & $\begin{array}{l}175 \\
176\end{array}$ & $\begin{array}{l}0.001 \\
0.002\end{array}$ & $\begin{array}{l}0.232 \\
0.321\end{array}$ & $\begin{array}{l}0.756 \\
0.676\end{array}$ & $\begin{array}{l}0.010 \\
0.039\end{array}$ & $\begin{array}{l}0.011 \\
0.046\end{array}$ & $\begin{array}{l}0.0 \\
0.002\end{array}$ & $\begin{array}{l}0.0 \\
0.016\end{array}$ & $\begin{array}{l}0.0 \\
0.002\end{array}$ & $\begin{array}{l}1.687 \\
1.510\end{array}$ & $\begin{array}{l}2.288 \\
2.388\end{array}$ & $\begin{array}{l}\text { Rim } \\
\text { Groundmass }\end{array}$ \\
\hline 1020 & 212 & 0.0 & 0.168 & 0.843 & 0.017 & 0.013 & 0.0 & 0.006 & 0.0 & 1.748 & 2.204 & Pheno \\
\hline 1100 & $\begin{array}{l}178 \\
179 \\
180 \\
181 \\
182 \\
183 \\
184 \\
185 \\
186 \\
\end{array}$ & $\begin{array}{l}0.001 \\
0.001 \\
0.0 \\
0.001 \\
0.001 \\
0.001 \\
0.001 \\
0.001 \\
0.001 \\
\end{array}$ & $\begin{array}{l}0.257 \\
0.263 \\
0.189 \\
0.201 \\
0.172 \\
0.185 \\
0.157 \\
0.225 \\
0.231 \\
\end{array}$ & $\begin{array}{l}0.725 \\
0.734 \\
0.801 \\
0.791 \\
0.821 \\
0.824 \\
0.826 \\
0.764 \\
0.762 \\
\end{array}$ & $\begin{array}{l}0.017 \\
0.020 \\
0.016 \\
0.020 \\
0.015 \\
0.017 \\
0.014 \\
0.017 \\
0.019\end{array}$ & $\begin{array}{l}0.015 \\
0.016 \\
0.015 \\
0.018 \\
0.013 \\
0.014 \\
0.014 \\
0.012 \\
0.017 \\
\end{array}$ & $\begin{array}{l}0.002 \\
0.0 \\
0.0 \\
0.0 \\
0.0 \\
0.0 \\
0.0 \\
0.0 \\
0.0 \\
\end{array}$ & $\begin{array}{l}0.0 \\
0.0 \\
0.0 \\
0.004 \\
0.0 \\
0.0 \\
0.0 \\
0.0 \\
0.0\end{array}$ & $\begin{array}{l}0.0 \\
0.0 \\
0.0 \\
0.0 \\
0.0 \\
0.0 \\
0.0 \\
0.0 \\
0.0\end{array}$ & $\begin{array}{l}1.647 \\
1.622 \\
1.748 \\
1.719 \\
1.738 \\
1.735 \\
1.753 \\
1.686 \\
1.678 \\
\end{array}$ & $\begin{array}{l}2.322 \\
2.332 \\
2.225 \\
2.242 \\
2.229 \\
2.224 \\
2.219 \\
2.283 \\
2.285\end{array}$ & $\begin{array}{l}\text { Outermost rim } \\
\text { Core } \\
\text { Rim } \\
\text { Core } \\
\text { Rim }\end{array}$ \\
\hline
\end{tabular}


TABLE 8 - Continued

\begin{tabular}{|c|c|c|c|c|c|c|c|c|c|c|c|c|}
\hline $\begin{array}{l}\text { Bochum } \\
\text { No. }\end{array}$ & Point & $\mathrm{K}$ & $\mathrm{Na}$ & $\mathrm{Ca}$ & $\mathrm{Mg}$ & $\mathrm{Fe}^{2+}$ & Mn & $\mathrm{Ti}$ & $\mathrm{Cr}$ & $\mathrm{Al}$ & $\mathrm{Si}$ & Remarks \\
\hline \multirow[t]{11}{*}{1200} & 26 & 0.001 & 0.204 & 0.816 & 0.016 & 0.012 & 0.0 & 0.005 & 0.0 & 1.686 & 2.258 & Core \\
\hline & 27 & 0.001 & 0.153 & 0.873 & 0.014 & 0.011 & 0.0 & 0.0 & 0.0 & 1.768 & 2.186 & Rim \\
\hline & 30 & 0.001 & 0.193 & 0.835 & 0.014 & 0.012 & 0.002 & 0.0 & 0.0 & 1.720 & 2.230 & Core \\
\hline & 31 & 0.0 & 0.189 & 0.832 & 0.015 & 0.013 & 0.0 & 0.0 & 0.0 & 1.734 & 2.222 & \\
\hline & 33 & 0.0 & 0.196 & 0.831 & 0.016 & 0.015 & 0.0 & 0.0 & 0.0 & 1.700 & 2.245 & \\
\hline & 34 & 0.0 & 0.177 & 0.834 & 0.023 & 0.013 & 0.002 & 0.013 & 0.002 & 1.724 & 2.212 & \\
\hline & 35 & 0.0 & 0.187 & 0.835 & 0.016 & 0.011 & 0.0 & 0.0 & 0.0 & 1.715 & 2.236 & \\
\hline & 36 & 0.0 & 0.187 & 0.834 & 0.015 & 0.013 & 0.0 & 0.0 & 0.0 & 1.719 & 2.233 & \\
\hline & 37 & 0.0 & 0.210 & 0.823 & 0.017 & 0.013 & 0.0 & 0.0 & 0.0 & 1.700 & 2.246 & Rim \\
\hline & 38 & 0.001 & 0.271 & 0.785 & 0.017 & 0.016 & 0.0 & 0.0 & 0.0 & 1.641 & 2.292 & Rim, pheno \\
\hline & 39 & 0.001 & 0.183 & 0.843 & 0.015 & 0.016 & 0.0 & 0.0 & 0.0 & 1.733 & 2.217 & Pheno \\
\hline 1280 & 63 & 0.002 & 0.304 & 0.695 & 0.023 & 0.030 & 0.0 & 0.004 & 0.0 & 1.573 & 2.366 & Groundmass cryst. \\
\hline \multirow[t]{4}{*}{1370} & 42 & 0.001 & 0.272 & 0.734 & 0.015 & 0.019 & 0.0 & 0.0 & 0.0 & 1.619 & 2.333 & Pheno \\
\hline & 44 & 0.002 & 0.276 & 0.724 & 0.018 & 0.018 & 0.0 & 0.002 & 0.0 & 1.610 & 2.341 & Pheno \\
\hline & 45 & 0.001 & 0.221 & 0.804 & 0.021 & 0.013 & 0.0 & 0.0 & 0.0 & 1.674 & 2.270 & Core \\
\hline & 46 & 0.0 & 0.151 & 0.877 & 0.016 & 0.015 & 0.0 & 0.0 & 0.0 & 1.762 & 2.187 & Rim \\
\hline
\end{tabular}

TABLE 9

Modal Analyses (\%) of Selected Samples From Hole 396B

\begin{tabular}{cccccccr}
\hline $\begin{array}{l}\text { Bochum } \\
\begin{array}{c}\text { Sample } \\
\text { No. }\end{array}\end{array}$ & Plag. & Ol. & Glasses & Voids & Plag/ol. & Total (\%) & $\begin{array}{r}\text { Pounts } \\
\text { Counted }\end{array}$ \\
\hline 600 & 15.6 & 1.3 & 83.0 & 0.1 & 12.0 & 100 & 2853 \\
980 & 15.5 & 2.4 & 82.1 & $<0.1$ & 6.5 & 100.1 & 3615 \\
1110 & 15.6 & 0.9 & 83.4 & - & 17.3 & 99.9 & 1957 \\
1140 & 17.7 & 2.0 & 80.3 & - & 8.9 & 100 & 1955 \\
1180 & 21.9 & 2.3 & 75.8 & - & 9.5 & 100 & 3687 \\
$860 / 870$ & 17.3 & 2.9 & 79.5 & 0.3 & 6.0 & 100 & 2059 \\
940 & 16.1 & 3.4 & 80.4 & $<0.1$ & 4.7 & 100 & 1920 \\
1000 & 15.7 & 1.6 & 81.2 & 1.6 & 9.8 & 100.1 & 2301 \\
1020 & 23.7 & 6.2 & 68.3 & 1.9 & 3.8 & 99.9 & 2273 \\
1030 & 18.2 & 2.8 & 79.0 & $<0.01$ & 6.5 & 100.01 & 2369 \\
1060 & 14.9 & 2.0 & 82.2 & 1.0 & 7.5 & 100.1 & 2152 \\
1090 & 18.7 & 4.4 & 77.0 & $<0.1$ & 4.3 & 100.2 & 10,948 \\
1360 & 14.5 & 1.7 & 83.8 & $<0.1$ & 8.5 & 100.1 & 1989 \\
1370 & 8.1 & 2.2 & 89.4 & $<1.0$ & 3.7 & 100.7 & 2374 \\
\hline
\end{tabular}




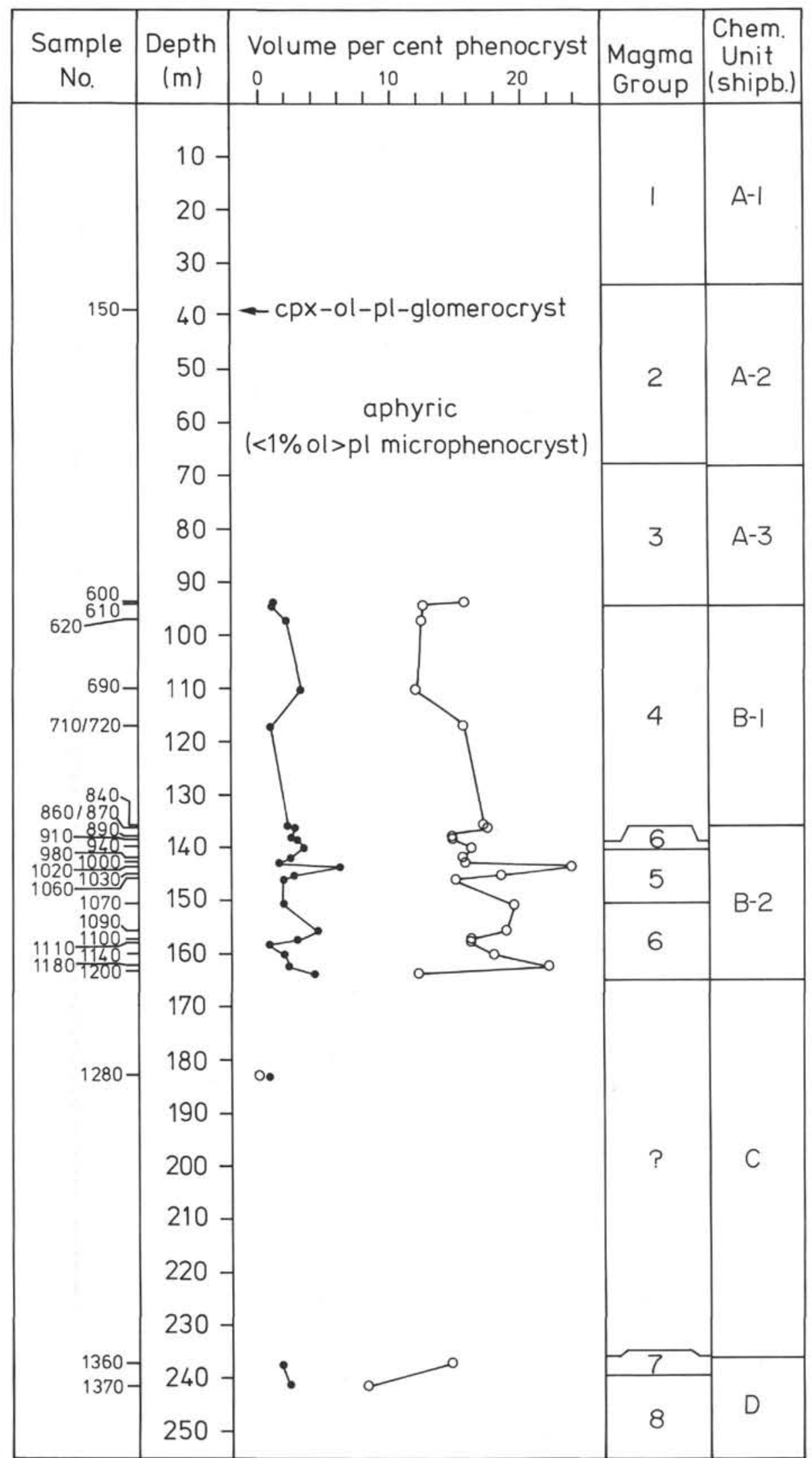

Figure 2. Volume per cent of olivine ( $\bullet$ ) and plagioclase $(\circ)$ phenocrysts plotted with depth, for modally analyzed samples (see Table 9). 


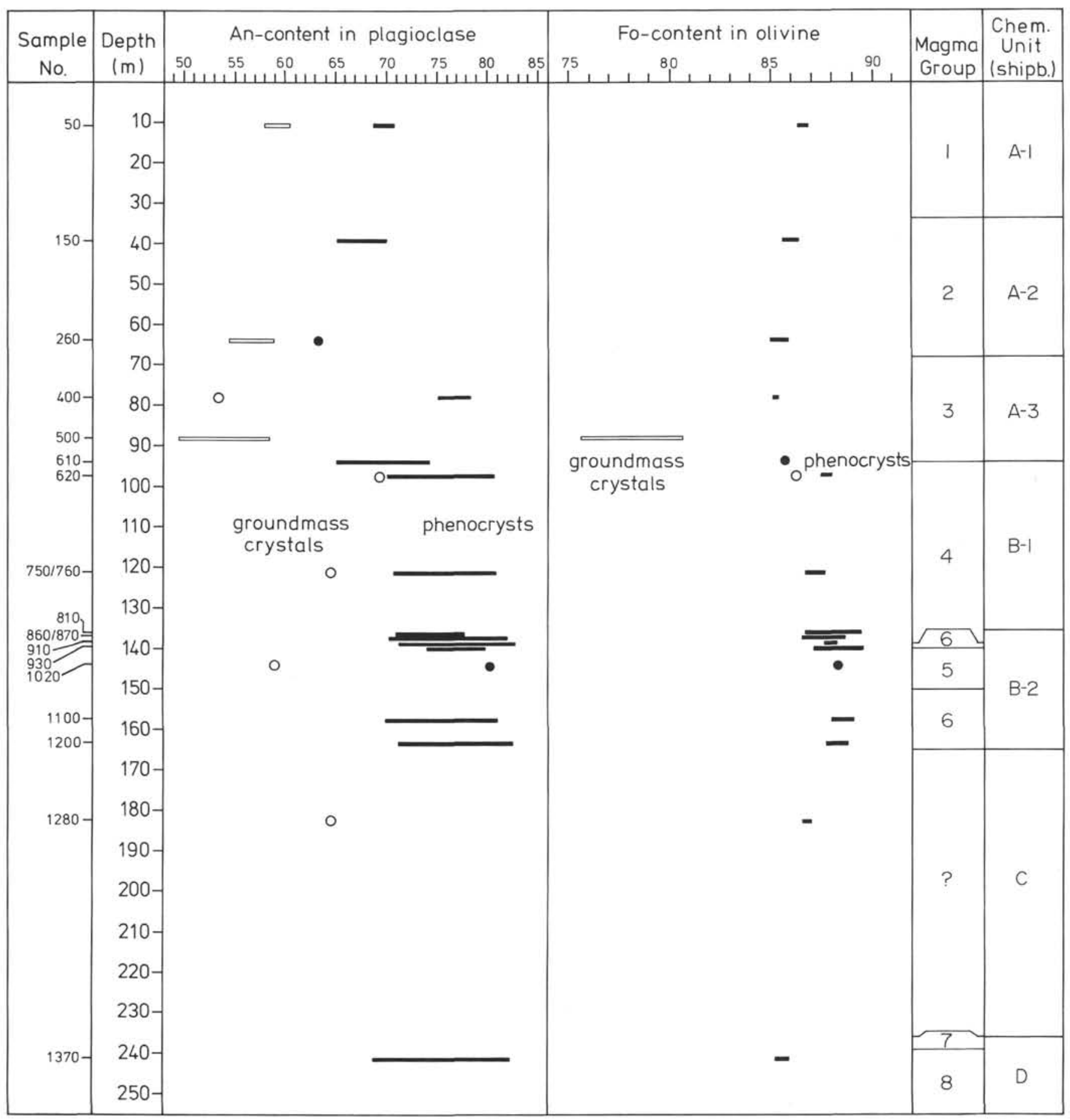

Figure 3. Ranges of plagioclase and olivine compositions for phenocrysts and groundmass crystals plotted with depth; data from electron microprobe analyses (see Tables 6 and 8). 


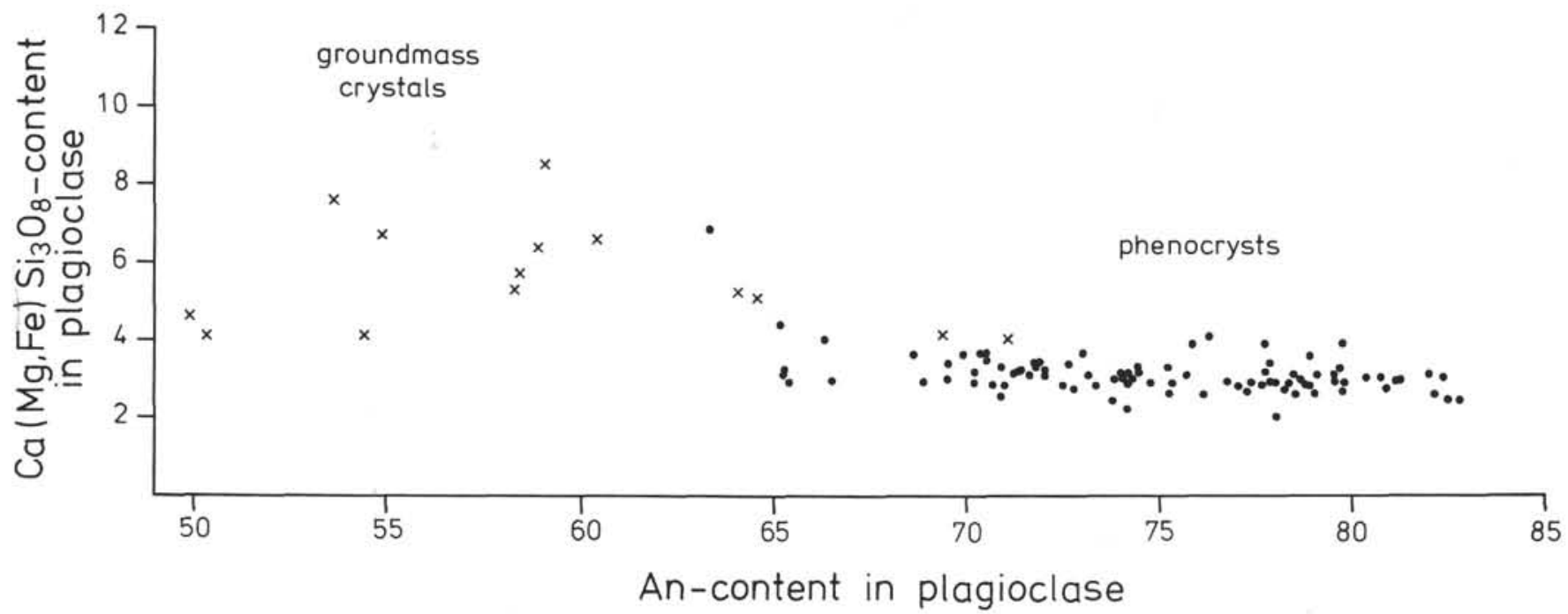

Figure 4. Molecular $\mathrm{Ca}(\mathrm{Mg}, \mathrm{Fe}) \mathrm{Si}_{3} \mathrm{O}_{8}$ content in groundmass and phenocryst plagioclase plotted against anorthite; from electron microprobe data in Table 8.

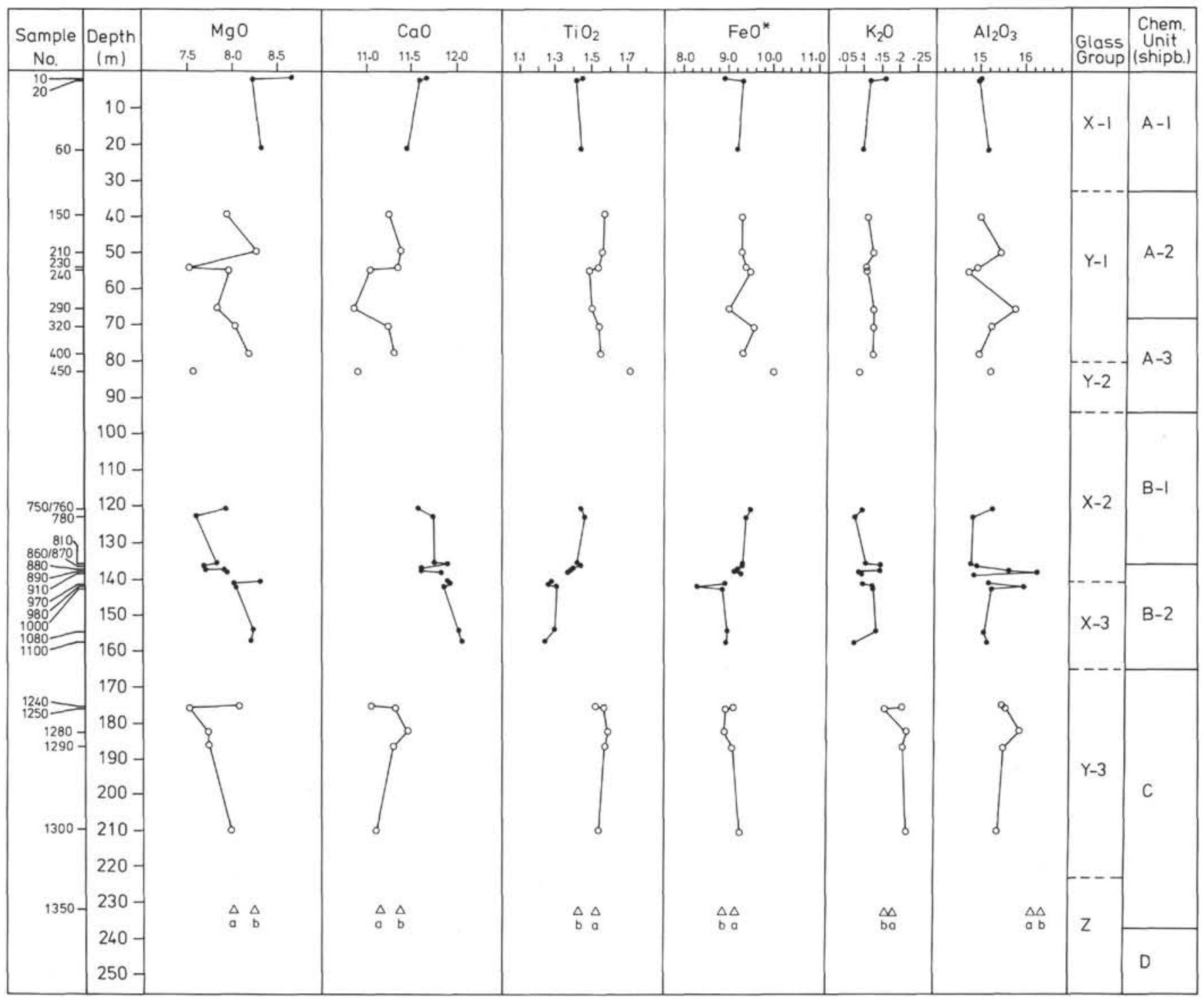

Figure 5. Plots of oxide contents for $\mathrm{MgO}, \mathrm{CaO}, \mathrm{TiO}_{2}, \mathrm{FeO}$ (total $\mathrm{Fe}$-oxide), $\mathrm{K}_{2} \mathrm{O}$, and $\mathrm{Al}_{2} \mathrm{O}_{3}$ versus sub-basement depth for glass compositions. Liquid types are indicated. 

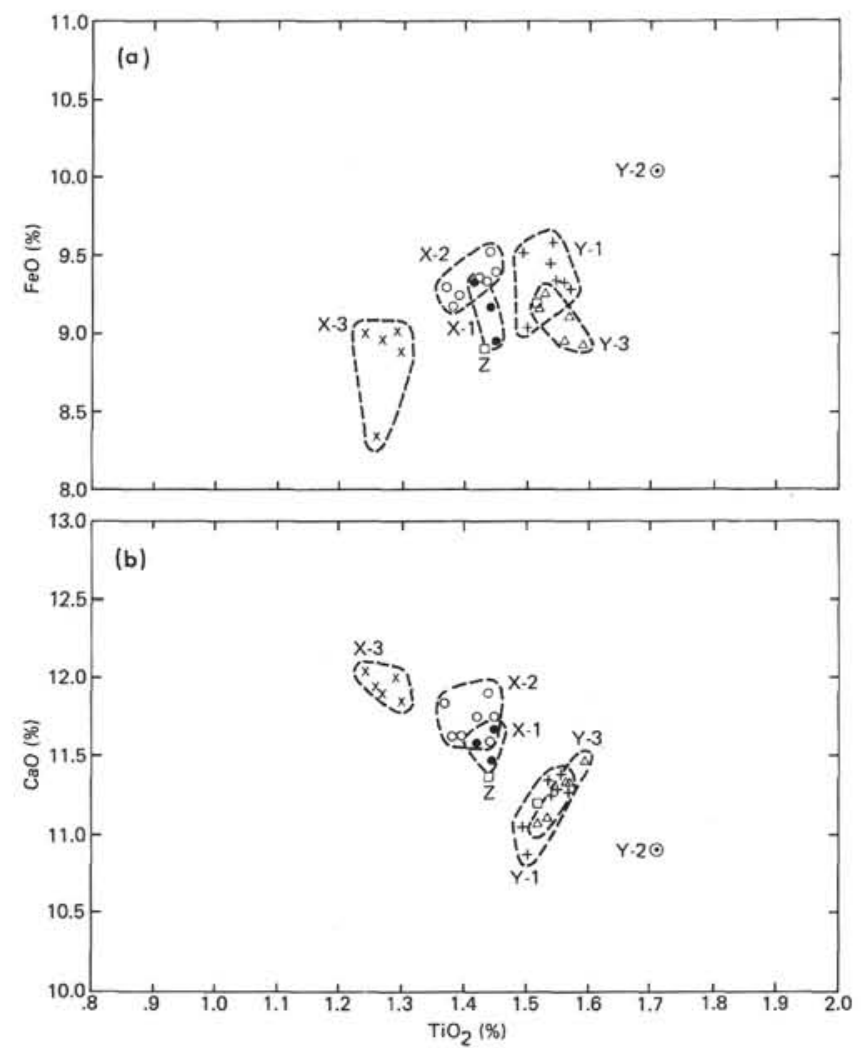

Figure 6. Plots of (a) $\mathrm{FeO}$ versus $\mathrm{TiO}_{2}$, and (b) $\mathrm{CaO}$ versus $\mathrm{TiO}_{2}$ for glass compositions; compositional-stratigraphic groups outlined. 

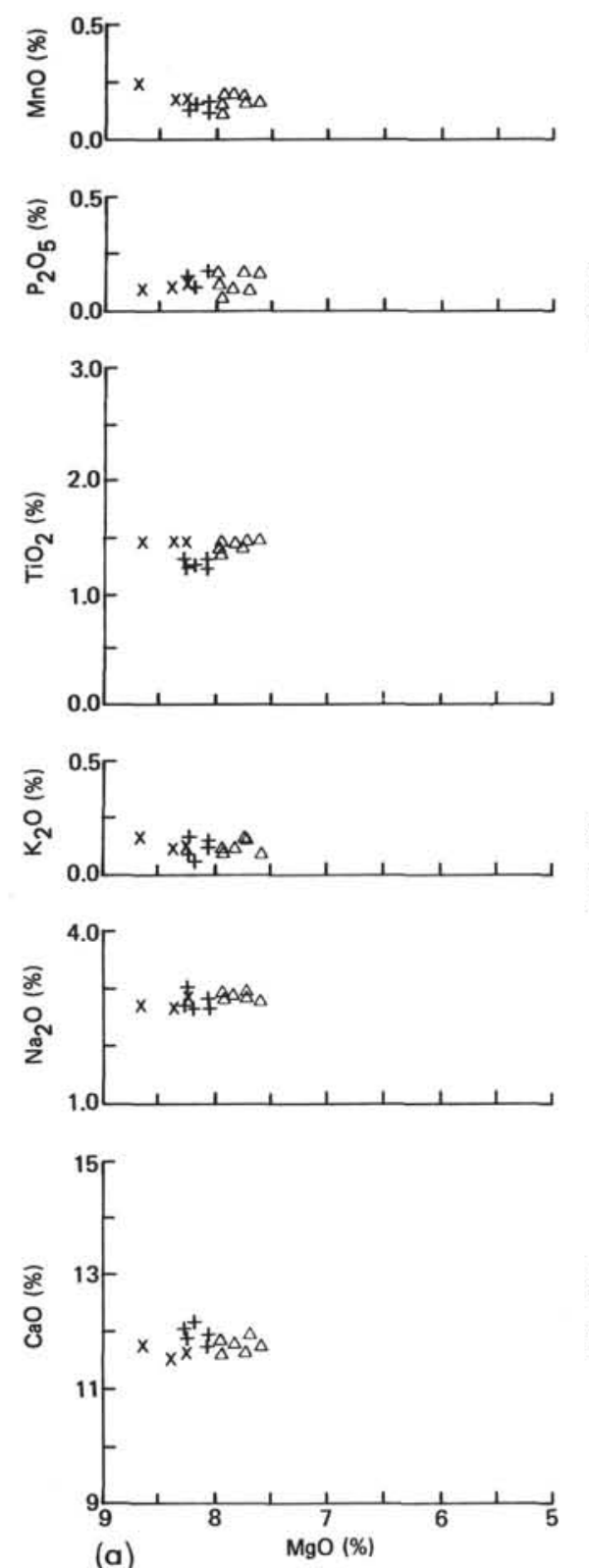

Figure 7
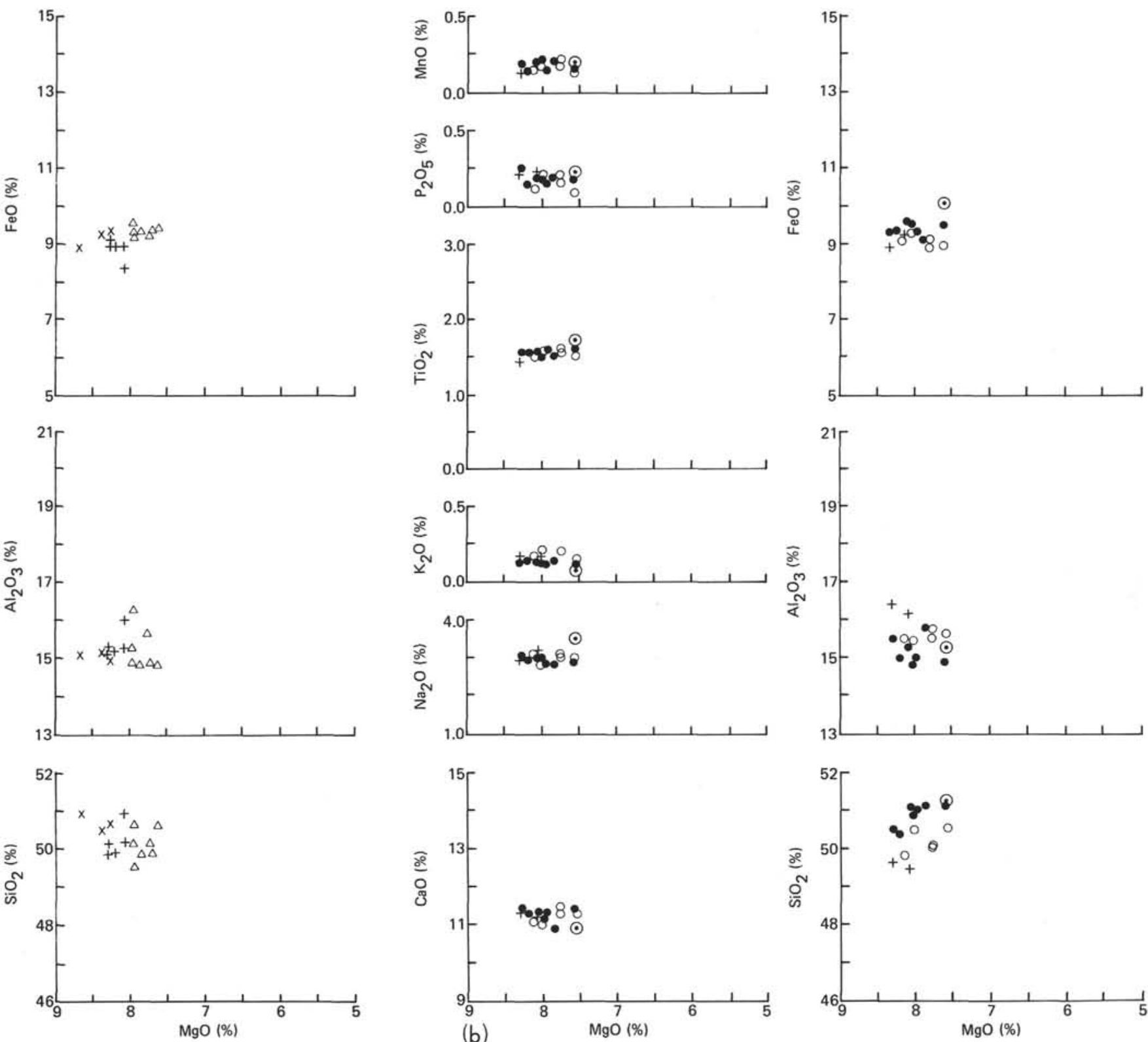

(b)

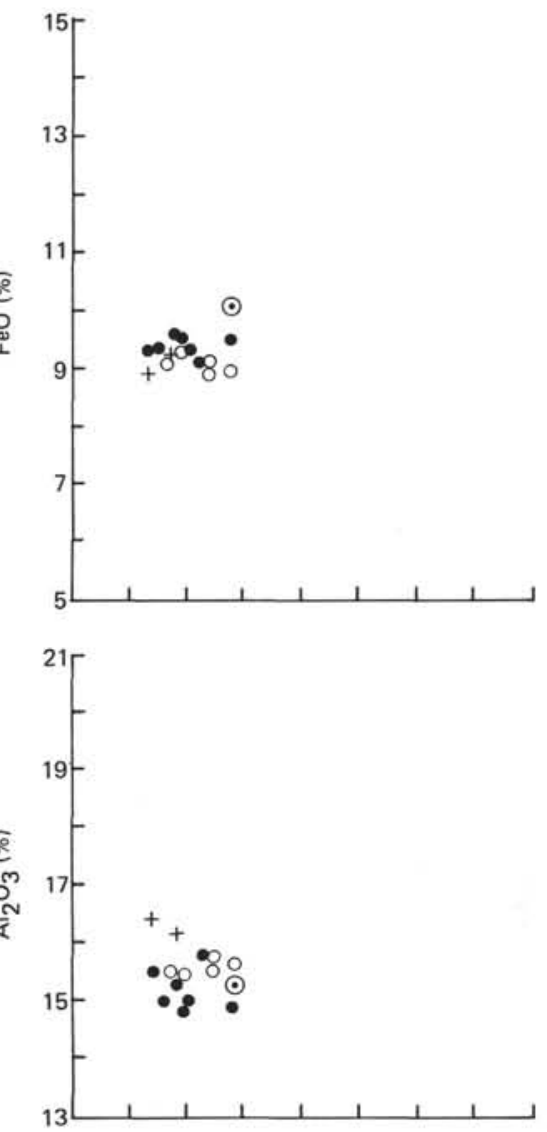



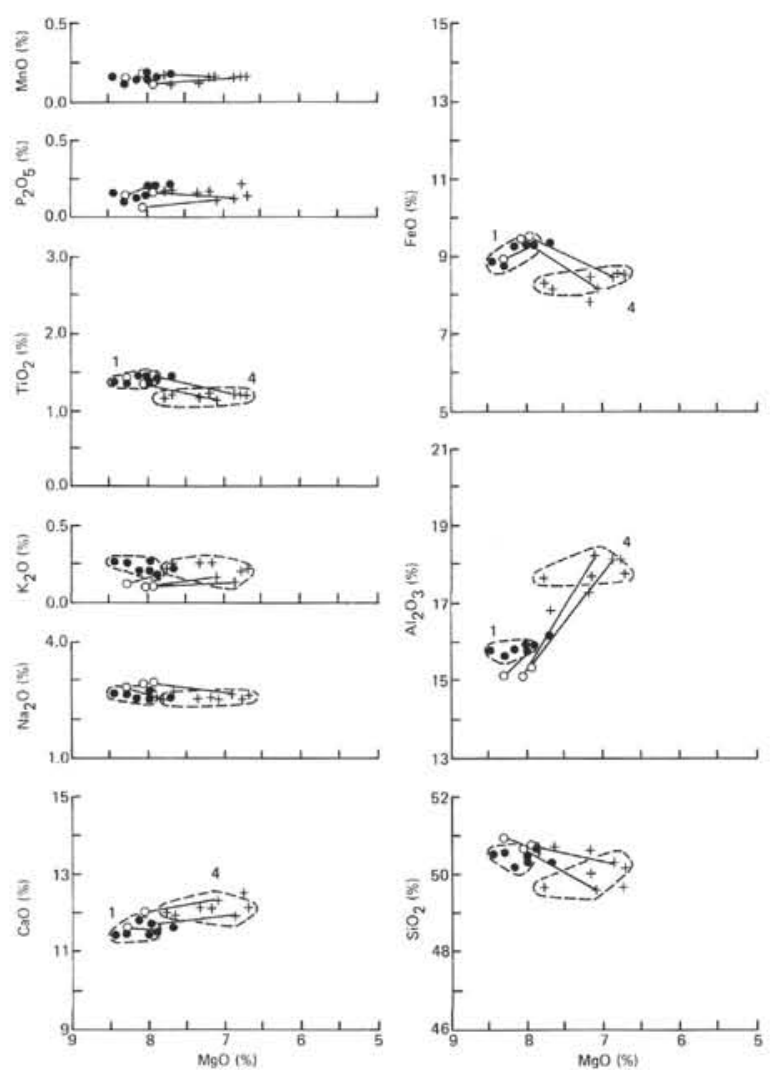
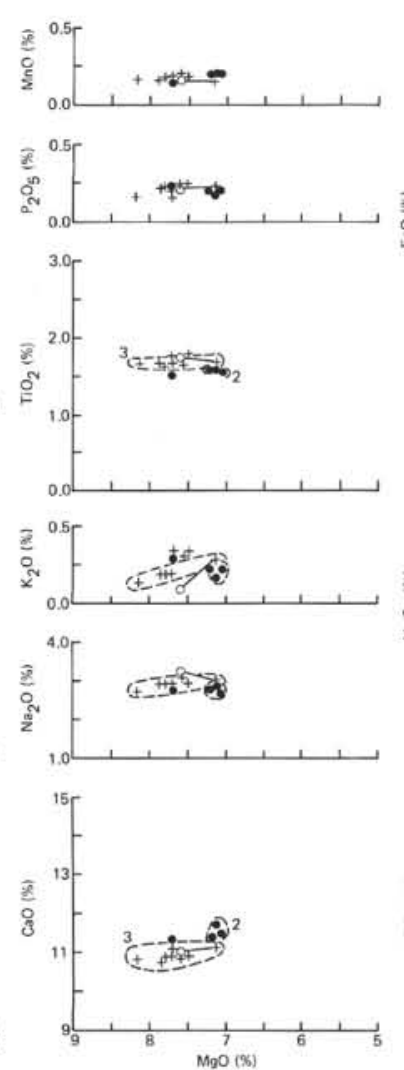
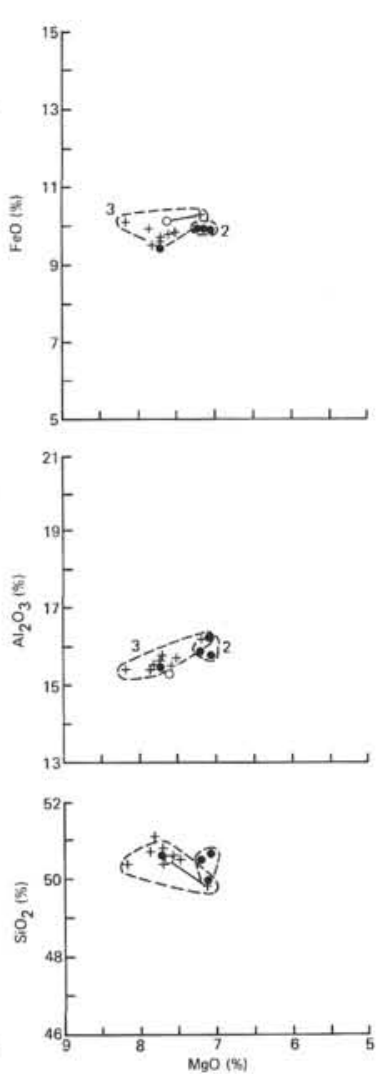
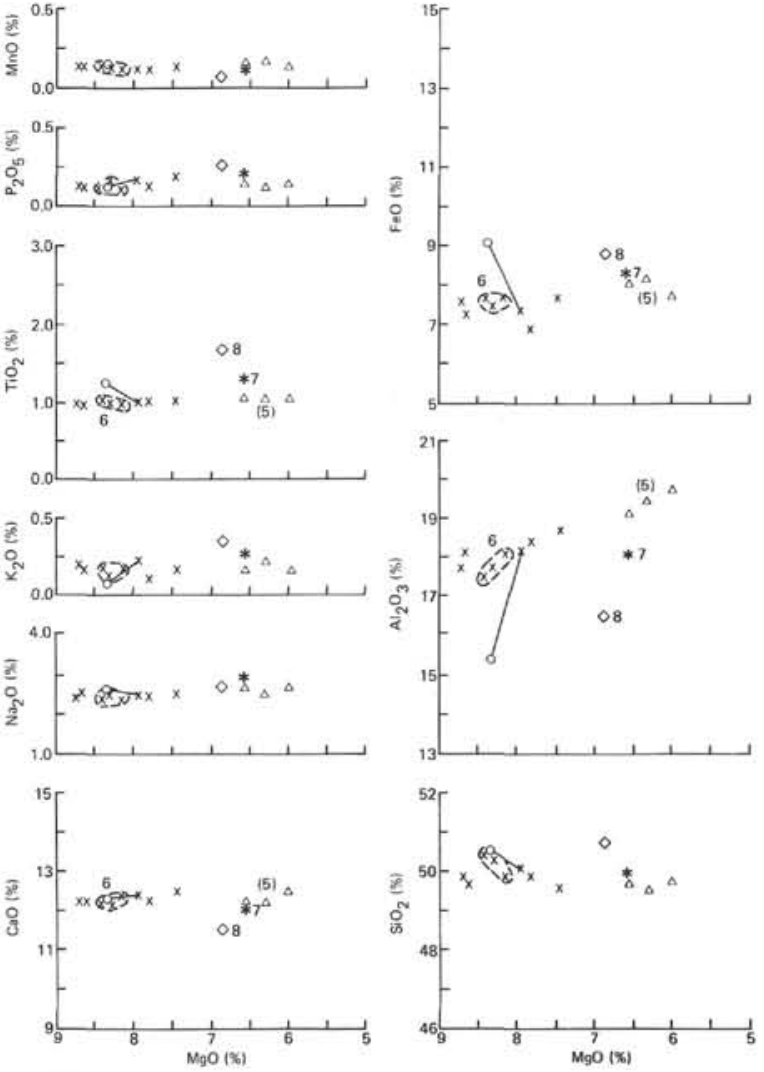

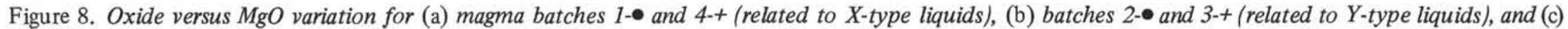
batches 5- $\triangle$ and $6-x$ (related to X-type liquids), and 7-* and 8- $\diamond$ (probably Y-types). All analyses are corrected for carbonate (see text) and normalized to a $\mathrm{H}_{2} \mathrm{O}^{+}$-free basis. Those with less than $1.25 \% \mathrm{H}_{2} \mathrm{O}^{+}$("fresh" samples) are outlined in terms of respective groupings. Representative tie-lines have been drawn between whole rock and associated glass cooling rind compositions. 


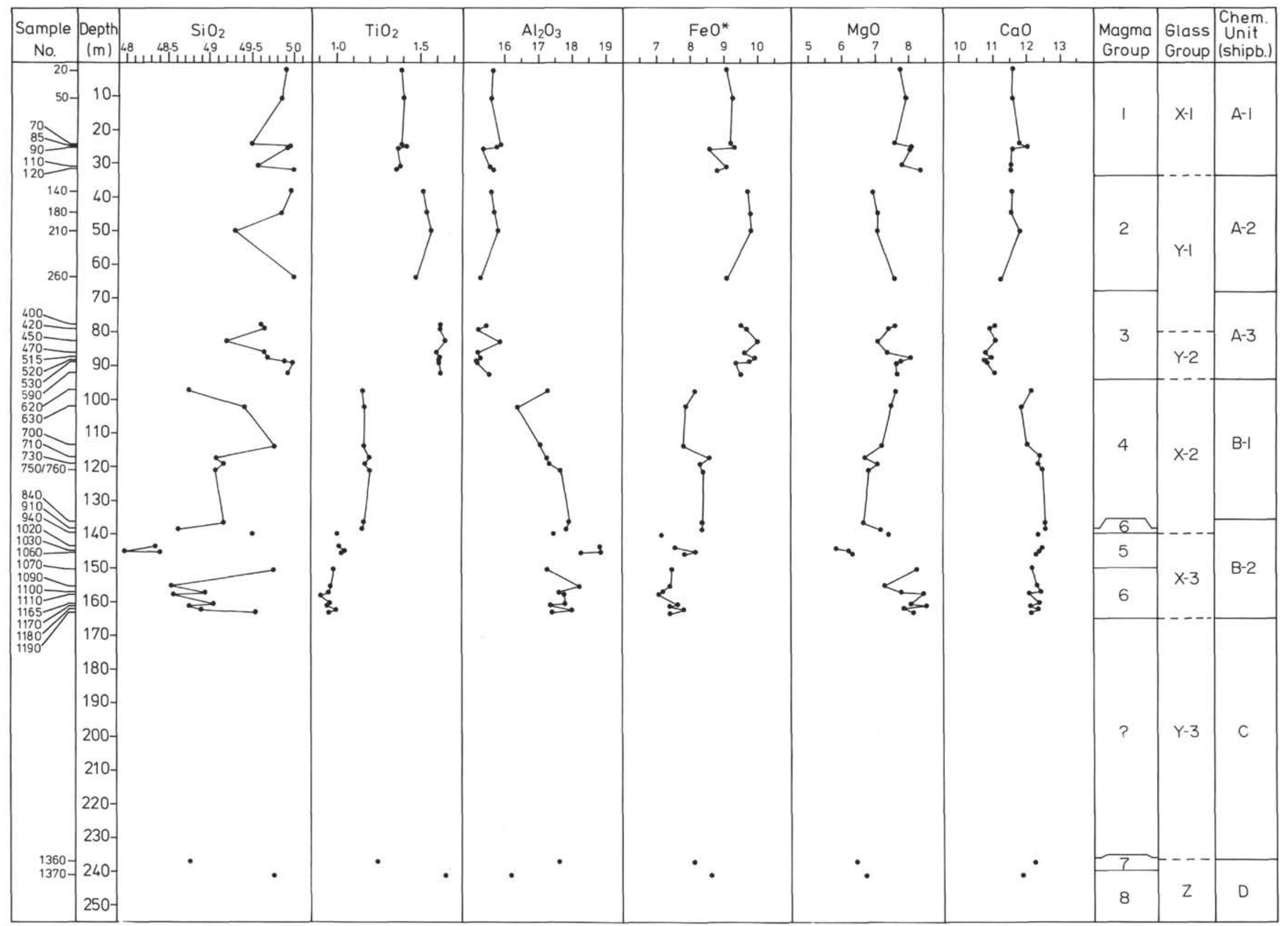

Figure 9a. Plots of major oxides versus sub-basement depth for whole-rock compositions. Magma groupings are indicated for their approximate stratigraphic occurrence. Plots of $\mathrm{SiO}_{2}, \mathrm{TiO}_{2}, \mathrm{Al}_{2} \mathrm{O}_{3}, \mathrm{FeO}$ (total iron), $\mathrm{MgO}$, and $\mathrm{CaO}$ versus sub-basement depth. 


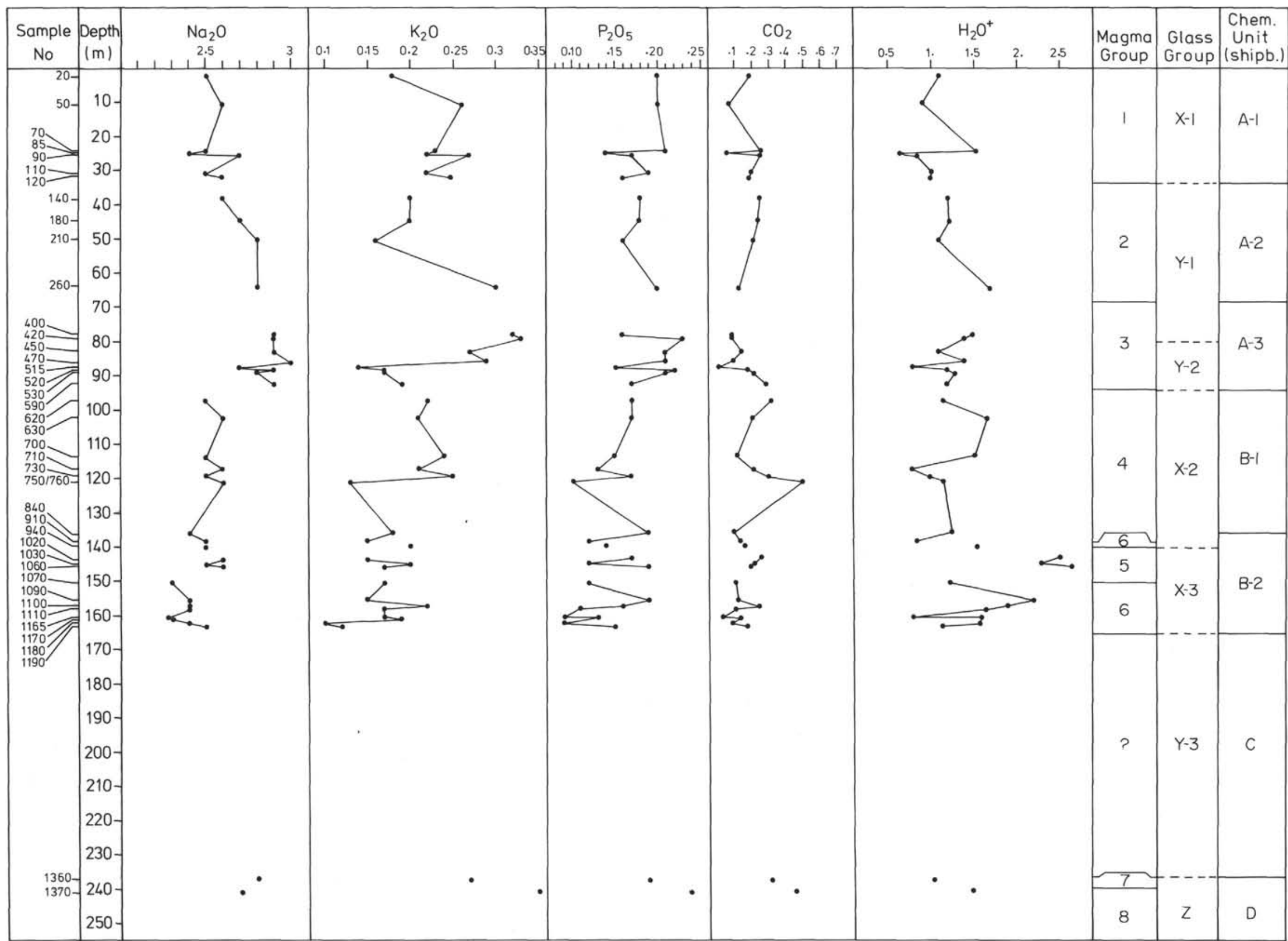

Figure $9 \mathrm{~b}$. Plots of major oxides versus sub-basement depth for whole-rock compositions. Magma groupings are indicated for their approximate stratigraphic occurrences. Plots of $\mathrm{Na}_{2} \mathrm{O}, \mathrm{K}_{2} \mathrm{O}, \mathrm{P}_{2} \mathrm{O}_{5}, \mathrm{CO}_{2}$, and $\mathrm{H}_{2} \mathrm{O}+$ versus sub-basement depth. 


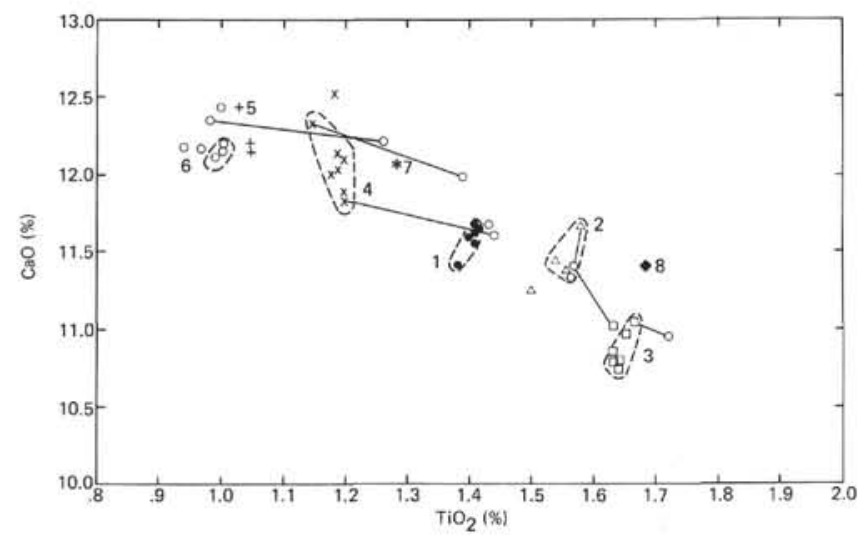

Figure 10. $\mathrm{CaO}$ versus $\mathrm{TiO}_{2}$ for whole rock compositions, carbonate-corrected and normalized to a $\mathrm{H}_{2} \mathrm{O}^{+}$-free basis. Tie-lines drawn to associated glass cooling rind compositions; magma batches $1=\bullet, 2=\Delta, 3=\square, 4=\mathrm{x}$, $5=+, 6=0,7=*$, and $8=\$$, outlined for samples with $1.25 \% \mathrm{H}_{2} \mathrm{O}^{+}$.
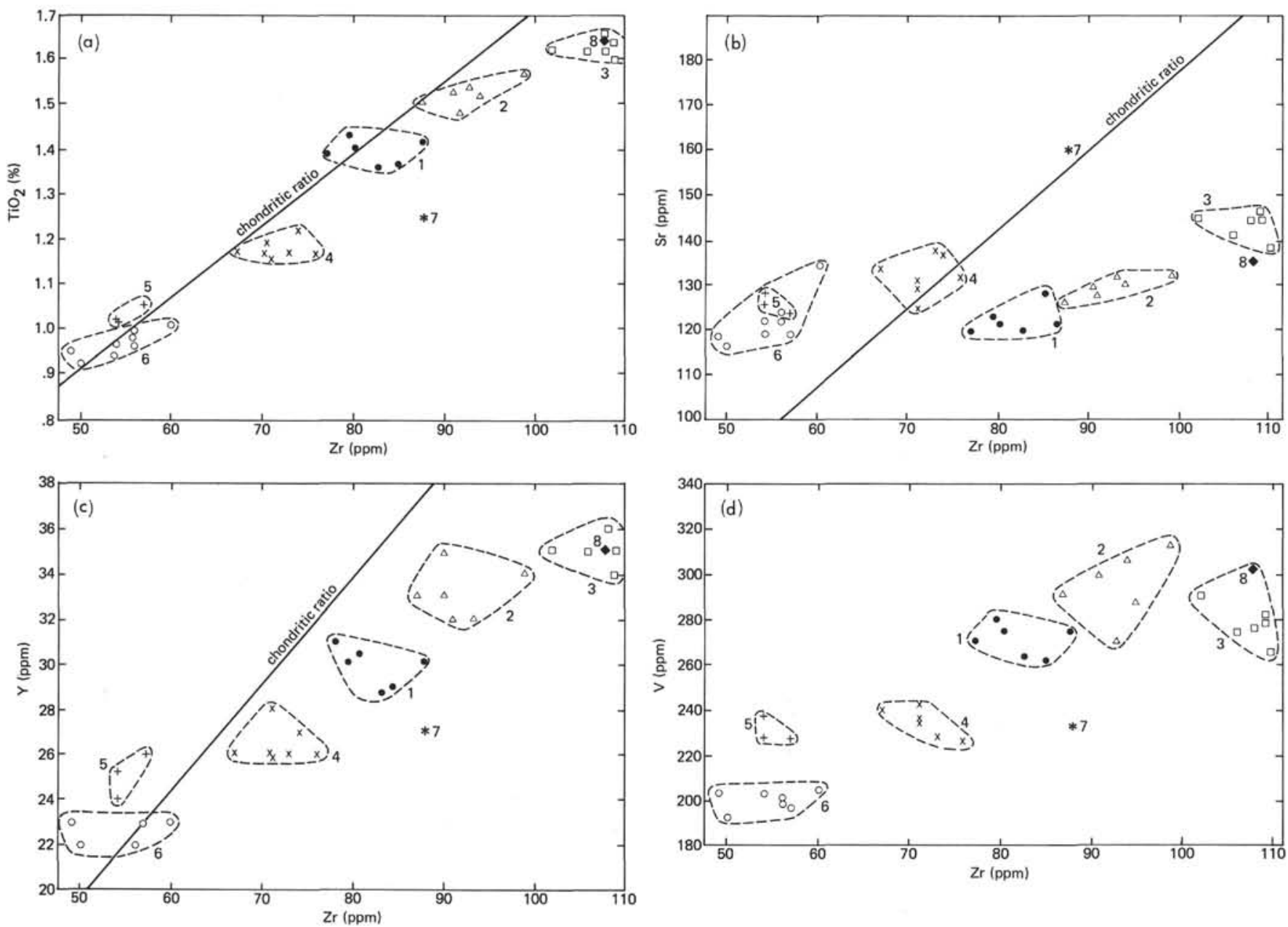

Figure 11. Plots of large ion lithophile elements versus $\mathrm{Zr}$ : (a) $\mathrm{TiO}_{2}$, (b) $\mathrm{Y}$, (c) $\mathrm{Sr}$, (d) $\mathrm{V}$; magma batches are outlined (chondritic Ti/Zr av. $\approx 103$, Leg 46 range: 107 to 92 [X-3 to $Y$-2]; chondritic $Y / Z r$ av. $\approx 0.43$, Leg 46 range: 0.46 to $0.32[X-3$

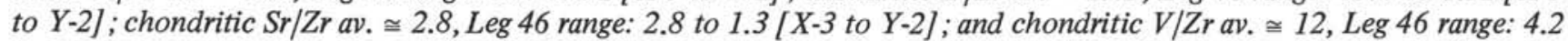
to $2.6[X-3$ to $Y-2])$. 


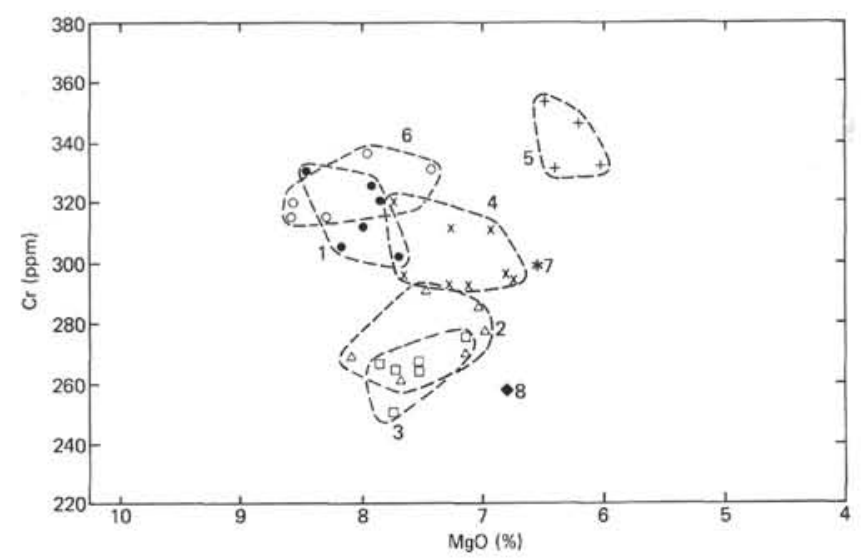

Figure 12. Plots of $\mathrm{Cr}$ versus $\mathrm{MgO}$ with postulated magma batches outlined. Magma batch $1=\bullet, 2=\triangle, 3=\square, 4=\mathrm{x}$, $5=+, 6=0,7=*$, and $8=$.
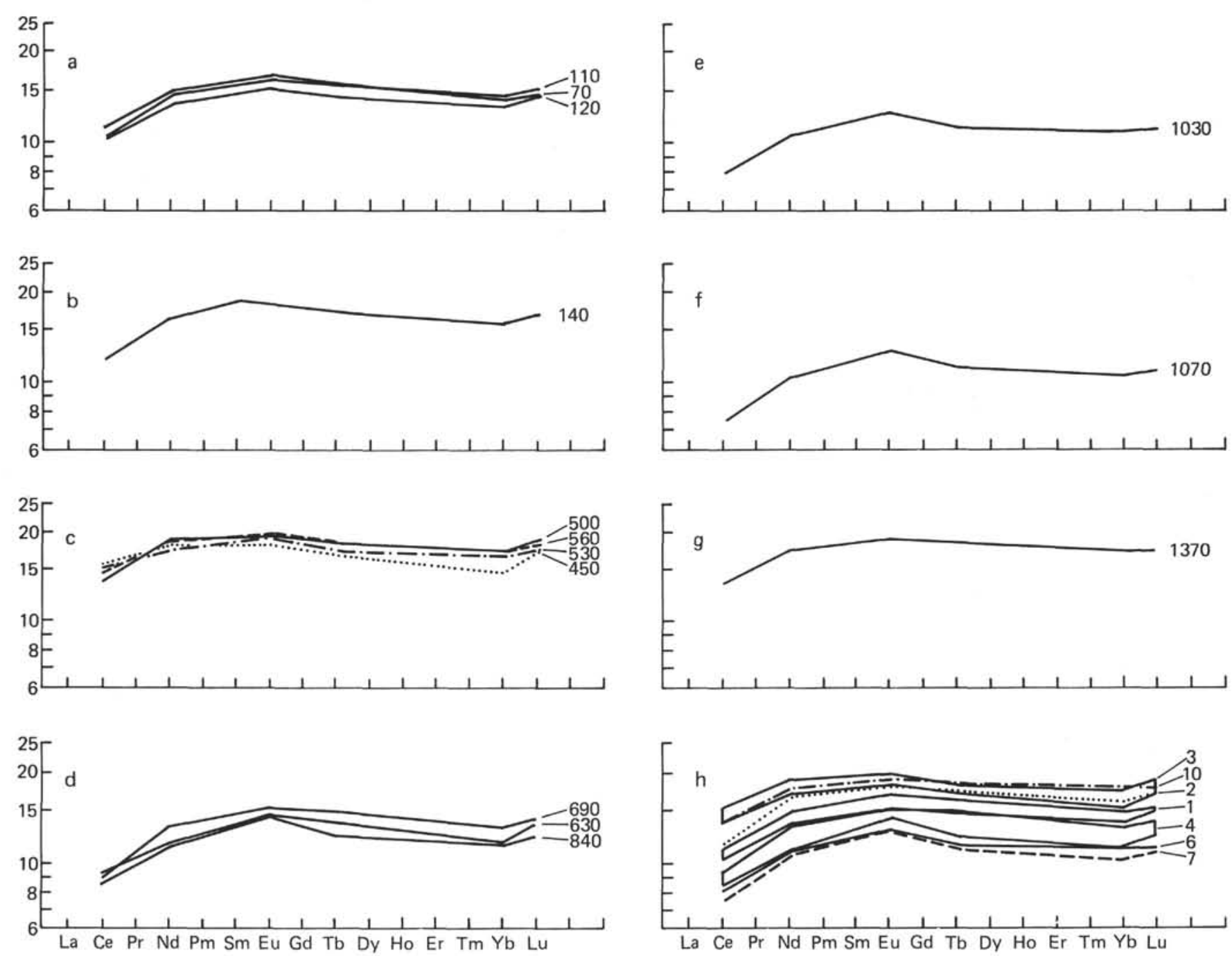

Figure 13. Plots of chondrite-normalized rare earth element abundances, with increasing rare earth atomic number, according to magma batches: (a) 1, (b) 2, (c) 3, (d) 4, (e) 5, (f) 6, and (g) 8, and in (h) a summary for the respective magma batch ranges. 

PLATE 1

Figure 1 Olivine-Plagioclase-Clinopyroxene glomerocryst. Bochum Sample 150; DSDP Sample 396B-8-2, 3-7 $\mathrm{cm} . \mathrm{O}=$ Olivine, $\mathrm{C}=$ Clinopyroxene .

Figure 2 Plagioclases. Bochum Sample 610; DSDP Sample 396B-15-5, 108-111 cm.

Figure 3 Plagioclases. Bochum Sample 1110; DSDP Sample 396B-22-2, 8-12 cm.

Figure 4 Plagioclases. Bochum Sample 700; DSDP Sample 396B-16-5, 34-36 cm. 
PLATE 1

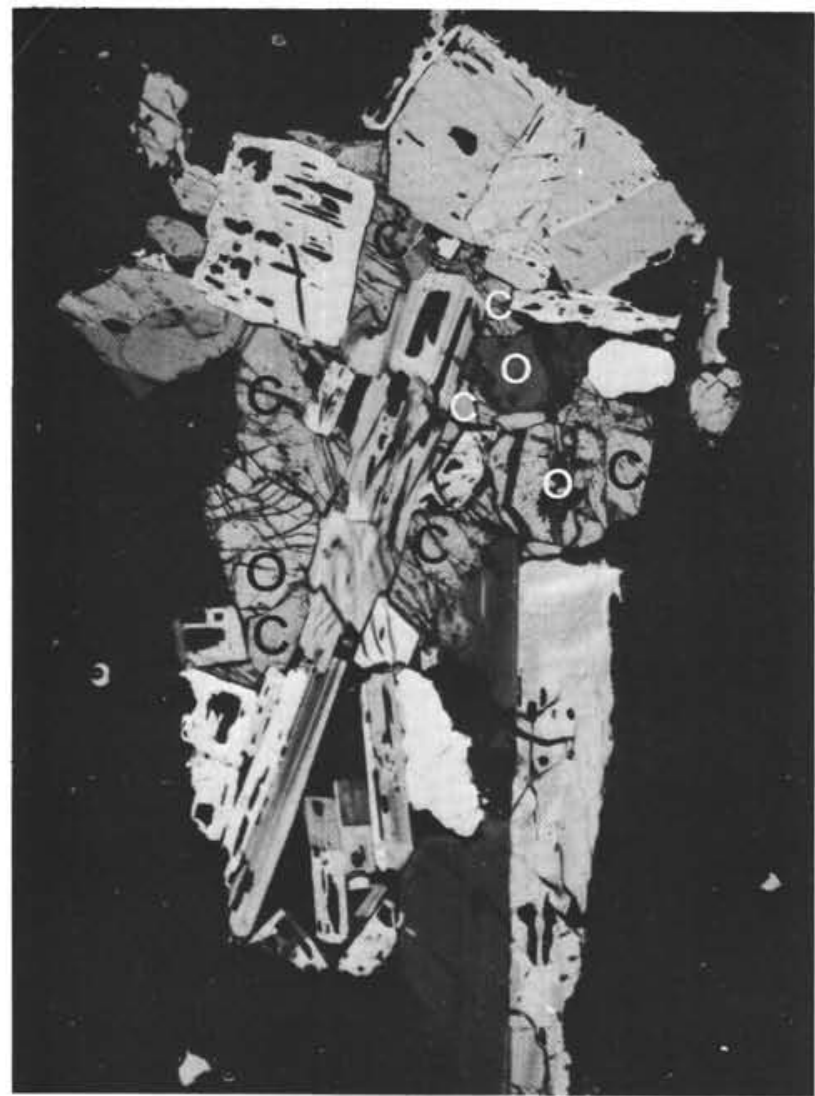

1

$\overline{0.5 \mathrm{~mm}}$

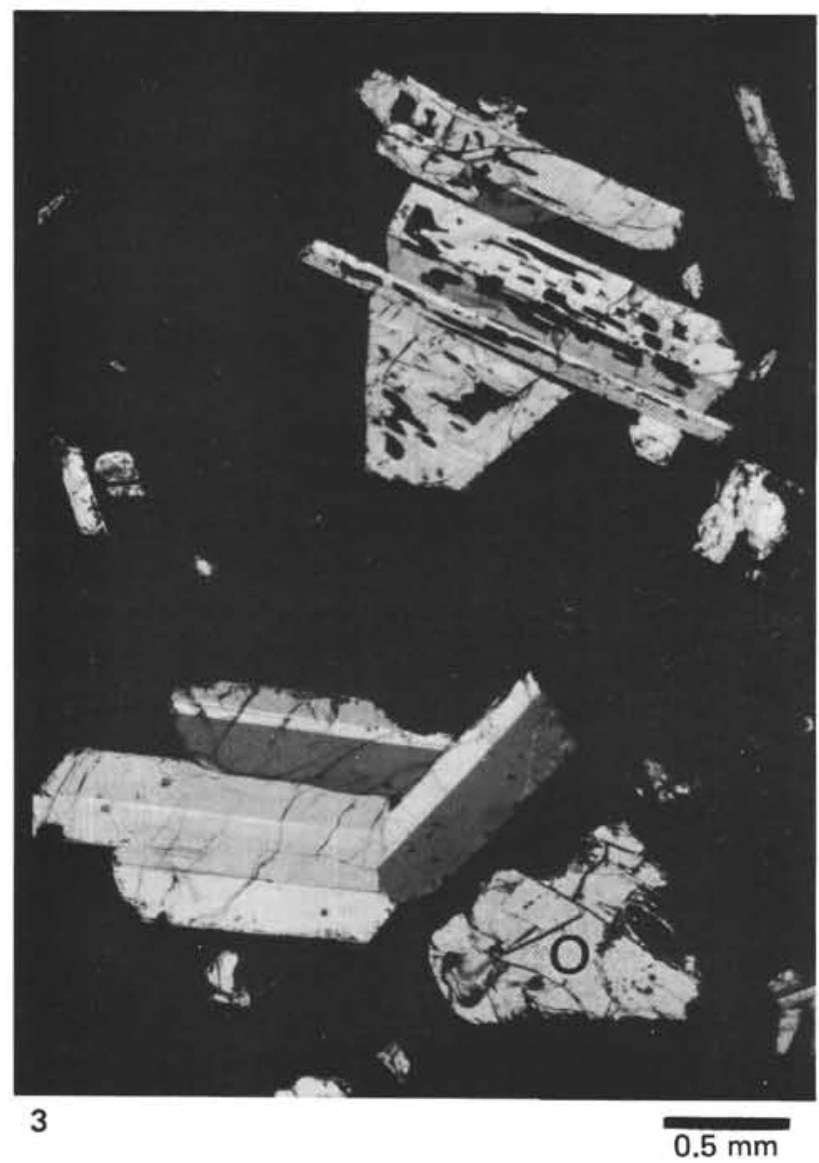

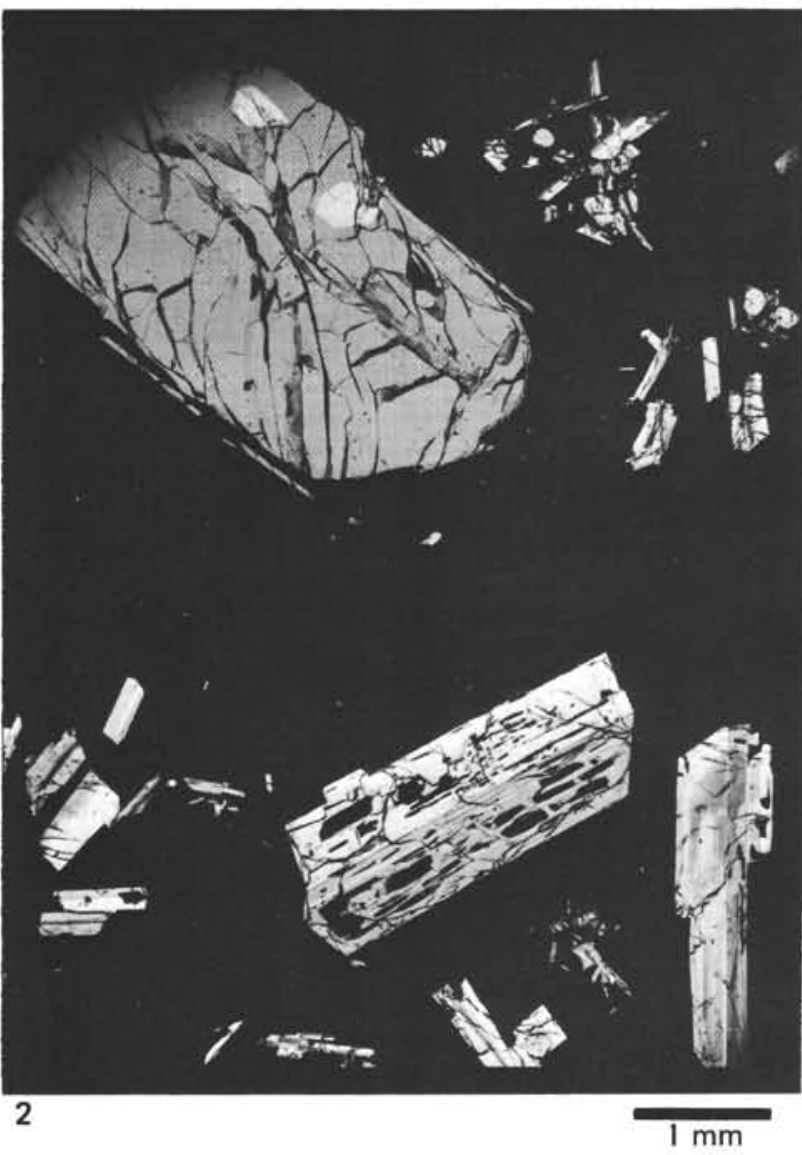

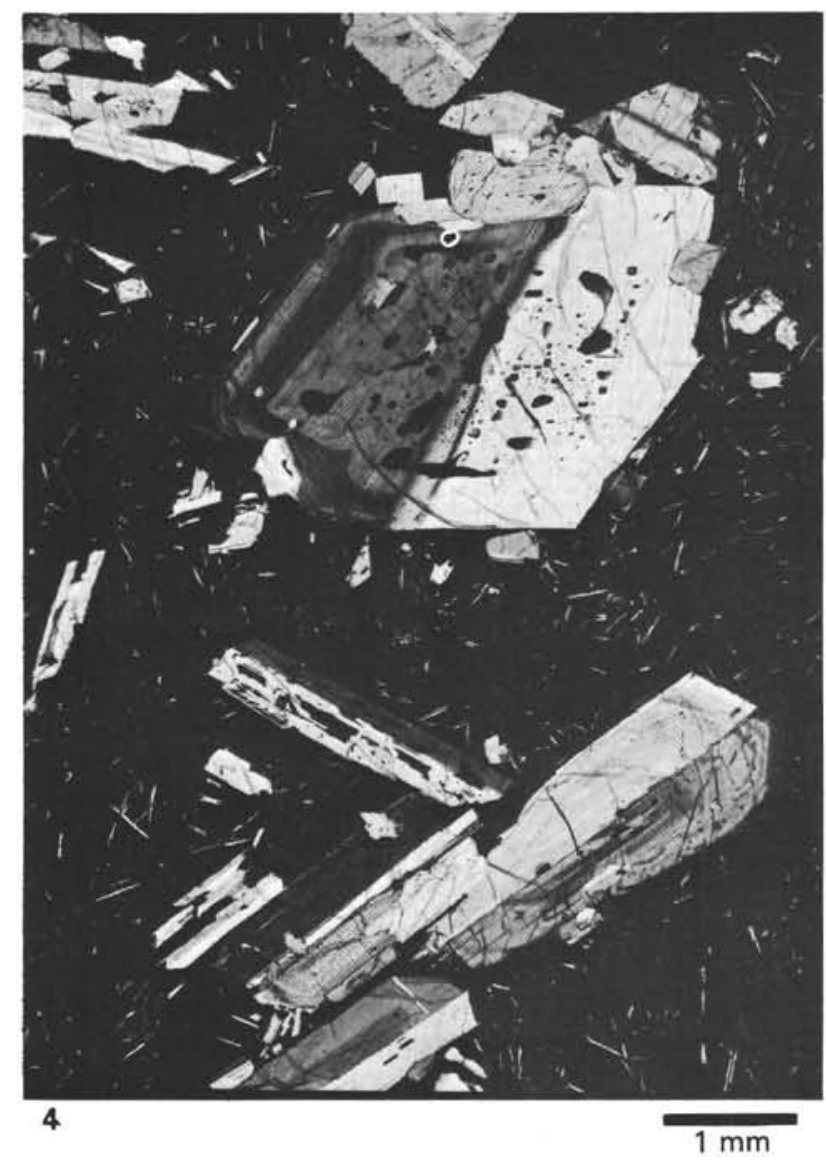




\section{PLATE 2 \\ Plagioclases}

Figure 1 Bochum Sample 1170; DSDP Sample 396B-22-3, $49-56 \mathrm{~cm}$.

Figure 2 Bochum Sample 860/870; DSDP Sample 396B-20-1, $70-80 \mathrm{~cm}$.

Figure 3 Bochum Sample 600; DSDP Sample 396B-15-5, $102-105 \mathrm{~cm}$.

Figure 4 Bochum Sample 910; DSDP Sample 396B-20-2, $58-67 \mathrm{~cm}$. 
PLATE 2
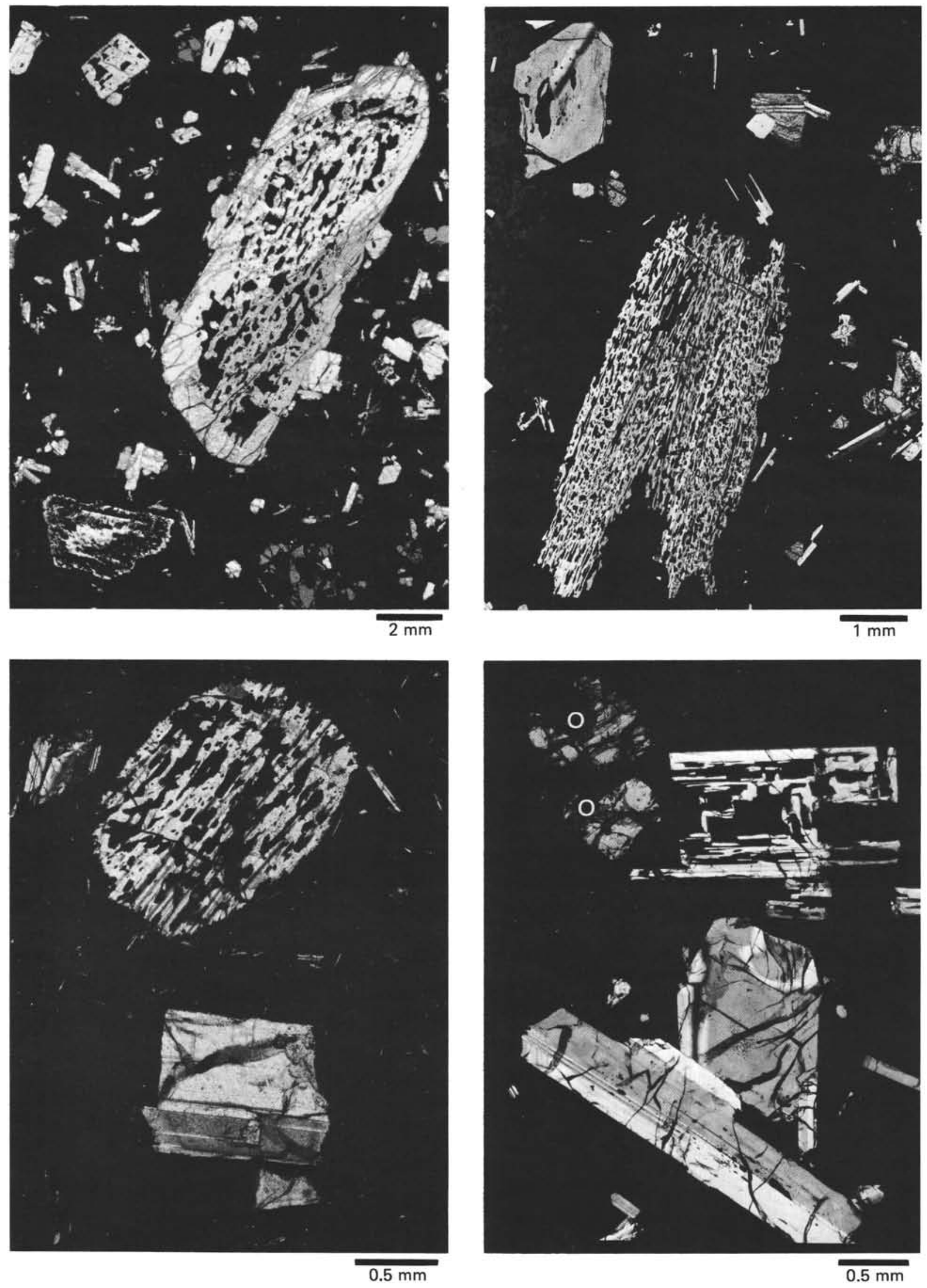


\section{PLATE 3}

Plagioclases

Figure 1 Bochum Sample 840; DSDP Sample 396B-20-1, $35-42 \mathrm{~cm}$.

Figure 2 Bochum Sample 710/720; DSDP Sample 396B-17-1, $4-7 \mathrm{~cm}$.

Figure 3 Bochum Sample 1100; DSDP Sample 396B-22-1, $125-134 \mathrm{~cm}$.

Figure 4 Bochum Sample 1100; DSDP Sample 396B-22-1, $125-134 \mathrm{~cm}$. 
PLATE 3
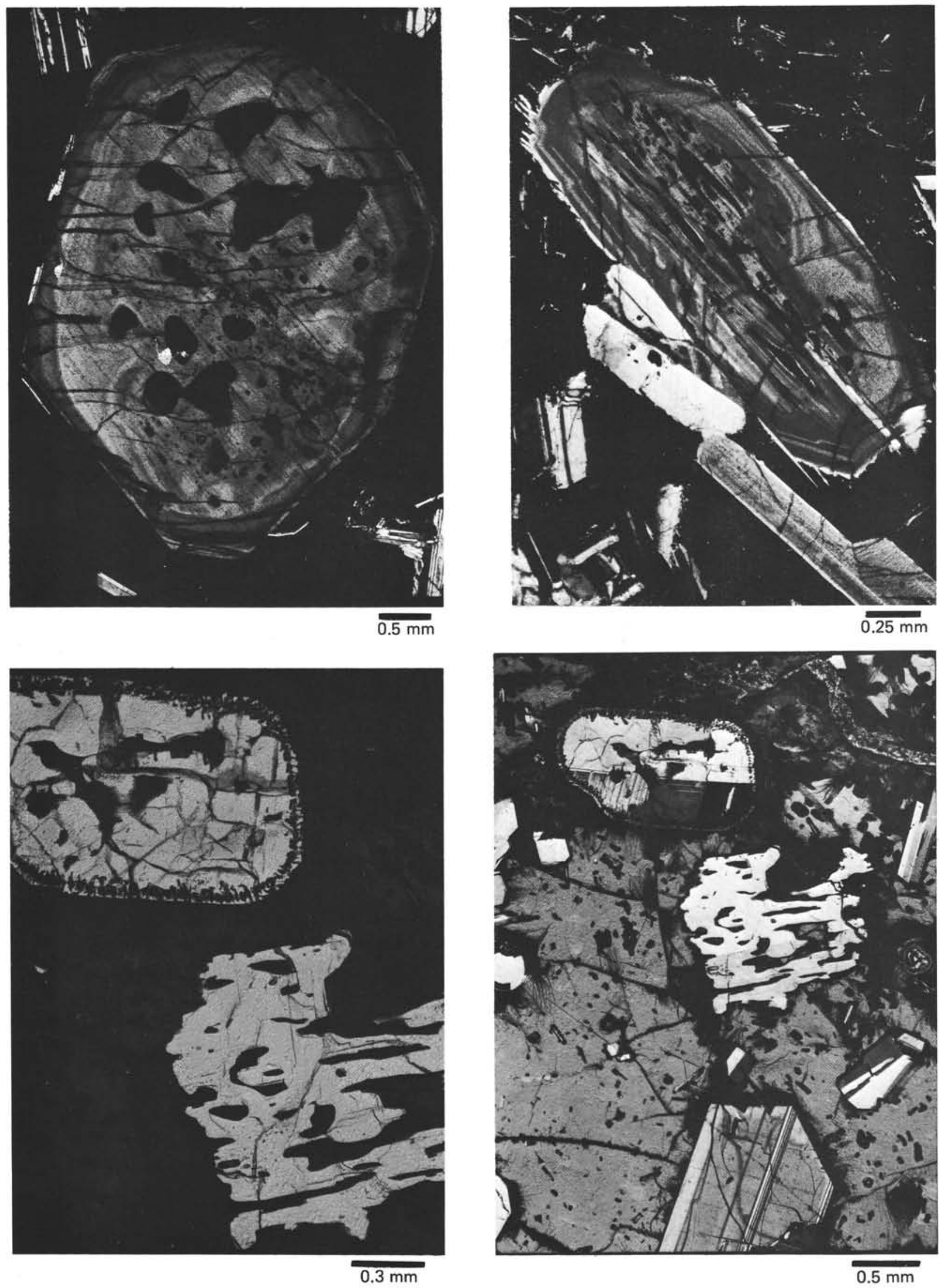


\section{PLATE 4}

Plagioclases

Figure 1

Figure 2

Figure 3

Figure 4
Bochum Sample 50; DSDP Sample 396B-5-2, 87-98 $\mathrm{cm}$. $\mathrm{O}=$ Olivine.

Bochum Sample 160; DSDP Sample 396B-8-3, 25-30 $\mathrm{cm}$.

Bochum Sample 400; DSDP Sample 396B-14-1, $121-127 \mathrm{~cm}$.

Bochum Sample 780; DSDP Sample 396B-18-1, $22-27 \mathrm{~cm}$. 


\section{PLATE 4}

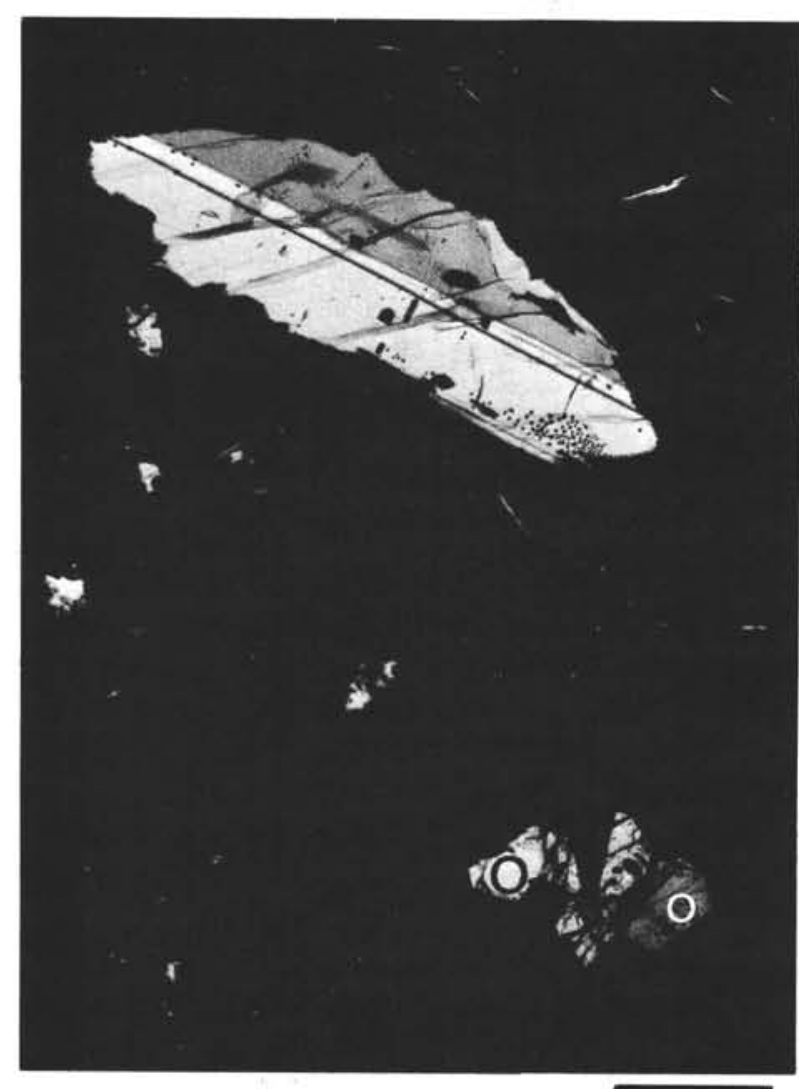

$0.5 \mathrm{~mm}$

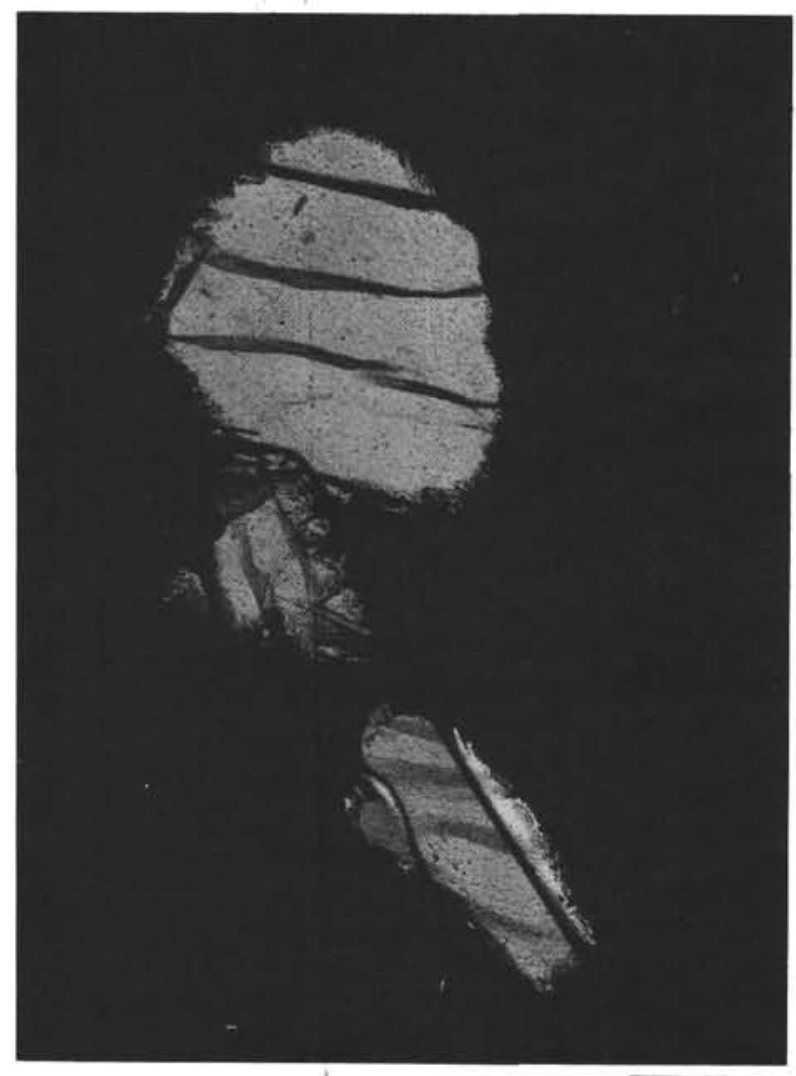

$0.25 \mathrm{~mm}$
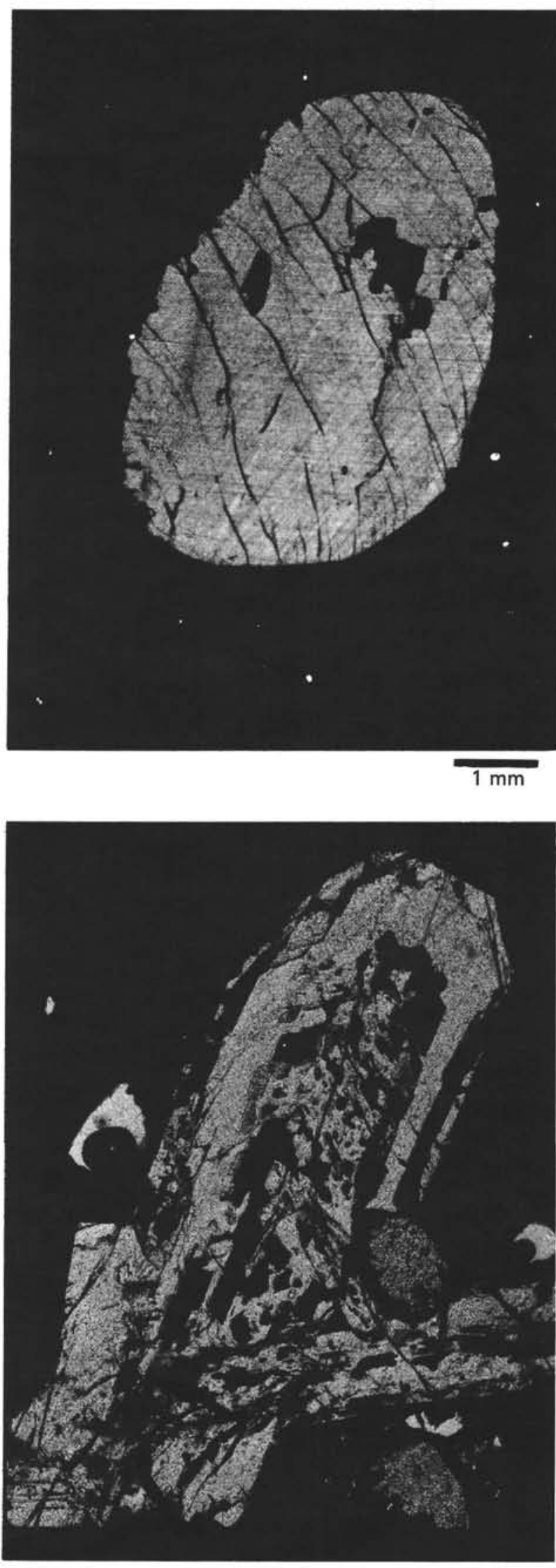

$0.3 \mathrm{~mm}$ 


\section{PLATE 5}

Olivines

Figure 1

Figure 2

Figure 3

Figure 4
Bochum Sample 860/870; DSDP Sample 396B-20-1, $70-80 \mathrm{~cm}$.

Bochum Sample 260; DSDP Sample 396B-11-2, $27-33 \mathrm{~cm}$. $\mathrm{O}=$ Olivine.

Bochum Sample 860/870; DSDP Sample 396B-20-1, $70-80 \mathrm{~cm}$.

Bochum Sample 1370; DSDP Sample 396B-32-1, $59-62 \mathrm{~cm}$. 
PLATE 5
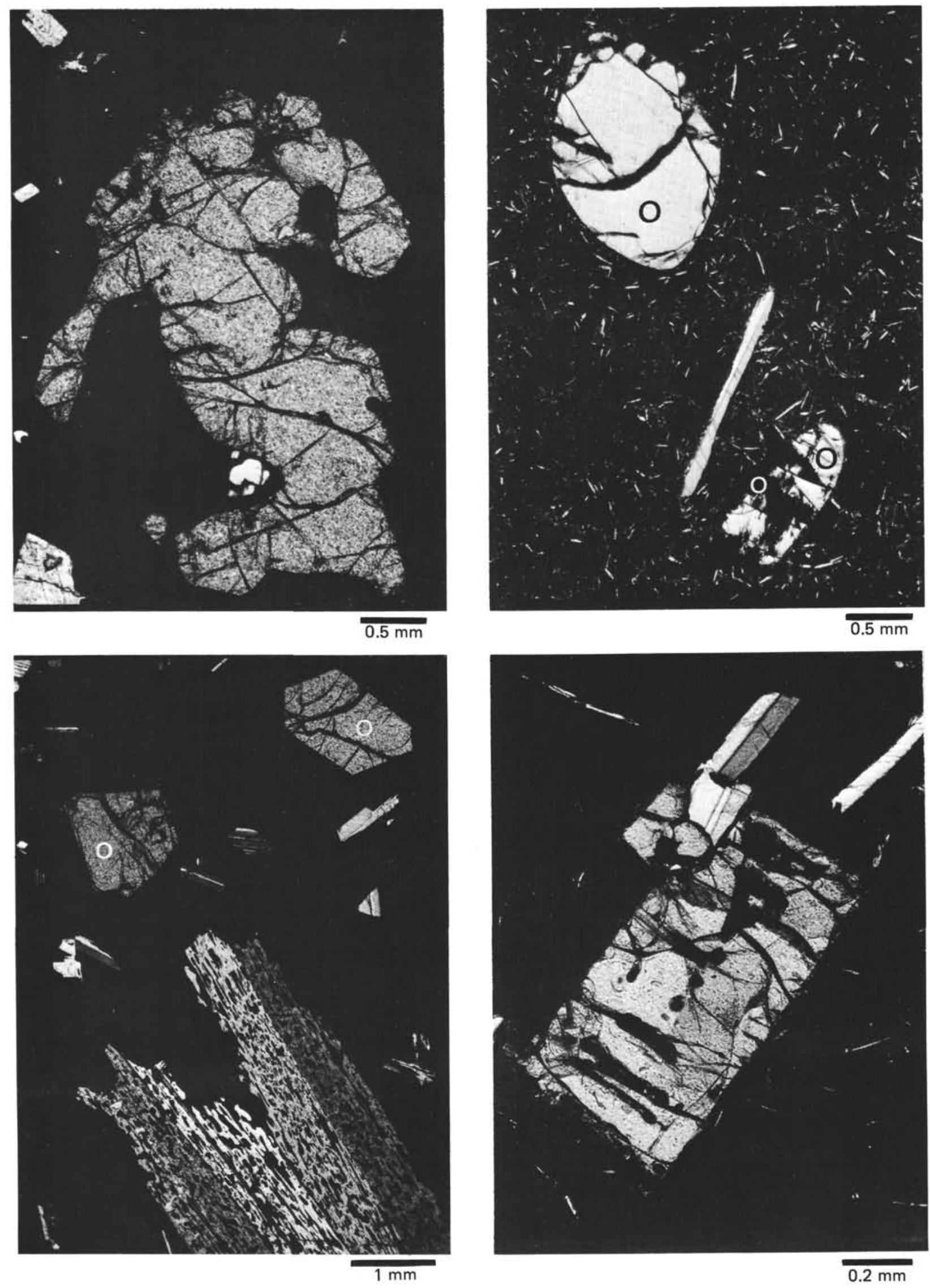